\title{
CO DRUGI DZIEŃ WERNISAŻ. POLSKIE WYDARZENIA ARTYSTYCZNE W WIELKIEJ BRYTANII W ROKU 1959
}

\author{
Mirosław A. SUPRUNIUK (Toruń)
}

Dorobek emigracji polskiej XX wieku, we wszystkich dziedzinach kultury, najwcześniej zainteresował literaturoznawców, historyków książki i prasy oraz historyków myśli politycznej. Liczba publikacji na temat tych zagadnień (często o dużej wartości poznawczej) jest imponująca; w rezultacie wiele nazwisk, nazw i wydarzeń ocalono od zapomnienia i utrwalono w podręcznikach. Trudno dziś wyobrazić sobie studia nad współczesną polską prozą, eseistyką czy poezją bez twórczości pisarzy takich jak Czesław Miłosz, Witold Gombrowicz, Jerzy Stempowski, Jerzy Pietrkiewicz, Kazimierz Wierzyński, Jan Lechoń, Józef Mackiewicz, Zofia Romanowiczowa czy Marian Hemar. Nie sposób mówić o XX-wiecznej ideologii niepodległościowej bez analizy koncepcji politycznych kręgu paryskiego Instytutu Literackiego, ugrupowań i partii wchodzących w skład rządu emigracyjnego w Londynie czy Rozgłośni Polskiej Radia Wolna Europa, a nazwiska księgarzy, wydawców i redaktorów takich jak Jerzy Giedroyc, Mieczysław Grydzewski, Zofia Hertz, Stefania Kossowska, Bolesław Wierzbiański, czy zmarły niedawno Kazimierz Romanowicz, dobrze znane są nie tylko badaczom emigracji. Działalność Polaków rozrzuconych po świecie, w różnych dziedzinach kultury, z mniejszymi lub większymi oporami, przedziera się także do świadomości historyków nauki, teatrologów, a nawet muzykologów. I wydaje się, że jedynie historycy sztuki wciąż mają kłopot z przyswojeniem nauce nie tylko nazwisk artystów plastyków żyjących i tworzących poza Polską, ale przede wszystkim z akceptacją faktu istnienia polskiej sztuki na świecie i jej dorobku.

Tymczasem niemal wszystko, co powstało w sztukach plastycznych oryginalnego i wartościowego w kulturze polskiej w XX wieku stworzone zostało poza granicami Polski. Celowo nie używam określenia „na emigracji”. Z dwóch powodów: po pierwsze, ponieważ do roku 1939 artyści najczęściej wyjeżdżali za granicę uczyć się, doskonalić warsztat lub poznawać nowe kierunki artystyczne, bez zamiaru pozostania poza 
Polską na stałe i zrywania z krajem jakichkolwiek kontaktów. To, że przebywali za granicą dłużej, czasem całe życie, wynikało z tak wielu różnych, indywidualnych powodów, że jakiekolwiek uogólnienie nie znajduje uzasadnienia. Wszystko co stworzyli było, co prawda, związane z dłuższym ich pobytem w oddaleniu od kraju, ale równocześnie — jeżeli tylko chcieli — było przed 1939 rokiem w Polsce mniej lub więcej znane za sprawą prasy, radia i działalności wystawienniczej. Drugi powód unikania określenia „,na emigracji” wynika z tego, że dla wielu artystów plastyków także w okresie po roku 1945 pozostanie na obczyźnie nie było automatycznie związane z brakiem kontaktu z krajowymi muzeami i galeriami. Emigracja polityczna, niezłomna w krytycznej ocenie wydarzeń za żelazną kurtyną i niechętna jakiejkolwiek współpracy z krajowymi instytucjami, potrafiła być zadziwiająco tolerancyjna w stosunku do artystów plastyków odwiedzających Polskę z wystawami. Podróże do Polski polityków, wojskowych, pisarzy, dziennikarzy, a często także ludzi nauki, uważane były za postępowanie naganne, jednak wyjazdy i wystawy plastyków były dopuszczalne i nie powodowały anatemy. Marek Żuławski, który przywiózł do Warszawy w 1946 roku swoje obrazy (i bywał w Polsce także w latach 50. i 80.), a wcześniej i później publikował w prasie krajowej szkice historyczne, nie doświadczył szykan z tego powodu. Podobnie inni artyści plastycy. Kiedy w latach odwilży 1957-1959 kilku malarzy zgodziło się na wystawy w Polsce — wśród nich: Józef Czapski, Marek Żuławski, Marian Kościałkowski - postępowanie ich, a nawet wyjazdy, także nie zostały uznane za zdradę niepisanych zasad funkcjonowania emigracyjnego państwa na wygnaniu. Podobnie realizacje ścienne Stefana Knappa dla Uniwersytetu Mikołaja Kopernika czy dla Planetarium w Olsztynie, powstałe w latach 70., czy jego wystawa w 1974 roku w „Zachęcie", oraz przede wszystkim krajowe ekspozycje Feliksa Topolskiego, nie powodowały „emigracyjnego” bojkotu tych artystów w Londynie czy Paryżu ${ }^{1}$. Przeciwnie, artykuły $\mathrm{w}$ prasie emigracyjnej sugerowały swego rodzaju dumę z docenienia emigranta w kraju. Nikt też nie miał żalu do Halimy Nałęcz i Mateusza Grabowskiego, że swoje kolekcje sztuki gromadzone w Londynie w galeriach podarowali do krajowych muzeów w Warszawie, Łodzi i Gdańsku. Uznano to za naturalne i potrzebne wzbogacanie zbiorów narodowych ${ }^{2}$.

„Sztuka polska na świecie”, zarówno w rozumieniu biografii artystów, ich dorobku, jak i życia artystycznego, to pojęcie złożone, i dla każdego kraju, w którym żyli Polacy, znaczące co innego. W odniesieniu do wielu artystów plastyków określenie „emigrant polityczny” ma uzasadnienie. I zgodzić się trzeba, że obok malarzy, których dzieła sztuki docierały do Polski, mieszkali na świecie plastycy, dla których galerie i muzea krajowe były niedostępne z przyczyn pozaartystycznych. Miejsce zamieszkania artysty miało tu pewne znaczenie. O ile bowiem środowiska polskich artystów plastyków we Francji w pierwszej połowie XX wieku (a nawet później) są dość dobrze opisane, co da się wytłumaczyć ,apolitycznością” polsko-francuskich środowisk artystycznych i obecnością ich dorobku w Polsce przed rokiem 1990, o tyle wciąż niewiele wiemy o emigracyjnym artystycznym ,polskim” Londynie, o działalności malarzy i rzeźbiarzy polskich w Stanach Zjednoczonych, Kanadzie, Ameryce Południowej czy Australii. Ten stan wiedzy wynika $\mathrm{z}$ wieloletnich zaniedbań podyktowanych uwarunkowaniami politycznymi i niedostatecznym wykształceniem historyków sztuki, dla których wydaje się nie być ciągłości ani łączności kultury polskiej tworzonej w Polsce

${ }^{1}$ M. A. Supruniuk, „Trwatość i ptynność”. Sztuka polska w Wielkiej Brytanii w XX wieku wstęp do opisu, Archiwum Emigracji. Studia - Szkice - Dokumenty 2006 z. 1-2(7-8), s. 127-159.

2 Por. na ten temat: J. W. Sienkiewicz, Halima Natęcz, Toruń 2007, s. 35-38. 
w XX wieku z tą, której twórcami byli polscy emigranci na świecie. Niech ilustracją tej oceny będzie wydany w roku 1992 trzeci tom seryjnego wydawnictwa Instytutu Sztuki PAN Polskie życie artystyczne, obejmujący lata 1945-1960, w którym pominięto cały dorobek artystyczny polskiej emigracji ${ }^{3}$. Powodów tego wykluczenia nie wyjaśnia ani przyjęta metodologia, ani Uwagi ogólne redaktora, Aleksandra Wojciechowskiego, ani fakt że książka przygotowana została w roku 1980 i jest jedynie pierwszym tomem dużego opracowania (tom drugi zawierać ma podobno „diariusz ważniejszych wydarzeń” życia artystycznego, lecz do tej pory nie ukazał się) ${ }^{4}$. Wszelako, lektura nazwisk 45 autorów książki, wśród których są najgłośniejsi współcześni historycy i krytycy sztuki w Polsce pozwala zrozumieć, dlaczego kolejne pokolenia wychowanków wyższych uczelni i instytutów naukowych nie dostrzegają ogromnego dorobku polskiego wychodźstwa w dziedzinie sztuk plastycznych.

W tym kontekście wydaje się naturalne, że dopiero po 1990 roku możliwe stało się studiowanie biografii i twórczości poszczególnych artystów emigrantów oraz oglądanie ich dorobku artystycznego, tylko w niewielkim stopniu gromadzonego w polskich muzeach w okresie Polski Ludowej. Owa „możliwość” nie oznaczała jednak w praktyce wyraźnego wzrostu zainteresowania ${ }^{5}$. Wystawa „Jesteśmy”, zorganizowana w Zachęcie w roku 1991 przez Elżbietę Dzikowską i Wiesławę Wierzchowską, na której pokazano prace żyjących wówczas malarzy i rzeźbiarzy polskich tworzących poza Polską i towarzyszący jej obszerny katalog, zawierający biogramy plastyków oraz barwne reprodukcje prac, nie stały się początkiem „powrotu” tych artystów do świadomości historyków sztuki ${ }^{6}$. Żadna instytucja muzealna w Polsce nie podjęła wówczas trudu pozyskiwania dzieł sztuki i dokumentów archiwalnych po tysiącach polskich artystów plastyków żyjących i tworzących na obczyźnie. Nie znalazły swojego historyka ani żadna emigracyjna instytucja zarządzająca sztuką, ani polskie życie artystyczne na emigracji. Wszelkie prace i publikacje powstałe na początku lat 90 ., w tym próby przyswojenia dorobku plastycznego ,polskiego” Londynu przez krytykę sztuki w Polsce, były najczęściej swobodnym streszczeniem publikacji emigracyjnych, ilustrowanym przypadkowymi przykładami dzieł emigrantów ${ }^{7}$. Ważna i precedensowa konfe-

\footnotetext{
${ }^{3}$ Polskie życie artystyczne $w$ latach 1945-1960: grupy artystyczne, galerie, salony, kluby, stowarzyszenia twórcze, naukowe oraz instytucje badań nad sztuka, szkolnictwo, mecenat państwowy, spoteczne instytucje opieki nad sztuka, muzealnictwo, architektura, wzornictwo przemysłowe, czasopiśmiennictwo, praca zbiorowa pod red. A. Wojciechowskiego, Wrocław 1992.

${ }^{4}$ Tamże, s. 3.

${ }^{5}$ Stan badań po 1990 r. omówiony został w publikacjach: J. W. Sienkiewicz, Polskie galerie sztuki $w$ Londynie $w$ drugiej połowie XX wieku, Lublin-Londyn 2003, s. 11-34; M. A. Supruniuk, „Trwatość i ptynność”..., s. 127-159.

"Jesteśmy. Wystawa dziet artystów polskich tworzacych za granica, wrzesień-październik 1991, Warszawa 1991. Warto pamiętać, że oprócz ekspozycji w Zachęcie odbyło się wówczas kilka samodzielnych wystaw wzdłuż Traktu Królewskiego, w tym kilka z udziałem plastyków polskich z Anglii; w Kordegardzie, przy Krakowskim Przedmieściu, 6 września odbył się wernisaż wystawy zatytułowanej „Dziedzictwo”, na której zaprezentowano obrazy artystów zmarłych w Wielkiej Brytanii: Franciszki Themerson, Henryka Gotliba, Feliksa Topolskiego, Jankiela Adlera i Marka Żuławskiego. W kilku galeriach warszawskich pokazano indywidualne wystawy artystów biorących udział w ekspozycji „Jesteśmy”, z Anglii: Tadeusza Kopera i Aleksandra Żywa; por.: D. Kozińska, „Jesteśmy”, Tydzień Polski (dalej: TP) 1991 nr 37, s. 12; K. Kopcińska, Wrzesień w kulturze polskiej, TP $1991 \mathrm{nr}$ 38, s. 9-10.

${ }^{7}$ Por. np.: D. Wróblewska, Wokót Londynu, [w:] Między Polska a światem. Kultura emigracyjna po 1939 roku, pod red. M. Fik, Warszawa 1992, s. 301-304.
} 
rencja, zorganizowana w dniach 3-5 września 1991 roku, oraz publikacja Instytutu Sztuki PAN pt. Między Polska a światem. Kultura emigracyjna po 1939 roku, w której sztuce polskiej w Wielkiej Brytanii poświęcono wiele miejsca, nie znalazła kontynu$\mathrm{acji}^{8}$. Odnosi się nawet wrażenie, że — pomijając dysproporcję pomiędzy liczbą wystawiających w Polsce, a liczbą artystów uprawiających swój zawód w Wielkiej Brytanii, Francji czy Stanach Zjednoczonych (nasza wiedza jest dziś o wiele większa) — że w okresie do roku 1990 malarze, rzeźbiarze czy graficy polscy mieszkający w Londynie byli w Polsce lepiej znani niż obecnie.

Należy jednak zwrócić uwagę na wypowiedź wspomnianego wyżej Aleksandra Wojciechowskiego, zmarłego w 2006 roku, kierownika ośrodka badań i dokumentacji plastyki współczesnej IS PAN do 1991 roku, który omawiając wystawę „Jesteśmy” powiedział:

Z własnego doświadczenia pragnę powiedzieć, że jako wieloletni organizator udziału Polski w wystawach międzynarodowych nie miałem możliwości — mimo usilnych starań — ze względu na stanowisko władz PRL, pokazania ani jednego artysty żyjącego poza krajem. [...] Mówimy o działalności twórców polskich poza granicami kraju. Staramy się analizować ich osiągnięcia. Zastanawiamy się nad ich pozycją na światowej giełdzie kultury. Cieszą nas sukcesy, smucą stracone szanse [...]. W odwrotną stronę nie są prowadzone niemal żadne badania. Mam tu na myśli problem wkładu artystów polskich lub polskiego pochodzenia w kulturę kraju, który aktualnie stał się ich nową ojczyzną. Inaczej mówiąc: nie braliśmy niczego za darmo, również dawaliśmy wiele i szczodrze. Nie jest to moja narodowa megalomania, lecz w zakresie szeroko rozumianej humanistyki dopominam się o oczywistą prawdę. [...] prócz niezbędnej wymiany dzieł sztuki i bezpośrednich kontaktów z artystami żyjącymi za granicą, powinniśmy podjąć trud oceny ich niewątpliwych zasług dla kultury światowej. Badania takie moglibyśmy prowadzić i poprzez nasze zagraniczne instytuty kultury i przez powołanie odpowiednich zespołów działających na wyższych uczelniach i w Polskiej Akademii Nauk. [...] na to nie potrzeba wielkich funduszy, lecz kilku kompetentnych zapaleńców ${ }^{9}$.

\section{Życie artystyczne polskiego Londynu w roku 1959}

Musiało minąć kilka lat od wspomnianej sesji IS PAN, by w Polsce dostrzeżono potrzebę „opieki” nad spuścizną sztuki polskiej na świecie, w szczególności sztuki polskiej w Wielkiej Brytanii, i konieczność podjęcia studiów uniwersyteckich nad tym ważnym dla kultury polskiej dorobkiem. To, co w ostatnich latach ukazało się drukiem jest zasługą „,zapaleńców” pracujących w Lublinie i Toruniu ${ }^{10}$. Powstałe po 1993 roku opracowania i publikacje, których autorami, opiekunami naukowymi lub redaktorami byli: Jan W. Sienkiewicz, Krzysztof Pomian oraz Mirosław A. Supruniuk, to nadal zaledwie kilkanaście prac magisterskich, kilka książek oraz garść artykułów, które opisują poszczególne elementy polskiego życia artystycznego na emigracji — głównie w Londynie. To wciąż zbyt mało, by pokusić się o jakieś wartościowanie i tworzenie zbiorowego opisu polskiego życia artystycznego w Wielkiej Brytanii. Na uwagę badacza zasługuje bowiem wszystko, co można zawrzeć w pojęciu ,życie artystyczne”: biografie poszczególnych artystów plastyków i ich aktywność twórcza, działalność

${ }^{8}$ I. Grzesiuk-Olszewska, Rzeźbiarze polscy w Londynie, [w:] Między Polska a światem..., s. 110-116; J. Kilian, Feliks Topolski - kronikarz XX wieku, tamże, s. 177-184; I. Dżurkowska-Kossowska, P. Paszkiewicz, Marian Bohusz-Szyszko jako wspótorganizator polskiego życia artystycznego na obczyźnie, tamże, s. 233-240; D. Wróblewska, Wokót Londynu, tamże, s. 300-304.

${ }_{9}^{9}$ A. Wojciechowski, Co dalej, [w:] Między Polska a światem..., s. 308.

${ }^{10}$ J. W. Sienkiewicz, Polskie galerie sztuki w Londynie..., s. 17-34. 
grup artystycznych, galerii, klubów i stowarzyszeń twórczych, instytucji naukowych i szkół artystycznych, ale też kolekcjonerstwo, muzealnictwo, edytorstwo artystyczne, architektura, wzornictwo przemysłowe, czasopiśmiennictwo, krytyka sztuki itp. Z tego ogromnego obszaru doczekaliśmy się jedynie opracowania poświęconego polskim galeriom sztuki w Londynie oraz kilku monografii dorobku artystycznego malarzy ${ }^{11}$, a także krytycznego wydania tekstów na temat polskiej sztuki emigracyjnej w Wielkiej Brytanii $^{12}$.

Biorąc pod uwagę użyteczność i wartość poznawczą pierwszych dwóch tomów Polskiego życia artystycznego do roku 1939, przygotowanych przez IS PAN, w Toruniu, podjęto starania by, przy wykorzystaniu schematu wydawnictwa Instytutu Sztuki, opisać wydarzenia „polskiego życia artystycznego w Wielkiej Brytanii w XX wieku”. Skupienie się na stenograficznym spisie polskich wystaw i wydarzeń artystycznych, oraz takich, w których brali udział polscy plastycy lub były wystawiane przedmioty z Polski, wydało się niewystarczające. Dzieje sztuki uczą, że aktywność twórcza nawet wielkich artystów podlega różnym wahaniom w czasie. Podążanie za modą i aktualnymi prądami w sztuce, opinia krytyków sztuki i kupujących powodują, że wystawy indywidualne jakiegoś malarza czasem organizowane są kilka razy w roku, a innym razem przez cały rok nie potrafi on zgromadzić dość dobrych prac, by pochwalić się nimi przed widzami. Inaczej jest, gdy artysta ma podpisaną umowę z ,własną" galerią, która to umowa zobowiązuje go do dostarczania określonej liczby prac każdego roku, inaczej, gdy „niezależność” artysty lub mniejsza popularność każe mu szukać coraz to nowych miejsc ekspozycji. Dla wielkiej liczby wydarzeń artystycznych w Polsce lat międzywojennych i w PRL, autorzy Życia zmuszeni byli zastosować selekcję materiału i wybrać do opisu jedynie wydarzenia, w których brali udział artyści o znaczących nazwiskach. Wymóg ten nie mógł być zastosowany w odniesieniu do „polskiego” Londynu z tego względu, że określenie tego, kto był „znaczącym artystą” można zastosować jedynie do grup rozpoznanych i krytycznie opisanych. Dlatego wydawało się konieczne odnotowanie wszystkich, bez względu na „ważność”, wydarzeń życia artystycznego. Konieczne było także poszerzenie opisu o kontekst odbioru — recenzje i noty prasowe; ich liczba i miejsce publikacji, a także nazwisko autora krytyki, wydają się być również jednym z czynników tworzących w zamkniętej społeczności ,,polskiego” Londynu, ,życie artystyczne”, a dla czytelnika ważną informacją o znaczeniu konkretnego wydarzenia w życiu społeczno-kulturalnym polskiej diaspory. Można bowiem zakładać, że o ile wychodzące w Londynie „Dziennik Polski”, „Oblicze Tygodnia” czy „Gazeta Niedzielna” starały się zamieszczać informacje o niemal wszystkich wydarzeniach, o tyle czasopisma takie jak „Wiadomości”, a zwłaszcza prasa brytyjska odnotowywały wydarzenia najważniejsze. Można także przyjąć, że krytycy tacy jak Stefania Zahorska, Marian Bohusz-Szyszko, Zygmunt Turkiewicz czy Stanisław Frenkiel podejmowali się dłuższych recenzji tylko wystaw ciekawszych i jedynie ekspozycje najwybitniejszych artystów znajdowały miejsce w audycjach Marka Żuławskiego w BBC.

Opis dotyczy jednego roku. Zaledwie jednego roku, ale dla kultury polskiej w Wielkiej Brytanii ze wszech miar szczególnego. W 1959 roku miało miejsce kilka wydarzeń, które na wiele lat ukształtowały polskie życie artystyczne nad Tamizą.

${ }^{11}$ J. W. Sienkiewicz, Polskie galerie sztuki w Londynie; tegoż, Marian Bohusz-Szyszko. Życie i twórczość 1901-1995, Lublin 1995; tenże, Halima Natęcz; tenże, Ryszard Demel. W drodze do tajemnicy światta, Torun 2010.

${ }^{12}$ Sztuka polska w Wielkiej Brytanii 1940-2000. Antologia, wybrał, przygotował do druku i wstępem opatrzył M. A. Supruniuk, Toruń 2006. 
Pierwszym z nich i w konsekwencji najważniejszym było powstanie Grabowski Gallery (przy 84 Sloane Avenue SW3). Jej pomysłodawcą i założycielem był Mateusz Grabowski, aptekarz, który — być może pod wpływem sukcesów Drian Gallery, galerii Halimy Nałęcz — postanowił otworzyć w Londynie własną galerię sztuki współczesnej. Otwarta w lutym tego roku, stała się aż do późnych lat 70. najważniejszą polską galerią w Londynie i miejscem, w którym koncentrowało się życie organizacyjne polskich plastyków zrzeszonych w APA (Association of Polish Artists in Great Britain). Indywidualne wystawy „u Grabowskiego” mieli także artyści polscy: Marian BohuszSzyszko, Janina Baranowska, Marek Łączyński, Tadeusz Beutlich, Aleksander Werner, Tadeusz Koper, Tadeusz Znicz-Muszyński, Piotr Mleczko, Stanisław Frenkiel, Antoni Dobrowolski, Leon Piesowocki, Andrzej Bobrowski i Caziel ${ }^{13}$, a w ciągu 16 zaledwie lat działalności galeria zorganizowała ponad sto wystaw dla młodych artystów z całego świata ${ }^{14}$.

Powstanie polskiej galerii stało się także pretekstem do kilku interesujących inicjatyw wydawniczych. Pierwszą z nich był „Dodatek Ilustrowany” do „Oblicza Tygodnia”, który zamieszczając bogato ilustrowane recenzje z każdej wystawy w Galerii Grabowskiego, stał się swego rodzaju wstępem do nowej polskiej krytyki artystycznej w Londynie. Rok później Grabowski nawiązał współpracę z „Merkuriuszem Polskim — Życiem Akademickim” i rozpoczął wydawanie dodatku do pisma pn. „Młoda Sztuka”. Redaktorem dodatku, drukowanego - co zostało zaznaczone na stronie tytułowej - dzięki dotacji finansowej Grabowskiego, był Wojciech Mirzyński. I chociaż ukazało się zaledwie sześć numerów „Młodej Sztuki” w latach 1960-1963, pismo to na krótki moment stało się miejscem wymiany poglądów na sztukę autorów takich jak Marek Łączyński, Danuta Step, Stanisław Frenkiel, Bruno Kulczycki, Janina Baranowska, a nawet Zygmunt Turkiewicz i Marian Bohusz-Szyszko ${ }^{15}$.

Drugim wydarzeniem roku 1959, którego znaczenia nie sposób przecenić była dziesiąta rocznica działalności Grupy 49 i rocznicowa wystawa, ostatnia, jaką udało się zorganizować. W roku 1960 nie było już Grupy 49 — jedynego w pełni oryginalnego polskiego artystycznego ugrupowania na emigracji. Byli natomiast w pełni dojrzali, już niemłodzi artyści, dla których zbiorowa ekspozycja w Grabowski Gallery była swego rodzaju początkiem kariery. Ugrupowanie to tworzyli w różnych latach: Janina Baranowska, Tadeusz Beutlich, Andrzej Bobrowski, Marian Bohusz-Szyszko, Ryszard Demel, Antoni Dobrowolski, Kazimierz Dźwig, Mieczysław Chojko, Janusz Eichler, Marian Kościałkowski, Piotr Mleczko, Tadeusz Znicz-Muszyński, Leon Piesowocki, Stefan Starzyński i Aleksander Werner. Za wyjątkiem mentora grupy - Bohusza-Szyszko oraz nieco starszego od kolegów Mariana Kościałkowskiego, wszyscy ukończyli szkoły we Włoszech i Wielkiej Brytanii.

Cyklem ważnych wydarzeń tego roku, choć ich właściwa ocena wymagałaby szczegółowych studiów w okresie poprzedzającym rok 1959 i w latach następnych, nazwałbym także działalność popularyzatorską Polskiej YMCA oraz cykl wykładów i wycieczek artystycznych Mariana Bohusza-Szyszko. Łatwo jednak dostrzec, że sala Ogniska Polskiej YMCA, przy 46/47 Kensington Gdns Square w Londynie, stała się w roku 1959 (biorąc pod uwagę liczbę wydarzeń), najważniejszym miejscem polskiego, bardzo różnorodnego, życia artystycznego w Londynie. Przez cały rok 1959 Polska

${ }^{13}$ S. Frenkiel, Pożegnanie Galerii Grabowskiego, [w:] tegoż, Kożuchy w chmurach i inne eseje o sztuce, wstęp i wybór J. Koźmiński, Torun 1998, s. 224-228.

${ }_{14}^{14}$ J. W. Sienkiewicz, Polskie galerie sztuki w Londynie..., pass.

${ }^{15}$ M. A. Supruniuk, Sztuka polska w Wielkiej Brytanii 1940-2000. Źródta i stan badań, [w:] Sztuka polska w Wielkiej Brytanii 1940-2000, s. 9. 
YMCA organizowała swego rodzaju ,wycieczki artystyczne” do muzeów, galerii i zabytkowych budynków w Londynie i okolicach, połączone z wykładem lub prelekcją prof. Mariana Bohusza-Szyszko. Tematy i miejsca wycieczki wymyślał, jak się wydaje, sam M. Bohusz-Szyszko. Odbywały się one co tydzień i ich atrakcyjność związana była także z faktem, że organizacja wydarzenia przez Polską YMCA pozwalała na zakup tańszych (ulgowych) biletów i bardziej profesjonalne zwiedzanie muzeów angielskich. Pierwsza wycieczka w roku 1959 wyruszyła do Victoria \& Albert Museum, a kolejne wiodły do British Museum, National Gallery, Tate Gallery oraz prywatnych i publicznych kolekcji w okolicy Londynu ${ }^{16}$.

Ostatnim wydarzeniem roku 1959, na które należy zwrócić uwagę, są audycje radiowe Marka Żuławskiego. Z tym jednak zastrzeżeniem, że mowa tu o cyklu wydarzeń, których zasięgu oddziaływania nie jesteśmy w stanie ocenić głównie ze względu na brak jakichkolwiek danych o słuchaczach polskich audycji BBC. Wiemy skądinąd, że w następnych latach audycje o sztuce w radiu brytyjskim mieli także Stanisław Frenkiel oraz sporadycznie inni redaktorzy, np. Bolesław Taborski przeprowadzający rozmowy z artystami plastykami. Audycje Marka Żuławskiego nie zachowały się w archiwum BBC, a jedynie w prywatnych materiałach malarza. Niestety, spuścizna nie jest kompletna, stąd brak pewności, jak długo (od kiedy) audycje te były realizowane i czy były poświęcone wyłącznie sztuce. Wyraźnie jednak widać, że omawianie polskich wystaw i polskich wydarzeń artystycznych nie było najważniejszym zadaniem cyklu „Round the Galleries”.

Sztuka polska w Wielkiej Brytanii, jak zaznaczyłem to już w poprzednich publikacjach, obejmuje malarstwo, rzeźbę, grafikę, rysunek, ilustrację książkową, grafikę użytkową, architekturę oraz fotografię - te ostatnie zwłaszcza wówczas, gdy biorą udział w ekspozycjach lub wydarzeniach organizacyjnych. Definiując dla potrzeb niniejszej pracy pojęcie ,życie artystyczne”, skupiono się, analogicznie do publikacji Polskie życie artystyczne w latach 1890-1914, wydanej pod red. Aleksandra Wojciechowskiego w 1967 roku, na tym wszystkim, co dotyczy w pierwszym rzędzie kontaktów artysty z odbiorcą. Dlatego najważniejsze są tu wystawy. W wypadku ,polskiego” Londynu rozróżniliśmy wystawy, w których uczestniczyli Polacy (bez względu na miejsce ekspozycji - polskie emigracyjne, polskie „reżymowe” i obce) oraz wystawy w polskich galeriach (Drian Gallery, Grabowski Gallery, a później także Cassel Gallery, Centaur Gallery, czy POSK Gallery) i w pomieszczeniach adaptowanych na potrzeby wystawiennicze (Ognisko Polskiej YMCA, biblioteki, kluby, kawiarnie, lokale związkowe itp.), w których organizowane były ekspozycje artystów plastyków niepolskich. Ponieważ wydarzenia te organizowały i gromadziły Polaków jako odbiorców znalazły się w obszarze naszego zainteresowania. Notując wystawy Polaków wzięto pod uwagę zarówno artystów mieszkających poza Polską, jak i gości z Polski (lub ich wystawy), którzy przez cały okres XX wieku odwiedzali Wielką Brytanię. Spisy zawierają ponadto informacje o prezentacji wystaw nieprofesjonalnych (np. dziecięcych), historycznych, przygotowanych z polskich zbiorów muzealnych, a dotyczących artystów zmarłych przed XX stuleciem, bądź też ekspozycji przedmiotów kultury materialnej, np. mebli artystycznych, kultury ludowej, strojów czy tkactwa.

W pojęciu ,polskie życie artystyczne” zmieściły się także:

- wystawy para-artystyczne, np. filatelistyczne, rzemiosła, książek, przedmiotów pochodzących z okresu wojny itd.;

\footnotetext{
${ }^{16}$ Odczyty i wystawy, Dziennik Polski i Dziennik Żołnierza (dalej: DPDŻ) 3.01.1959, s. 4.
} 
- pół-publiczne i czasem prywatne prezentacje dzieł sztuki (w mieszkaniach lub studio, np. w akcji ,otwarte studio”), odsłonięcia pomników, ołtarzy itp.;

- spotkania towarzyskie polskich artystów z udziałem publiczności, wycieczki ,artystyczne", prelekcje i wystąpienia publiczne — bez względu na miejsce;

- spotkania towarzyskie niepolskich artystów z udziałem polskiej publiczności i w polskich lokalach, prelekcje i wystąpienia publiczne dla Polaków;

- działalność polskich szkół artystycznych i studiów brytyjskich tworzonych dla polskich studentów (zwłaszcza w latach tużpowojennych - mowa tu np. o Sir John Cass' College of Art and Craft w Londynie) czy studiów architektonicznych;

- otwarcia nowych pracowni-studio polskich artystów lub polsko-brytyjskich;

- polskie czasopisma poświęcone sztuce oraz biuletyny organizacji artystycznych, takich jak „Biuletyn Stowarzyszenia Fotografików Polskich”, „Młoda Sztuka”, „Oficyna Poetów” itp.;

- duże publikacje na temat sztuki w znaczących polskich czasopismach społeczno-politycznych i literackich — tu szczególnie wywiady i rozmowy z artystami;

- publikacje autorów polskich lub artykuły o polskich artystach w znaczących czasopismach brytyjskich, np. recenzje wystaw, okładki, duże wkładki z ilustracjami, zeszyty specjalne itp.;

- audycje radiowe w BBC w języku polskim poświęcone sztuce oraz w języku angielskim realizowane przez Polaków;

- publikacje ilustrowane przez Polaków bez względu na język książki;

- książki na temat sztuki polskiej wydane w Wielkiej Brytanii lub książki napisane przez plastyków, np. autobiografie, wspomnienia, dzienniki itp.;

- albumy, teki grafik i rysunków, monografie itd.;

- publikacje brytyjskie, np. słowniki, encyklopedie, w których mowa o polskich plastykach;

- $\quad$ angielskie, polskie lub międzynarodowe sukcesy artystyczne Polaków z Wielkiej Brytanii, np. nagrody na konkursach, olimpiadach, członkostwa w organizacjach i stowarzyszeniach;

- zgony plastyków polskich związanych z Wielką Brytanią;

Opisując polskie życie artystyczne w Wielkiej Brytanii brałem pod uwagę także wystawy Polaków z Wielkiej Brytanii realizowane poza wyspami, np. w Polsce, Niemczech, Francji, Kanadzie, Stanach Zjednoczonych itd.

Najważniejszym źródłem dla badania polskiego życia artystycznego w Wielkiej Brytanii jest polska prasa emigracyjna i ukazujące się w Londynie czasopisma wydawane przez polskie placówki dyplomatyczne PRL. W XX wieku ukazywało się na wyspach ponad tysiąc tytułów czasopism i biuletynów, przy czym większa ich część to periodyki wydawane nie dłużej niż kilka lat. Czasopism i gazet drukowanych dłużej było nie więcej niż kilkadziesiąt, w tym na uwagę zasługują przede wszystkim: „Dziennik Polski i Dziennik Żołnierza”, „Jutro Polski”, „Gazeta Niedzielna”, „, Orzeł Biały”, „Życie”, „Wiadomości”, „Kronika”, „Oblicze Tygodnia”, „Fotorama”, „Wiadomości POSK”, „Kontynenty” (i pozostałe mutacje tego pisma) i wspomniany wyżej „Biuletyn Stowarzyszenia Fotografików Polskich”. Większość z nich mogła notować wydarzenia ze świata sztuki, które wyżej określiłem jako interesujące. Były to przede wszystkim ogłoszenia o wystawach i ich recenzje, nekrologi i szkice biograficzne pisane post mortem, szkice historyczne, ale też notatki odredakcyjne informujące np. o zakupie jakiegoś polskiego dzieła sztuki do brytyjskiego muzeum, galerii czy kolekcji. W prasie 
polskiej ukazywały się również reprodukcje (a sporadycznie także oryginały — linoryty i drzeworyty na okładkach lub wkładkach) dzieł sztuki, także fotografie z wystaw, wizerunki artystów, wnętrza ich pracowni itp. Bardzo często były to również ilustracje dopełniające teksty literackie lub winiety — w obu wypadkach świadczyły o pełniejszej współpracy plastyka z jakimś tytułem. Należy zaznaczyć, że sporadycznie, również w emigracyjnych czasopismach wydawanych poza Wielką Brytanią, publikowane były informacje na temat polskich wystaw w Londynie czy sukcesów polsko-angielskich artystów plastyków, zwłaszcza, gdy były to sukcesy międzynarodowe. Wśród periodyków kontynentalnych, nieobojętnych na wydarzenia polskiego życia artystycznego w Anglii, wymienić należy paryską „Kulturę”, która głównie piórem Zygmunta Turkiewicza zamieszczała sprawozdania $\mathrm{z}$ wystaw londyńskich, a także „Horyzonty” ukazujące się również w Paryżu. Pewną wartość dokumentacyjną posiada także prasa polska wychodząca w kraju. Znajdują się w niej informacje na temat wystaw krajowych oraz teksty biograficzne i krytyczno-historyczne. Tego rodzaju teksty ukazywały się w różnych latach w „Przeglądzie Artystycznym”, „Sztuce”, „Kuźnicy”, „Tygodniku Powszechnym”, „Panoramie Polskiej”, „Świecie”, „Widnokręgach”, „Przemianach”, „Świecie i Polsce”, „Zebrze”, „Razem” oraz przede wszystkim w periodykach drugiego obiegu. Obok pism informacyjnych były też propagandowe, których głównym celem było tworzenie pozytywnego medialnego obrazu Polski Ludowej na świecie. W tego rodzaju czasopismach pojawiały się teksty na temat emigracyjnych plastyków o ile byli oni „obojętni politycznie”, bądź też godzili się na wystawy w Polsce. Najważniejszym pismem tego rodzaju był miesięcznik „Polska”, wychodzący także w innych edycjach językowych jako „Poland”, „Pologne”, „Polonia” i „Polen”, poza tym były to pisma sprzedawane lub rozsyłane poza Polską: „Polish Perspectives”, „Stolica”, „Przekrój”, „7 dni w Polsce” itp.

Ogromną wartość dokumentacyjną posiada prasa brytyjska, tu głównie miesięczniki poświęcone wydarzeniom artystycznym: „The Studio”, „The Arts Review”, „Apollo”, „The Architects”, „International Art”, „Art News and Review”, a także dodatki artystyczne do dzienników „The Guardian”, „The Times” itp. Czasopisma i gazety brytyjskie zamieszczały przede wszystkim recenzje i omówienia wystaw w galeriach niepolskich, ogłoszenia o wystawach, noty o eksponowanych obiektach, ale też np. nekrologi. Sporadycznie ukazywały się w nich reprodukcje dzieł polskich malarzy. W wypadku artystów plastyków luźno (lub w ogóle) związanych ze środowiskiem polskiej emigracji, czasopisma te stanowią główne, a czasem jedyne źródło informacji o ich wystawach. Dotyczy to nazwisk takich jak Bernard Meninsky, Jacob Epstein, Stanisława de Karlowski, a nawet Józef Herman. Wraz z pojawieniem się polskich galerii, takich jak Drian Gallery i Grabowski Gallery, niektóre z wystaw — zwłaszcza te dotyczące sztuki awangardowej — także znajdowały omówienie w prasie brytyjskiej.

Nie sposób przecenić wartości publikacji książkowych, polskich i angielskich, które możemy podzielić na trzy kategorie:

- $\quad$ katalogi i foldery wystaw — te są źródłem najpierwszym i najpewniejszym. Niemal każda wystawa w galeriach polskich posiadała mniejszy lub większy dokument graficzny upamiętniający ekspozycję. Obok ciekawych artystycznie katalogów Drian Galleries, znajdujemy skromne foldery „od Grabowskiego”, albo jednostronne wydruki z Ogniska Polskiej YMCA. Czasem również zaproszenia na private view oraz zestawy dokumentów fotograficznych. W wypadku galerii niepolskich poszukiwania są bardziej mozolne i czasem skazane na niepowodzenie. Nazwiska polskie bywają poprzekręcane lub nieobecne w folderach, a dane bio- 
graficzne bałamutne lub niepełne. Niemniej, katalogi i foldery są najlepszym źródłem weryfikacji dat granicznych ekspozycji oraz spisu pokazywanych obiektów. Bezcenne są katalogi wystaw zbiorowych Zrzeszenia Plastyków Polskich lub Stowarzyszenia Fotografików. Pozwalają one zanotować daty roczne, czasem także wraz z nazwami galerii, wystaw poszczególnych artystów, co stanowi podstawę do dalszych poszukiwań;

- opracowania: teki artystyczne, książki biograficzne i historyczne, monografie galerii, muzeów, słowniki itp. Ilościowo, mamy do czynienia z dużą liczbą publikacji, głównie w języku angielskim, w których zanotowane są nazwiska polskich artystów plastyków. Najczęściej dotyczy to tych samych nazwisk: Herman, Epstein, Meninsky, Topolski, a w ostatnich latach także Wiszniewski. W publikacjach dotyczących London Group dochodzą jeszcze: de Karlowska, Gotlib, Potworowski i Frenkiel. Nieco więcej nazwisk zawierają opracowania poświęcone A.I.A. (Association of International Artists). Jednak najczęściej pojawiające się nazwiska nie mają odniesienia do konkretnych wydarzeń artystycznych, a są jedynie potwierdzeniem udziału w wystawach organizacji czy stowarzyszenia, niestety, bez dat. Nieliczne monografie (Frenkiel, Herman, Adler, Ruszkowski, Kossowski) najczęściej identyfikują wystawy z miejscem, czasem z ogólną datą roczną, rzadko z informacją, jakie prace były eksponowane, ile sprzedano i komu;

- źródła drukowane — autobiografie, dzienniki, wspomnienia. Jest ich niewiele i podzielić je można na druki oraz publikacje internetowe. Jedne i drugie są bardzo trudne do zweryfikowania, paradoksalnie najbardziej wówczas, gdy ukazały się za życia artysty. Przykładem może być autobiografia Feliksa Topolskiego, w której wydarzenia i daty zostały podporządkowane atrakcyjnej formie edytorskiej. To samo dotyczy Internetu. Ocena jego wiarygodności jest najtrudniejsza. Strony www poświęcone poszczególnym artystom są daleko niekompletne (Frenkiel, Gotlib, Potworowski) lub nie zawierają żadnych informacji na temat wystaw (Topolski).

Największą wartość mają archiwalia. Zachowało się jednak niewiele, mniej lub bardziej, kompletnych spuścizn archiwalnych po artystach. Wśród najciekawszych należy wymienić zespoły archiwalne znajdujące się w Toruniu, tj.: zbiór dokumentów na temat Grupy 49 (ze zbiorów Ryszarda Demela), archiwum Drian Galleries oraz dokumentację archiwalną: Halimy Nałęcz, Haliny Korn, Marka Żuławskiego, Mariana Kratochwila, Stanisława Frenkla, Aleksandra Wernera, Janusza Eichlera, Mariana Kościałkowskiego, oraz Adama Kossowskiego. Na szczęście, znajdują się w nich również materiały dotyczące znajomych i przyjaciół w sztuce, a katalogi wystaw zbiorowych, spisy obiektów, korespondencje dotyczące wystaw oraz archiwalia drukowane - afisze, zaproszenia, fotografie - dają obraz życia artystycznego całego ,polskiego” Londynu.

Warto na koniec wspomnieć o jeszcze jednym, zupełnie niedocenionym, źródle informacji o wystawach artystów. Mam na myśli naklejki i stemple galerii oraz muzeów (czasem w formie zawieszki), kładzione najczęściej na ramie obrazu, z informacją o wystawie.

\section{Podsumowanie}

W roku 1959 miało miejsce ponad 150 wydarzeń - dotyczących polskiego środowiska artystycznego — w całej Wielkie Brytanii (choć głównie w Londynie), co daje nam średnio jedno wydarzenie artystyczne na dwa dni. Stąd tytuł szkicu: Co dwa dni wernisaż. Wydarzeń bardzo różnych, o trudnej do porównania randze i wartości artystycznej. Jak bowiem zestawić ze sobą w ocenie wystawę Marka Żuławskiego w jednej 
z najlepszych londyńskich galerii — Zwemmer Gallery przy Lichfield Street - z wystawą rysunków i kolaży dzieci z polskich szkół sobotnich w Instytucie im. gen. Sikorskiego? Jak porównać indywidualną ekspozycję fotografii członka największych światowych stowarzyszeń fotografików Władysława Marynowicza z wystawą filatelistyczną lub fotografiami religijnymi? Jednak każde z tych wydarzeń organizowało i gromadziło Polaków gotowych poświęcić czas czy pieniądze, by brać udział w życiu artystycznym.

Nie wiemy prawie nic o liczbie osób odwiedzających wystawy w Londynie. Niektóre, ale bardzo nieliczne, recenzje z wernisaży mówią o gościach w pierwszym dniu otwarcia, nie odnotowując żadnej liczby. Niektóre fotografie z wernisaży pozwalają określić w przybliżeniu jak wiele osób mogło zmieścić się w dwóch, czy trzech pomieszczeniach galerii. Mówi się o kilkudziesięciu osobach, ale to zbyt mało by móc zaryzykować ocenę wartościującą. Tam, gdzie dane były w omówieniu podawane, starano się je przytaczać.

Nie wiemy nic o liczbie osób biorących udział w wycieczkach organizowanych przez Polską YMCA. Wolno jednak przyjąć, biorąc pod uwagę determinację, z jaką Marian Bohusz-Szyszko przygotowywał coraz to nowe odczyty i prelekcje, że osób tych musiało być wiele, a w okresie letnim dochodzili do nich przybysze z Polski. Należy przy tym zwrócić szczególną uwagę na ogromną kulturotwórczą rolę Polskiej YMCA, kierowanej w 1959 roku przez B. T. Lesieckiego. Polska YMCA posiadała po II wojnie światowej sekcje we Francji, Niemczech, Szwajcarii i Wielkiej Brytanii — wszędzie tam, gdzie znajdowały się większe skupiska Polaków ${ }^{17}$. Sekcja brytyjska prowadziła Ogniska w Londynie, w Barnsley i w Sheffield oraz biblioteki we wszystkich ośrodkach i w Edynburgu. YMCA prowadziła akcję kulturalno-oświatową, sportową i rozrywkową, obozy letnie i wycieczki, organizowała wystawy, widowiska i pokazy, wynajmowała kostiumy teatralne i opiekowała się organizacjami artystycznymi. Wydawała także „Poradnik Kulturalno-Oświatowy"18. Londyńskie Ognisko Polskiej YMCA znajdowało się na uboczu (na Bayswater, niedaleko od Paddington), nie było związane z żadnymi organizacjami i ugrupowaniami politycznymi. Było długi czas jedyną instytucją, która interesowała się rozwojem polskiej plastyki na uchodźstwie. YMCA przyjęła pod swoje skrzydła Zrzeszenie Plastyków Polskich w Wielkiej Brytanii, a w sali wystawowej Ogniska odbywały się regularne wystawy i spotkania malarzy, rzeźbiarzy i grafików. Nawet po powstaniu Galerii Grabowskiego, liczne wystawy członków ZPP nadal odbywały się domu przy 46/47 Kensington Gdns Square.

$\mathrm{Z}$ ramienia YMCA odbywały się, co niedzielę, wspomniane wyżej wycieczki artystyczne po galeriach londyńskich i niedalekich muzeach dla Polaków zainteresowanych poznaniem malarstwa. Opiekunem i przewodnikiem tych wycieczek był Marian Bohusz-Szyszko. Z lokalu Ogniska Polskiej YMCA korzystało także Studium Malarstwa Sztalugowego Społeczności Akademickiej USB tegoż Mariana Bohusza-Szyszko. O roli Polskiej YMCA piszą szczegółowo Bogdan Czaykowski i Bolesław Sulik ${ }^{19}$. Z Polską YMCA związane są także sukcesy polskich fotografików, którzy w końcem lat 50. zaczęli odnosić sukcesy w konfrontacji z fotografikami brytyjskimi. Dorobek fotografików polskich w Wielkiej Brytanii, tej miary co Władysław Marynowicz czy Jerzy S. Lewiński, a także wystawy, w których brali udział, to jedna z wielu kart sztuki polskiej w Wielkiej Brytanii. Sukcesy fotografii emigracyjnej odnotowywały czasopi-

${ }^{17}$ B. Czaykowski, B. Sulik, Polacy w W. Brytanii, Paryż 1961, s. 335.

${ }^{18}$ Rocznik Polonii 1958-59, Londyn [1959], s. 211.

${ }^{19}$ B. Czaykowski, B. Sulik, Polacy w W. Brytanii, s. 335-337. 
sma: „Wiadomości” i „Tydzień Polski”, a także „Biuletyn Stowarzyszenia Fotografików Polskich - Polska YMCA", biuletyny YMCA oraz katalogi wystaw. W okresie po 1990 roku dorobek fotografii emigracyjnej pokazywany był w Polsce w związku z międzynarodowymi wystawami „Polska fotografia w świecie”, prezentowanymi na Zamku Książąt Pomorskich w Szczecinie $(1991,1999)^{20}$, a także doczekał się niewielkiego opracowania ${ }^{21}$.

${ }^{20}$ K. Łyczywek, Stowarzyszenie Fotografików Polskich w Londynie, [w:] V Sympozjum Historyczne, Szczecin 14-16 VI 1991, Szczecin 1991.

${ }^{21}$ Taż, Stowarzyszenie Fotografików Polskich w Londynie, [w:] Leksykon kultury polskiej poza krajem od roku 1939, pod red. K. Dybciaka i Z. Kudelskiego, t. 1, Lublin 2000, s. 418-420; por. też: Sztuka polska w Wielkiej Brytanii 1940-2000, s. 417-447. 
Grudzień 1958 - styczeń 1959, Drian Gallery, 7 Porchester Place, Marble Arch, Londyn Wystawa malarstwa Polki z Paryża — Lutki Pink ${ }^{22}$.

Grudzień 1958 - styczeń 1959, Obelisk Gallery, Londyn Wystawa malarstwa Jankiela Adlera. Z recenzji Marka Żuławskiego dla BBC:

\begin{abstract}
Ostatnie obrazy Adlera są obiektami o fantastycznie wypracowanej fakturze, która w połączeniu z ekspresywnością w traktowaniu ludzkiej postaci będącej z reguły tematem jego malarstwa - wytwarza niezwykłe napięcie wewnętrzne. To napięcie właśnie sprawia, że koło obrazów Adlera nie podobna przejść obojętnie. Samotne i hieratycznie zdeformowane postacie na jego obrazach przypominają w pewnym sensie Picassa, podczas gdy przekorna estetyzacja i dekoratywność jego koloru przypomina Paula Klee, chociaż z drugiej strony niezwykły ciężar gatunkowy i klasyczna równowaga cechujące obrazy Adlera są wyłączną jego własnością. Malowane przez niego siedzące postacie i martwe natury złożone $\mathrm{z}$ nierozpoznawalnych przedmiotów mają jakąś solidność i konkretność naturalnego zjawiska. Adler nigdy nie wyciągnął ostatecznych konkluzji ze swoich abstrakcyjnych tendencji. Był za bardzo malarzem, żeby burzyć to, co przez wieki stanowiło treść malarstwa, i dlatego poprzestał na interpretacji natury. Cechą charakterystyczną jego malarstwa jest męski wigor i odwaga koncepcji. Na dnie każdej jego kompozycji czuje się szacunek dla logiki i dla natury ${ }^{23}$.
\end{abstract}

4 stycznia, Polska YMCA, 46/47 Kensington Gdns Square, Londyn Przez cały rok 1959, podobnie jak w latach ubiegłych, Polska YMCA organizowała swego rodzaju ,wycieczki artystyczne” do muzeów, galerii i zabytkowych budynków w Londynie i okolicach. Przewodnikiem tych wycieczek był zawsze prof. Marian Bohusz-Szyszko, który w czasie wycieczki wygłaszał prelekcję na temat oglądanych zbiorów lub wykład o sztuce. Co tydzień (z pewnymi wyjątkami) ukazywało się w „Dzienniku Polskim i Dzienniku Żołnierza”, a później w „Tygodniu Polskim”, wychodzącym w piątek, ogłoszenie o wycieczce w najbliższą niedzielę. Chętni zbierali się w bądź to w lokalu YMCA, bądź już w muzeach. Wycieczka w grupie pozwalała na zakup ulgowych biletów. Pierwsza wycieczka w roku 1959 wyruszyła do Victoria \& Albert Museum $^{24}$.

Początek roku, City Art Gallery, 1 Wentworth Terrace, Wakefield Wystawa „Continental British School of Painting” (Kontynentalno-Brytyjska Szkoła Malarska), później pokazywana w Bradford i Londynie. Na wystawie zaprezentowano prace dziesięciu malarzy brytyjskich, przybyłych z kontynentu, lecz odrębnych wobec sztuki angielskiej. Byli to: Martin Bloch (Ślązak), Jacob Bornfriend, Marek Żuławski, Oskar Kokoschka, Józef Herman, Jankiel Adler, Henryk Gotlib, Fred Uhlman, Zdzisław Ruszkowski i Piotr Potworowski ${ }^{25}$. „The Studio" w obszernej, bardzo pochlebnej recenzji

${ }_{22}^{2}$ M. Wykes-Joyce, Drian Galleries, London 2009, s. 11, 22.

23 Archiwum Emigracji Biblioteki Uniwersyteckiej w Toruniu (dalej AE), Kolekcja M. Żuławskiego (dalej MŻ), M. Żuławski, ,Round the Galleries No 43”, mps, 1-3 k.

${ }^{24}$ Odczyty i wystawy, DPDŻ 3.01.1959, s. 4.

${ }^{25}$ Mark Barrow Fine Art. 20th Century British and International Contemporary Art [on-line]. [Dostęp: październik 2010]. Dostępny w WWW: http://www.markbarrowfineart.com/herman _biog.htm; A. Drwęska, Continental-British, TP 1959 nr 13, s. 13. 
Helen Kapp zamieściło ilustracje obrazów: J. Herman, Village Street in Wales (1949); J. Adler, A Woman with Grapes (1938/1939); H. Gotlib, Pottery on the Window Sill (1956); M. Żuławski Standing nude (1957); Z. Ruszkowski Jennifer in the Garden ${ }^{26}$.

Początek roku, Bradford City Art Gallery, Bradford Wystawa „Continental British School of Painting” (Kontynentalno-Brytyjska Szkoła Malarska), która wcześniej pokazywana była w Wakefield Art Gallery, a później w Londynie. Wśród dziesięciu wystawionych malarzy znaleźli się: Marek Żuławski, Józef Herman, Jankiel Adler, Henryk Gotlib, Zdzisław Ruszkowski i Piotr Potworowski ${ }^{27}$.

Styczeń, „Orzeł Biały-Syrena”, Londyn

Ukazało się ogłoszenie: „Konkurs na plakat Polskiej Galerii Sztuki. Informacje: M. B. Grabowski, Export-Import Ltd., 175 Draycot Avenue, London, S.W. 3 - England”. Była to zapowiedź powstania Grabowski Gallery ${ }^{28}$. W lipcu odbyło się zebrane jury konkursu w składzie: Mateusz Grabowski, Zygmunt Kowalewski, Aleksander Werner i Marek Żuławski. Jury nie przyznało pierwszej nagrody, a jedynie drugą. Otrzymał ją Władysław R. Szomański, który w latach późniejszych projektował dla Galerii różne druki ${ }^{29}$.

Styczeń, Drian Gallery, 7 Porchester Place, Marble Arch, Londyn Doroczna wystawa „Selection of Drian Artists Exhibition”,30, z udziałem polskich artystów: Lutki Pink (z Paryża), Zbigniewa Adamowicza (z Londynu), Halimy Nałęcz (z Londynu), George'a Van Haardta (ps. Jerzego Brodnickiego z Paryża) ${ }^{31}$.

Styczeń, Polish Programmes BBC, Londyn Audycja Marka Żuławskiego poświęcona wystawom Jankiela Adlera, Eduardo Paolozziego i sztuki sowieckiej. ,Round the Galleries” $\mathrm{nr} 43^{32}$.

7 stycznia, Polska YMCA, 46/47 Kensington Gdns Square, Londyn Odczyt Jana Ostrowskiego, redaktora „Dziennika Polskiego i Dziennika Żołnierza” pt. „Polskie życie kulturalne Londynu w 1958 roku”33.

8-31 stycznia, Zwemmer Gallery, Lichfield Street, Londyn Wystawa obrazów Marka Żuławskiego — „Recent Paintings by Marek Żuławski”34.

${ }^{26}$ H. Kapp, The Continental British School of Painting, The Studio 1959 (maj), s. 129-134.

${ }^{27}$ Mark Barrow Fine Art...; A. Drwęska, Continental-British, s. 13.

${ }^{28}$ [Konkurs z nagrodami...], Orzeł Biały-Syrena (dalej: OB-S) $1959 \mathrm{nr} 3$, s. 4.

${ }^{29}$ AE, Kolekcja Władysława R. Szomańskiego, Korespondencja, List M. B. Grabowskiego do W. R. Szomańskiego z 21 lipca 1959; Wyniki konkursu na plakat Galerii Grabowskiego, DPDŻ 24.07.1959, s. 2; M. B. Grabowski, Wyniki konkursu na plakat Galerii Grabowskiego, Wiadomości (dalej: W) 1959 nr 32(697), s. 5.

${ }^{30}$ Selection of Drian Artists, 4-24th January, 1971, daily 10-6, Saturdays 10-1 [folder wystawy] Drian Galleries, London 1971.

${ }^{31}$ Kronika, Wystawa w Drian Gallery, W 1959 nr 9(674), s. 6.

${ }^{32}$ AE, MŻ, M. Żuławski, ,,Round the Galleries No 43”, mps, 5 k.

${ }^{33}$ Odczyty i wystawy, DPDŻ 3.01.1959, s. 4.

${ }^{34}$ Catalogue of Recent Paintings by Marek Zulawski [katalog wystawy], Zwemmer Gallery, London 1959; Kronika, Wystawa Żuławskiego, W 1959 nr 6(671), s. 6; G. S. Whittet, London commentary, The Studio 1959 (kwiecień), s. 125. 
Kolor bardzo szlachetny, spokojny i niski w tonacji wytwarza raczej nastrój melancholii. Biele są dziwnie chłodne - prawie martwe - czernie matowe i smutne. Zreszta świat, który Żuławski odmalowuje nie jest zbyt wesoły, lecz w jego interpretacji blade te kobiety i mężczyźni proletariatu są przygnieceni ciężarem życia i zupełnie pozbawieni jakiegokolwiek wigoru. Bardziej żywe „ludzkie” są jego martwe natury i dla mnie najpiękniejszym obrazem jest kompozycja z czerwonym dzbankiem do kawy. Jaskrawo-szkarłatna, dramatyczna płachta koloru jest prawie krzykiem radości. Zmysłowość czerwieni została jeszcze podkreślona grubą, zawiesistą warstwą pięknie położonej farby. Konstrukcja kompozycji jest jasna, prosta i świetnie zbalansowana. Prostota tej martwej natury jest bardziej elokwentna niż niektóre kompozycje figuralne, raczej ilustracyjne niż malarskie. Marek Żuławski stara się połączyć ekspresjonistyczny realizm z klasycznym konstruktywizmem kubizmu. Z natury — wydaje mi się jest bliższy klasycyzmu i tam gdzie operuje czystą formą, kolorem i farbą (ma b. piękną fakturę) i nie ulega zbytnio wymaganiom tematyki, tam osiąga najlepsze rezultaty ${ }^{35}$.

11 stycznia, Polska YMCA, 46/47 Kensington Gdns Square, Londyn Wycieczka artystyczna Polskiej YMCA do British Museum z prelekcją Mariana Bohusza-Szyszko pt. „Kultury indyjskie”, ${ }^{36}$.

18 stycznia - 13 lutego, Polska YMCA, 46/47 Kensington Gdns Square, Londyn Indywidualna Wystawa Fotografii Artystycznej Władysława Marynowicza. Artysta pokazał 120 prac (portrety, martwa natura, abstrakty) ${ }^{37}$. Otwarcia dokonał Feliks (Ref-Ren) Konarski ${ }^{38}$.

Anglicy cenią Marynowicza, darzą go nie tylko członkostwem swych instytucji czy nagradzają na wystawach, ale też ma on posadę w jednej ze szkół londyńskich, gdzie wykłada fotografikę ${ }^{39}$.

W notatce w ,Dzienniku Polskim” napisano, że fotografia Marynowicza ma świetlistość, bogactwo tonu i plastykę, które prawie wykraczają poza normalne możliwości fotografii ${ }^{40}$.

18 stycznia, Polska YMCA, 46/47 Kensington Gdns Square, Londyn Wycieczka artystyczna Polskiej YMCA do Tate Gallery z prelekcją Mariana Bohusza-Szyszko ${ }^{41}$.

18-25 stycznia, Klub Polski, Dom Inwalidów Wojskowych PSZ, 18-20 Soho Rd., Birmingham

Wystawa prac inwalidów wojennych polskich i brytyjskich ${ }^{42}$.

20 stycznia - 7 lutego, University of Leeds, Leeds Wystawa „The Mission to The University” z udziałem Marka Żuławskiego ${ }^{43}$.

\footnotetext{
35 A. Drwęska, Wystawa obrazów Marka Żuławskiego, DPDŻ 24.01.1959, s. 3.

${ }^{36}$ Odczyty i wystawy, DPDŻ 10.01.1959, s. 4.

${ }^{37}$ Biuletyn. Stowarzyszenie Fotografików Polskich — Polska YMCA, Londyn [1959] nr 1, s. 26.

${ }^{38}$ Odczyty i wystawy, DPDŻ 16.01.1959, s. 4; Wystawa fotografii, DPDŻ 23.01.1959, s. 3.

${ }^{39}$ S. Legeżyński, Fotografika Wt. Marynowicza, Gazeta Niedzielna 1959 nr 6(508), s. 9.

${ }^{40}$ Wystawa fotografii, DPDŻ 16.02.1959, s. 3.

${ }^{41}$ Odczyty i wystawy, DPDŻ 17.01.1959, s. 4.

${ }^{42}$ Tamże; Wystawa inwalidów w Birmingham, DPDŻ 22.01.1959, s. 3.

43 AE, MŻ, Wystawy 1951-1959, ,«Mission to the University». Exhibition”, 1 k. mps.
} 
21 stycznia, Dom Polski im. gen. Sikorskiego, 7 Clarmont Gdns, Glasgow Wystawa fotografii - 80 zdjęć z groty w Carfin. Otwarcia dokonał ks. Jan Gruszka; następnie dr W. Grossman wygłosił odczyt o stratach kościoła Katolickiego w czasie II wojny światowej. Wystawa miała być pokazywana także w innych polskich ośrodkach i parafiach w Szkocji ${ }^{44}$.

25 stycznia, Polska YMCA, 46/47 Kensington Gdns Square, Londyn Odczyt Mariana Bohusza-Szyszko w Ognisku Polskiej YMCA pt. „Okres Matejkowski”45.

27 stycznia - 9 lutego, Drian Gallery, 7 Porchester Place, Marble Arch, Londyn Wystawa obrazów René Laubièsa ${ }^{46}$.

Styczeń/luty, R.W.S. Galleries, Londyn

$\mathrm{Na}$ wystawie zorganizowanej przez Society of Portrait Sculptors znalazła się rzeźba Jacoba Epsteina Maria Donska, której zdjęcie znalazło się w „The Studio”47.

Styczeń/luty, Hammersmith College of Building and Arts, Londyn Powstało Koło Polskie na Hammersmith College of Building and Arts, pod przewodnictwem J. Stawana. Koło urządziło małą wystawę polskiej sztuki ludowej, na której pokazano wyroby podhalańskie, lalki łowickie, wycinanki itp. Wystawa była jedną z serii wystaw urządzanych przez różne koła College $e^{48}$.

Luty, ,The Studio”, Londyn

W miesięczniku „The Studio”, w cyklu artykułów na temat współczesnej młodej sztuki światowej, ukazał się szkic Aleksandra Wojciechowskiego pt. Polish Art: the Younger Figurative Painters, w którym zamieszczono ilustracje obrazów J. Nowosielskiego, T. Brzozowskiego, W. Cwenarskiego, K. Mikulskiego, J. Lebensteina, J. Tchórzewskiego, R. Ziemskiego, A. Wróblewskiego i G. Obremby ${ }^{49}$.

1 lutego, Polska YMCA, 46/47 Kensington Gdns Square, Londyn Wycieczka artystyczna Polskiej YMCA do Royal Academy of Arts z prelekcją Mariana Bohusza-Szyszko ${ }^{50}$.

4 lutego - początek marca, Grabowski Gallery, 84 Sloane Avenue, Chelsea, Londyn Otwarcie Galerii Grabowskiego (Grabowski Gallery) przy 84 Sloane Avenue w Chelsea (London S.W.3.) ${ }^{51}$.

${ }^{44}$ Grota $w$ Carfin w fotografii, DPDŻ 21.01.1959, s. 3.

45 Odczyty i wystawy, DPDŻ 24.01.1959, s. 4.

${ }^{46}$ AE, Kolekcja Halimy Nałęcz (dajej HN), Drian, Rene Laubies [zaproszenie na wystawę]; René Laubiès. Water Colors and Inks from Haïti and Alabama [folder wystawy], [London 1959].

${ }^{47}$ G. S. Whittet, London commentary, The Studio 1959 (luty), s. 61.

${ }^{48}$ Polacy na Hammersmith, DPDŻ 24.02.1959, s. 3. s. $33-41$.

${ }^{49}$ A. Wojciechowski, Polish Art: The Younger Figurative Painters, The Studio 1959 (luty),

${ }^{50}$ Odczyty i wystawy, TP $1959 \mathrm{nr} 1, \mathrm{~s} .12$.

${ }^{51}$ Polska Galeria Sztuki, DPDŻ 3.02.1959, s. 3; A. Drwęska, „Grabowski Gallery”, DPDŻ 11.02.1959, s. 3. 
Sama galeria jest piękna w swej prostocie i dekoracji: ma białe ściany nakryte ciemnoszafirowym sufitem, który podtrzymują drewniane belki zaprawione na kolor jasnożółty ${ }^{52}$.

Opiekę artystyczną nad galerią objęło Zrzeszenie Plastyków Polskich w Wielkiej Brytanii, stąd wystawą inaugurującą jej otwarcie była zbiorowa ekspozycja członków $\mathrm{ZPP}^{53}$. Z rozmowy z prezesem ZPP:

Dotychczas mgr Grabowski zajmował się farmaceutyką i wysyłką paczek do Polski obecnie (widocznie mało ma kłopotów) otworzył w samym sercu artystycznej Chelsea prześliczną galerię, gdzie zamierza wystawiać prace polskich plastyków z obydwóch stron żelaznej kurtyny, oraz wyroby polskiej sztuki ludowej, a także obrazy i rzeźby artystów innej nacji. [...] Łączniczką między Związkiem a właścicielem galerii jest p. Sukiennicka, sekretarka Zrzeszenia i jednocześnie pracowniczka w firmie p. Grabowskiego. Otwarcie galerii zainaugurowała wystawa prac kilku członków Zrzeszenia Polskich Plastyków, obejmująca ponad 40 prac — olejów, rzeźb i rysunków, obok kilimów i eksponatów sztuki ludowej z Polski. [...] Wystawiają tym razem przeważnie byli uczniowie prof. Bohusza-Szyszki z mistrzem na czele, który pokazał trzy obrazy z cyklu Chrystusowego ${ }^{54}$.

Pokazano prace następujących artystów: Janina Baranowska, Andrzej Bobrowski, Marian Bohusz-Szyszko, Mieczysław Chojko, Antoni Dobrowolski, Stanisław Frenkiel, Marian Kościałkowski, Maryla Michałowska, Piotr Mleczko, Józef Piwowar, Halina Sukiennicka, Zygmunt Turkiewicz, Tadeusz Znicz-Muszyński ${ }^{55}$. Galeria działała do roku 1975 i była otwarta codziennie w godzinach $10.00-18.00$, za wyjątkiem niedziel i świąt. Wystawa była następnie pokazywana w Monachium (10-30 kwietnia) i Hamburgu (10-31 maja $)^{56}$. Otwarcie galerii odnotowała cała polska prasa w Londynie, także „Oblicze Tygodnia”, ukazujące się ,pod opieką” Ambasady PRL ${ }^{57}$. Napisano tam:

Cechą charakterystyczną omawianej wystawy, która uderza nawet niefachowego widza, jest nowoczesność wszystkich wystawionych prac. Nie ma na wystawie ani jednego obrazu wykonanego wedle starych tradycyjnych wzorów. Zwraca to uwagę tym bardziej, że wielu autorów rozpoczynało swą karierę twórczą przed wojną ${ }^{58}$.

Lecz już tydzień później:

Żadne $\mathrm{z}$ wystawionych płócien nie stanowiło rewelacji, ale ogólny poziom był przyzwoicie wyrównany, co jak na początek wystarcza. Do najciekawszych indywidualności zaliczyłbym A. Dobrowolskiego, Z. Turkiewicza i T. Znicz-Muszyńskiego ${ }^{59}$.

Recenzenci zwrócili uwagę na nowe w sztuce Turkiewicza abstrakcje ${ }^{60}$.

${ }^{52}$ Raptularz. W Londynie - nienajgorszym polskim mieśsie, Horyzonty 1959 nr 35, s. 70.

53 A. Drwęska, „Grabowski Gallery”, DPDŻ 11.02.1959, s. 3; Polska Galeria Sztuki w Londynie. Nowa inicjatywa mgr. Grabowskiego, Gazeta Niedzielna 1959 nr 5(506), s. 9.

${ }^{54}$ Polska Galeria Sztuki w Londynie..., s. 9.

${ }^{55}$ Otwarcie Galerii Sztuki Grabowskiego, Gazeta Niedzielna 1959 nr 7(509), s. 9.

${ }^{56}$ J. Baranowska, Rozmowa z... Sekretarzem Zrzeszenia Plastyków Polskich w W. Brytanii, rozm. MERK, Merkuriusz Polski - Życie Akademickie — Młoda Sztuka, 1960 nr 10-11(125126), s. 11.

${ }^{57}$ Polska galeria obrazów w Londynie, Oblicze Tygodnia (dalej: OT) 1959 nr 17(77), s. 11; Gazeta Niedzielna $1959 \mathrm{nr}$ 8(509), s. 8 - tam fotografia pomieszczeń.

${ }^{58}$ Ker., Plastycy polscy w Galerii Grabowskiego, OT $1959 \mathrm{nr} 22(82)$, s. 6.

${ }^{59}$ S. H., Jeszcze o Galerii Grabowskiego, OT $1959 \mathrm{nr} 23(83)$, s. 11.

${ }^{60}$ Notatki, Gazeta Niedzielna 1959 nr 9(510), s. 9. 
8 lutego, Polska YMCA, 46/47 Kensington Gdns Square, Londyn Odczyt Mariana Bohusza-Szyszko o malarstwie angielskim w Wallace Collection ${ }^{61}$.

11 lutego, Polska YMCA, 46/47 Kensington Gdns Square, Londyn Odczyt B. Sochy Brzostowskiego „Wielkie Kaszuby — powojenne oblicze, kultura, historia, etnografia”, któremu towarzyszyła wystawa zdjęć i publikacji ${ }^{62}$.

11-28 lutego, Drian Gallery, 7 Porchester Place, Marble Arch, Londyn Wystawa malarstwa Gwena Barnarda. W galerii pokazano 21 prac $^{63}$.

Do 13 lutego, Royal Society of British Artists Galleries, 66 Suffolk St., Londyn Indywidualna wystawa 20 rzeźb Aliny Ślesińskiej w R.B.A. Galleries ${ }^{64}$. Rzeźbiarka dwa lata wcześniej wyjechała z Polski. Miała wystawę we Francji; otrzymała też Nagrodę Artystyczną „,Kultury” za rok 1957. Po wernisażu wystawy w Londynie napisała do Konstantego Puzyny:

Sukces mojej wystawy w Londynie jest $2 \times$ większy niż w Paryżu. To chyba ci wystarczy. PAP 12 II będzie referować w całej prasie krajowej. Nie będzie chyba pisma w Anglii, które by z entuzjazmem nie pisało o mojej wystawie [...] dzisiaj w jednym z pism była zamieszczona moja fotografia i między wierszami napisane... Miss Slesinska was at the exhibition today in a stylish white coat. She is an attractive redhead ${ }^{65}$.

Wystawa była pierwszą po 1945 roku prezentacją polskiej sztuki w Wielkiej Brytanii. Z recenzji Alicji Drwęskiej:

Ani śladu w jej rzeźbach socjal-realizmu — nawet w najstarszych jej pracach sprzed 5 lat, portretach Marii Dąbrowskiej i Dunikowskiego, raczej impresjonistyczne niż naturalistyczne [...] Rzeźby jej są właściwie zupełnie abstrakcyjne — łączy je z obiektem zaledwie daleka aluzja, lecz forma ich jest pełna ekspresji i bardzo ewokacyjna ${ }^{66}$.

Wystawę odnotowało „Oblicze Tygodnia” — czasopismo wydawane „pod opieką” Ambasady PRL:

Większość rzeźb to dzieła ciążące ku abstrakcji. Ale metoda abstrakcyjna — i tu leży chyba jedno ze źródeł sukcesów Ślesińskiej - nie ma nic wspólnego z kuglarstwem formalnym. Abstrakcja to dla tej artystki uogólnienie, nigdy jednak takie w którym zostaje całkowicie zerwany związek z przedmiotem [...]. Krytyka angielska oceniła wystawę Aliny Ślesińskiej z dużą sympatią ${ }^{67}$.

Wystawę odnotowała również „Gazeta Niedzielna”68.

15 lutego, Polska YMCA, 46/47 Kensington Gdns Square, Londyn

${ }^{61}$ Odczyty i wystawy, TP $1959 \mathrm{nr} 2$, s. 12.

${ }^{62}$ Odczyty i wystawy, DPDŻ 11.02.1959, s. 4.

${ }^{63}$ J. W. Sienkiewicz, Polskie galerie sztuki w Londynie..., s. 273.

${ }^{64}$ Kronika, Dwie wystawy, W 1959 nr 7(672), s. 6.

${ }^{65}$ P. Reiter, 8 gipsów. Alina Ślesińska, Wysokie Obcasy 2007 nr 49(450), s. 18.

${ }^{66}$ A. Drwęska, Rzeźby Aliny Ślesińskiej, DPDŻ 17.02.1959, s. 3 - tam fotografia: A. Ślesińska obok swojej rzeźby Cyrk.

${ }^{67}$ G. S. Whittet, London commentary, The Studio 1959 (maj), s. 158 - tam zdjęcie rzeźby A. Ślesińskiej Xawery Dunikowski; (S), Alina Ślesińska, OT 1959 nr 21(81), s. 6.

${ }^{68}$ Notatki, Gazeta Niedzielna 1959 nr 9(510), s. 9. 
Wycieczka artystyczna Polskiej YMCA do British Museum, z odczytem Mariana Bohusza-Szyszko pt. „Drzeworyty japońskie”,69.

Połowa lutego, Instytut Historyczny im gen. Sikorskiego, 20 Princes Gate, Londyn Pierwsze w historii Instytutu „lekcje historii w Instytucie”, tj. zwiedzanie placówki przez dzieci polskie ze szkół sobotnich. Wycieczkę w lutym zorganizowała Szkoła Przedmiotów Ojczystych im. A. Mickiewicza z Brockley Lewisham. Oprowadzał po Instytucie płk Jerzy Krupski ${ }^{70}$.

Do 21 lutego, Woodstock Gallery, 16 Woodstock St., Londyn Pierwsza indywidualna wystawa malarstwa Andrzeja Kuhna ${ }^{71}$.

Czerwienie o ceglastym odblasku, ciepłe żółcie, ostre ultramaryny, różowawe fiolety i zimne zielenie łączą się w kompozycjach Kuhna w pięknie stonowane i pełne rytmu harmonie. Przedmioty, pejzaż i postacie ludzkie - lekko groteskowe - określone konturem czystym i zdecydowanym mimo płaskości posiadają przestrzenność i mimo pewnej schematyczności formy — dużo ekspresji. Dekoracyjność kompozycji Kuhna łączy się z poetyckością wizji i czasami przypominają mi jego obrazy wczesne malarstwo Chagalla, trochę sztukę ludową, a także przez żarliwość kolorytu i płaskość — miniatury hinduskie. Lecz mimo tych wszystkich skojarzeń prace Kuhna są świeże, dynamiczne i oryginalne ${ }^{72}$.

20-22 lutego, Polska YMCA, 46/47 Kensington Gdns Square, Londyn Wystawa Filatelistyczna i targi znaczków polskich ${ }^{73}$. Tematem wystawy były polskie poczty działające poza Polską w latach 1939-1945: poczty oficjalne, poczty polowe, poczty obozowe, poczty międzyobozowe i konspiracyjne ${ }^{74}$. Wystawa została zorganizowana z inicjatywy B. T. Lesieckiego, kierownika Polskiej YMCA, we współpracy $\mathrm{z}$ dwiema organizacjami filatelistycznymi w Wielkiej Brytanii: Polskim Towarzystwem Filatelistycznym i Związkiem Filatelistów Polskich w Wielkiej Brytaniii ${ }^{75}$.

21 lutego, ,Tydzień Polski”, Londyn

„Tydzień Polski” wydrukował wywiad z Adamem Kossowskim z okazji zakończenia prac nad monumentalną Droga Krzyżowa w katedrze w Cardiff, w Walii, oraz pochlebnych artykułów na ten temat w londyńskich „Wiadomościach” i „Catholic Herald”.

Między pierwszymi robotami aylesfordzkimi a teraz skończonymi Stacjami upłynęło już — wierzyć się nie chce! — siedem lat. Wypełniły je głównie prace ceramiczne, co raz większe rozmiarem i co raz bardziej skomplikowane technicznie. Więc: trzy wielkie płaskorzeźby na sklepie w Yorku, stacje Męki Pańskiej w Pontypoolu w Walii, czarnobiała supraporta z kafli na Domu Górników w Abertillery w Walii, dekoracja z wielkich kafli (w sumie około 500) w szkole dla dzieci w Cardiff, no i wreszcie tryptyk ołtarzowy w opactwie benedyktyńskim w Downside Abbey. [...]

- Jak doszto do tego zamówienia?

- Katedra katolicka pod wezwaniem walijskiego świętego Dawida w Cardiff, zbudowana w zeszłym stuleciu przez znanego pseudo-gotyckiego architekta Pugina, spłonęła w blitzu w roku 1940. Zostały z niej tylko ściany. Do odbudowy zabrano się na dobre

\footnotetext{
${ }^{69}$ Odczyty i wystawy, TP 1959 nr 3, s. 12.

${ }^{70}$ W. S., Pod sztandarami ojców. Dzieci w Instytucie gen. Sikorskiego, DPDŻ 17.02.1959, s. 3.

${ }^{71}$ Kronika, Dwie wystawy, W $1959 \mathrm{nr}$ 7(672), s. 6.

${ }^{72}$ A. Drwęska, Obrazy Andrzeja Kuhna w West Endzie, DPDŻ 12.02.1959, s. 3.

${ }^{73}$ Odczyty i wystawy, DPDŻ 6.02.1959, s. 4.

${ }^{74}$ Wystawa filatelistyczna, TP $1959 \mathrm{nr}$ 6, s. 7.

75 (Az), Wystawa znaczków w Polskiej YMCA, DPDŻ 16.04.1959, s. 3.
} 
dosyć późno, bo dopiero po 15 latach. Architekt odpowiedzialny za całość, Tom Price, z którym już dawniej miałem sporo do czynienia, powierzył mi robotę Stacji. Razem postanowiliśmy, że mają to być spore rozmiarami wypukłorzeźby ceramiczne i że powinny one grać rolę głównego elementu dekoracyjnego w kościele. Po przezwyciężeniu pewnych oporów i obaw przed nowoczesnymi ekstrawagancjami, mniej więcej półtora roku temu, po przedstawieniu szkiców, kartonów i próbnej Stacji — kapituła zaakceptowała moją osobę, jako wykonawcy.

- Jaka byta następna praca Pana?

- Tympanon sporych rozmiarów dla nowego kościoła w Kent. Został on umieszczony nad głównym wejściem do kościoła i przedstawia zamordowanie świętego Tomasza Becketa, biskupa Canterbury, które jest prawie dokładnym powtórzeniem w Anglii naszej historii świętego Stanisława Szczepanowskiego — tylko sto lat później.

Rozmowa została zilustrowana fotografiami dwóch Stacji ${ }^{76}$.

22 lutego, Polska YMCA, 46/47 Kensington Gdns Square, Londyn Polska YMCA zorganizowała dyskusję na temat grafiki znaczka pocztowego prowadzoną przez Mariana Bohusza-Szyszko. Dyskusja nawiązywała do wystawy filatelistycznej w $\mathrm{YMCA}^{77}$.

Luty/marzec[? ] Waddington Galleries, Londyn Wystawa obrazów Henryka Haydena z Francji ${ }^{78}$.

Marzec, Central Association of Photographic Societies, Londyn

25. doroczna Wystawa Fotografiki z udziałem Stowarzyszenia Fotografików Polskich — Polska YMCA ${ }^{79}$. Stowarzyszenie zdobywa trzecie miejsce w konkursie 40 klubów z Wielkiej Brytanii ${ }^{80}$.

Marzec, Galeria CBWA (Odwach), Poznań

Wystawa indywidualna rysunków Mariana Kościałkowskiego. Rysunki były rok wcześniej pokazywane w Szczecinie w galerii CBWA ${ }^{81}$.

3-21 marca, Drian Gallery, 7 Porchester Place, Marble Arch, Londyn Wystawa malarstwa i rysunków Suzanne Rodillon z Francji ${ }^{82}$.

4-21 marca, Walkers Gallery, 118 Bond St., Londyn Wernisaż wystawy obrazów Teresy Heydel, mieszkającej na stałe na Majorce ${ }^{83}$. Z recenzji Alicji Drwęskiej:

${ }^{76}$ A. Kossowski, Polak ozdobit katedre w Cardiff. „,Droga Krzyżowa” A. Kossowskiego, TP 1959 nr 4, s. 6 - tam dwie ilustracje: stacje Drogi Krzyżowej.

${ }^{77}$ Odczyty i wystawy, TP $1959 \mathrm{nr}$ 4, s. 12.

${ }^{78}$ (n), Polskie życie kulturalne. Warsztaty malarskie i literackie, OB $1959 \mathrm{nr} 16$, s. 5; G. S. Whittet, London commentary, The Studio 1959 (maj), s. 158.

${ }^{79}$ Biuletyn. Stowarzyszenie Fotografików Polskich — Polska YMCA, Londyn [1959] nr 1, s. 26.

${ }^{80}$ M.A.R., Lata 1958-1959..., Biuletyn. Stowarzyszenie Fotografików Polskich — Polska YMCA, Londyn [1959] nr 1, s. 24.

${ }^{81}$ AE, Kolekcja M. Kościałkowskiego, M. A. Supruniuk, „Kalendarium wystaw M. Kościałkowskiego", mps.

${ }^{82}$ AE, HN, Drian, Rodillon. Paintings and Drawings by Suzanne Rodillon [folder wystawy],

[London 1959]; M. Wykes-Joyce, Drian Galleries, s. 23.

${ }^{83}$ Odczyty i wystawy, DPDŻ 2.03.1959, s. 4. 
Kolor - najmocniejszy atut młodej malarki — posiada świeżość, lekkość i świetlistość. Lecz wypełnia on formę raczej nieciekawą i sam, właściwie nie buduje obrazu. Farba, najczystszy kolor z tuby, położona jest krótkimi, lekkimi pociągnięciami pędzla a la Van Gogh [...]. Są to poprawne rysunki ładnych pejzażów, ładnych kwiatów, ładnych wazonów itp. pomalowane techniką pointylistyczną, odtwarzającą dość wyraźnie drgania światła, słoneczność i przestrzenność ${ }^{84}$.

\section{Z recenzji Zygmunta Turkiewicza:}

Dla tej artystki nowe problemy malarskie już nie istnieją. Ona nauczyła się kiedyś malować d o b r z e no i produkuje dzisiaj obrazy o pewnym poziomie przedwojennej Polski [...]. Zasklepiona w swoim p i ę k n y m ś w i e c i e — maluje ładnie [...]. Używanie jednak dzisiaj tych dawno już wyjałowionych i wyeksploatowanych problemów nie wyraża naszej epoki ${ }^{85}$.

\section{$Z$ recenzji S. Zahorskiej:}

Ciepłe jasne i żywe kolory, harmonijny, pointylistyczny ich układ i staranny miękki rysunek nie ujawniły indywidualności artystki. Widocznie potrzebne jest dziś ,wartościowanie" przedmiotu, pejzażu czy portretu - a wartościowanie objawia się w przeinaczeniu, w odejściu od konwencjonalnie przyjętej formy, w nadaniu jej nowego znaczenia i nowej ekspresji ${ }^{86}$.

„Wiadomości” zamieściły reprodukcje dwóch prac malarki: Potijo i Pejzaż z San Matet ${ }^{87}$.

4-14 marca, The Related Art Centre, Park Lane House, 45 Park Lane, Londyn Wernisaż wystawy 23 obrazów olejnych Mieczysława Chojko ${ }^{88}$. Z recenzji Alicji Drwęskiej:

Tytuły obrazów Chojki sugerują i opisują literacką treść ich zawartości. Te na wpół abstrakcyjne, lekko surrealistyczne kompozycje, dla mnie mają wartości plastyczne absolutnie niezwiązane z ich nazwami i nasuwają zupełnie inne skojarzenia, niż te, które autor chciałby narzucić. Błąd. Obraz powinien przemawiać za siebie sam — nie potrzebuje komentarza. Forma i barwa oraz ich wzajemny stosunek do siebie stanowią naturalną funkcję, mowę i treść obrazu. [...] W malarstwie Chojki treść plastyczna wyraża przynajmniej dla mnie - zupełnie coś innego niż bombastyczno-mistyczne tytuły i przypowieści podtytułów. [...] Wystawa malarska Chojki obejmuje prace z okresu 12 lat - prace nie pozbawione walorów plastycznych lecz różne w swej koncepcji i na różnych poziomach ${ }^{89}$.

\section{Z recenzji Zygmunta Turkiewicza:}

Trudno tu mówić o jakiejś jednolitości stylu czy podejściu do zagadnienia, a nawet technika malowania jest jeszcze w stanie eksperymentalnym ${ }^{90}$.

\section{Z recenzji w „Orle Białym”:}

${ }^{84}$ A. Drwęska, Malarka z Balearów, DPDŻ 3.04.1959, s. 3.

${ }^{85}$ Z. Turkiewicz, Wystawa obrazów Mieczystawa Chojki i Teresy Heydel, Gazeta Niedzielna $1959 \mathrm{nr}$ 13(514), s. 11 [podkr. - Z. T.].

${ }^{86}$ S. Zahorska, Rozdroża malarstwa, W $1959 \mathrm{nr} 21(686)$, s. 6.

${ }^{87}$ Kronika, Wystawa Teresy Heydel, W 1959 nr 11(676), s. 6.

${ }^{88}$ Odczyty i wystawy, DPDŻ 6.03.1959, s. 4; Notatki, Gazeta Niedzielna 1959 nr 11(511), s. 9; Kronika, Metek Chojko, W 1959 nr 11(676), s. 6.

${ }^{89}$ A. Drwęska, Wystawa obrazów M. Chojki, DPDŻ 30.03.1959, s. 3.

${ }^{90}$ Z. Turkiewicz, Wystawa obrazów Mieczystawa Chojki i Teresy Heydel, Gazeta Niedzielna $1959 \mathrm{nr}$ 13(514), s. 11. 
Mieczysław Chojko, którego kilka bardzo oryginalnych płócien oglądać można było na wystawie w Galerii Grabowskiego, urządził osobną wystawę na Mayfairze. Mocną stroną jego malarstwa jest doskonałe zharmonizowanie barw na obrazie w tonach bardzo subtelnych przy dużym zrównoważeniu plastycznym całej kompozycji ${ }^{91}$.

Po wystawie M. Chojko, w prywatnym ogłoszeniu zamieszczonym w prasie, zachęcał do oglądania swoich obrazów w domu po wcześniejszym zgłoszeniu listownym ${ }^{92}$.

8 marca, Polska YMCA, 46/47 Kensington Gdns Square, Londyn Wycieczka artystyczna Polskiej YMCA do Victoria \& Albert Museum, z odczytem Mariana Bohusza-Szyszko o sztuce norweskiej ${ }^{93}$.

11 marca - 4 kwietnia, Grabowski Gallery, 84 Sloane Ave., Chelsea, Londyn Druga wystawa w Galerii pn. Contemporary Drawings. Pokazano rysunki (i grafikę) malarzy: Tadeusza Beutlicha, Mariana Bohusza-Szyszko, Mieczysława Chojko, Antoniego Dobrowolskiego, Leona Piesowockiego, Mariana Kościałkowskiego, Haliny Sukiennickiej, Zygmunta Turkiewicza, Tadeusza Znicz-Muszyńskiego ${ }^{94}$. M.in. prace: Antoni Dobrowolski, Holliday Maners; Tadeusz Znicz-Muszyński, Cisza; Leon Piesowocki, Parlament; Marian Szyszko-Bohusz, Odaliska; Marian Kościałkowski, Kompozycja; Tadeusz Beutlich, Dziewczyna z ptakiem; Zygmunt Turkiewicz, Niebieski akt reprodukowane w prasie w Londynie ${ }^{95}$. Z recenzji Alicji Drwęskiej:

Wystawa rysunków w Galerii Grabowskiego jest jakby uzupełnieniem poprzedniej $\mathrm{z}$ dodatkiem prac Beutlicha i Leona (Piesowockiego). Poziom ogólny jest dobry i prawie wszystkie prace są interesujące. Marian (Kościałkowski) pokazał piękne, pełne polotu kompozycje figuratywne i abstrakcyjne [...] Mniej interesujące są gwasze Turkiewicza, ładne w kolorze, lecz forma jest dość mechaniczna: brak jej głębszej ekspresji [...]. Abstrakcyjne lub semiabstrakcyjne kompozycje Beutlicha, mimo, że ograniczają się do czerni, bieli i szarości, są bardzo malarskie i chociaż różnią się bardzo w charakterze od jego prac dawniejszych, jednak pozostała w nich ta sama niepokojąca i trochę niesamowita atmosfera ${ }^{96}$.

\section{Z recenzji w „Gazecie Niedzielnej”:}

Obrazy kwalifikuje jury wyłonione przez Zrzeszenie Plastyków, a więc utrzymany jest właściwy poziom, warunek długotrwałego powodzenia Galerii [...]. Obecna wystawa jest malarsko świetnie wyważona, urządzona bez zarzutu ${ }^{97}$.

Wystawę odnotowało „Oblicze Tygodnia” w ilustrowanym dodatku do nr 27 — tam ilustracje: A. Dobrowolski, Holiday Manera; Marian Kościałkowski, Kompozycja; M. Bohusz-Szyszko, Odaliska; T. Beutlich, Dziewczyna z ptakiem; Z. Turkiewicz, Niebieski akt; T. Znicz-Muszyński, Cisza; L. Piesowocki, Parlament. Z recenzji S. Zahorskiej w „Wiadomościach”:

${ }^{91}$ (n), Polskie życie kulturalne. Warsztaty malarskie i literackie, OB $1959 \mathrm{nr} 16$, s. 5.

${ }^{92}$ Odczyty i wystawy, DPDŻ 10.04.1959, s. 4.

93 Odczyty i wystawy, TP 1959 nr 6, s. 15.

${ }^{94}$ Notatki, Gazeta Niedzielna 1959 nr 11(511), s. 9; J. W. Sienkiewicz, Marian Bohusz-Szyszko, s. 132.

${ }^{95}$ Druga wystawa w Galerii Grabowskiego, OT. Dodatek Ilustrowany 1959 nr 27, s. b-c.

${ }^{96}$ A. Drwęska, Czarno-biate gamy, DPDŻ 25.03.1959, s. 3.

${ }^{97}$ S. Legeżyński, Druga wystawa w nowej galerii. Malarstwo wspótczesne w Galerii Grabowskiego, Gazeta Niedzielna 1959 nr 13(514), s. 15. 
Wystawa grafiki polskiej była na ogół na dobrym poziomie i interesująca. Nie było w niej owej modernistycznej rutyny, która ujawniła się w pomysłach coraz dziwaczniejszych i pozbawionych jakiejkolwiek treści. Abstrakcyjnemu modernizmowi złożyli polscy artyści hołd należyty, nie odżegnali się od niego, ale tu i ówdzie ukazywały się wrota, wiodące poza udeptane ścieżki abstrakcji. Niektórzy, jak np. Beutlich, właśnie co tylko nawrócili się na abstrakcję; na dawniejszych swoich wystawach Beutlich był raczej ekspresyjno-postaciowy, i nie wiem czy wyszło mu na zdrowie że teraz grafika jego jest siecią linii, jakby gęstą tkanką, bez jakiegokolwiek symbolu bliższego człowiekowi. [...] Są jednak i artyści, których modernizm nie wyraża się w abstrakcyjnych kompozycjach. Na tej stosunkowo niewielkiej wystawie reprezentowane były niemal wszystkie główne prądy myślowe i twórcze emigracji. Bohusza-Szyszkę, z jego śmiałymi rysunkami, z grubymi liniami z gwaszu czy atramentu, rzucanymi drewienkiem na papier, nazwałabym religijnym romantykiem. Chodzi tutaj nie tylko o tematyczną religijność, o to że są to przeważnie głowy apostołów i świętych. Oczywiście że sam ten temat narzuca dążenie do oddania wielkości. Ale każda epoka inaczej rozumie wielkość. [...] Dobrowolski jest chyba też romantykiem, ale zupełnie innego gatunku. Wraca do plastycznej, bryłowatej wystylizowanej formy, o dużej poetyckiej wyrazistości. Rozmarza, a równocześnie nie pozostawia wątpliwości, że chodzi tu nie o impresje, że sztuka jego w ogóle nie ma nic wspólnego z impresjonizmem, z ,wrażeniowością” że oddaje konkretny byt, pełną i pogodną prawdę istnienia. [...] Turkiewicz jest bardzo dekoracyjny, miękki i śpiewny w rysunku. Ale najtrudniejszy do rozgryzienia jest Kościałkowski (,Marian”). Zaskakuje zrazu dzikim i porwanym rysunkiem o nieokiełznanych formach, nie wiadomo czy opartych na całkowitej abstrakcji, czy tylko na częściowej, czy też w ogóle nie jest to abstrakcja, lecz dziwacznie przeinaczony obraz świata, niekiedy wzmocniony realistycznymi wtrętami. Niewątpliwie jest w tym fantazja, żywa i szumiąca. Ale jest w tej fantazji nuta neurotyczna $[\ldots]^{98}$.

W recenzji Zahorskiej znalazły się ilustracje: M. Bohusz-Szyszko, Św. Jan; Z. Turkiewicz, Niebieski akt; M. Kościałkowski, Kompozycja; A. Dobrowolski, Wakacje oraz T. Ilnicki, Mrówka. Wystawę dopełniały tkaniny, kilimy i ceramiki z Polski ${ }^{99}$.

13-21 marca, Central Hall, Londyn

Doroczna wystawa filatelistyczna „Stampex”. Wśród zaprezentowanych znalazły się znaczki z Polski, na stoisku zorganizowanym przez Ars Polona - głównie znaczki z okresu PRL. Osobno zainstalowano dwa stoiska polskich filatelistów z Londynu: Leona Laufera i Z. Bokiewicza, kierownika „Continental Stamp Supplies Ltd."

15 marca, Polska YMCA, 46/47 Kensington Gdns Square, Londyn Wycieczka artystyczna Polskiej YMCA do Courtauld Institute, z odczytem Mariana Bohusza-Szyszko o malarstwie francuskim z końca XIX wieku ${ }^{101}$.

18 marca, Polska YMCA, 46/47 Kensington Gdns Square, Londyn

Odczyt architekta R. Rudzińskiego pt. „Wielki artysta-architekt Stanisław Noakowski — życie i twórczość"102.

19 marca - 7 kwietnia, A.I.A. Gallery, Lisle Street, Londyn

\footnotetext{
${ }^{98}$ S. Zahorska, Rozdroża malarstwa, W 1959 nr 21(686), s. 6.

${ }^{99}$ A. Drwęska, Czarno-biate gamy, DPDŻ 25.03.1959, s. 3.

${ }^{100}$ J. B., Wystawa filatelistyczna, OT. Dodatek Ilustrowany $1959 \mathrm{nr}$ 27, s. 1, 4.

${ }^{101}$ Odczyty i wystawy, TP 1959 nr 7, s. 12.

102 Tamże.
} 
Wystawa „Continental British School of Painting” (Kontynentalno-Brytyjska Szkoła Malarska), która wcześniej pokazywana była w Wakefield Gallery i Bradford. Wystawa prezentowała prace malarzy brytyjskich, przybyłych z kontynentu, których malarstwo zachowało cechy odrębne od miejscowego, angielskiego. Wśród dziesięciu wystawionych malarzy, sześciu było Polakami: Marek Żuławski, Józef Herman, Jankiel Adler, Henryk Gotlib, Zdzisław Ruszkowski i Piotr Potworowski. Z recenzji Alicji Drwęskiej:

Najdłużej mieszka w Anglii Marek Żuławski — przyjechał już w roku 1936 i bodajże w jego pracach najbardziej można odczuć wpływ nie tylko tutejszego klimatu i atmosfery, także i malarstwa, a zwłaszcza Johna Pipera. Jest to oddźwięk dość daleki — jednak istnieje pewne pokrewieństwo kolorytu i koncepcji z dodatkiem wstrzemięźliwości formy oraz jasności kompozycji, która u Żuławskiego jest wyraźnym i dodatnim wpływem kubizmu francuskiego. [...] Józef Herman, jeden z najbardziej popularnych malarzy w Anglii — obrazy jego sprzedawane są zwykle jeszcze „na pniu” — przesiąkł również atmosferą górniczych walijskich miasteczek, lecz jeszcze głębszy wpływ wywarł na niego wcześniejszy, kilkuletni pobyt w Belgii i twórczość Permeke. [...] Zmarły w 1949 roku Jankiel Adler stworzył w Szkocji swą szkołę, a piętno jego indywidualności łatwo można rozpoznać choćby np. w pracach Colquhoun'a, McBryde'a i innych. Adler był przedziwnym połączeniem chasydzkiego mistycyzmu i głębokiej zachodnioeuropejskiej kultury, a obrazy jego, piękne i raczej radosne w swym kolorycie, o wyszukanej fakturze, mają logiczną, jasną strukturę oraz głębię wewnętrznej treści. [...] Gotlib, Potworowski, Ruszkowski wywodzą się z postimpresjonizmu francuskiego, a przede wszystkim z Bonnard'a. Gotlib, najstarszy wiekiem, pozostał mu najbliższy — jest mniej poetycki i wykwintny, natomiast bardziej sensualny i gorący w swym kolorycie. Ruszkowski, spokojny, powściągliwy i chłodniejszy w barwie, o tonacjach szlachetnych i niższych, ogranicza formę - raczej płaską - wyraźnym konturem, tworząc jakby pewien dekoracyjny nieco wzór. Jednakże w jego Pejzażu z Antibes, kształt jest mniej ostro określony i przestrzeń zbudowana jest plamami koloru. Obydwaj malarze, Gotlib i Ruszkowski mieli szkołę na Hampsteadzie i wychowali wielu młodych malarzy londyńskich. [...] Potworowski, będąc profesorem w Arts College w Corsham, również wywarł duży wpływ na rozwój swych pupilów i gorących wielbicieli jego twórczości, którzy nawet za bardzo malują „pod Potworowskiego”. Na wystawie w „A.I.A.” jego cztery obrazy pochodzą z różnych okresów, lecz wszystkie posiadają niezwykły poetycki urok, i mimo, że prawie abstrakcyjne, są jakby kwintesencją istoty pejzażu, postaci, czy przedmiotów, które artysta odtwarza, a raczej przetwarza. Kolor Potworowskiego, jest lekki, subtelny, wyszukany, obrazy jego mają świetlistość, przestrzenność a jednocześnie niepokojącą atmosferę, jakby magiczną i tajemniczą ${ }^{103}$.

22 marca, Polska YMCA, 46/47 Kensington Gdns Square, Londyn Wycieczka artystyczna Polskiej YMCA do National Gallery z prelekcją Mariana Bohusza-Szyszko o linearyzmie i malarskiej szkole włoskiej w XV wieku ${ }^{104}$.

Marzec, Polish Programmes BBC, Londyn

Audycja Marka Żuławskiego pt. „Corbusier”. „Round the Galleries” nr $44^{105}$.

25 marca - 11 kwietnia, Drian Gallery, 7 Porchester Place, Marble Arch, Londyn Wystawa malarstwa abstrakcyjnego Edgard Pillet z Paryża ${ }^{106}$.

103 A. Drwęska, Continental-British, TP 1959 nr 13, s. 13. Recenzja ilustrowana pracami Hermana i Adlera.

${ }^{104}$ Odczyty i wystawy, TP 1959 nr 8, s. 15.

${ }^{105}$ AE, MŻ, M. Żuławski, „Corbusier”, mps. 5 k.

${ }^{106}$ J. W. Sienkiewicz, Polskie galerie sztuki w Londynie..., s. 273. 
5 kwietnia, Polska YMCA, 46/47 Kensington Gdns Square, Londyn Prelekcja z filmem Francja romańska ${ }^{107}$.

5 kwietnia, Polska YMCA, 46/47 Kensington Gdns Square, Londyn Wycieczka artystyczna Polskiej YMCA do Tate Gallery z prelekcją Mariana Bohusza-Szyszko ${ }^{108}$.

8 kwietnia, Gospoda Kombatantów, 18 Queens Gate Terrace, Londyn Wystawa (pokaz?) artystycznych kukieł — rzeźb wykonanych przez Danutę Gierc (Giercuszkiewicz): Kot w butach, Skrzaty, Celadon, Woźnica Kufel ${ }^{109}$.

Kwiecień, New Art Centre, Sloane Street, Londyn Wystawa miniaturowych rzeźb Ireny Kunickiej z Kazimierza nad Wisłą ${ }^{110}$.

10-30 kwietnia, Hause der Begegnung, Monachium Wystawa ZPP w Wielkiej Brytanii pt. „Polnische Kunst in England”, wcześniej pokazywana w Grabowski Gallery ${ }^{111}$.

11 kwietnia - 2 maja, Grabowski Gallery, 84, Sloane Avenue, Chelsea, Londyn Trzecia wystawa w Galerii Grabowskiego. Pokazano 25 obrazów Tadeusza Ilnickiego oraz angielskiego malarza P. Woollarda. Z recenzji Alicji Drwęskiej:

Ilnicki obdarzony jest żywą imaginacją i dziecinną świeżością widzenia, skojarzonymi z inteligencją oraz świadomością dojrzałego artysty. Jego symboliczne zwierzęta: $P a$ jąk, Dzik, Kogut, jego Sztuczny kwiatek są prawie dziecinnie naiwne — lecz jakże pełne malarskiej i poetyckiej treści. To samo można powiedzieć o jego kompozycjach abstrakcyjnych. [...] Prace Ilnickiego w swym nastroju, w swej sugestywności przypominają mi malarstwo Klee'a ${ }^{112}$.

Sprawozdanie i reprodukcje prac — Muszka, Wczoraj, Dinosaur — zamieściło „Oblicze Tygodnia”, kreśląc biografię Ilnickiego. Prace Ilnickiego „oscylujące między abstrakcją a świadomym prymitywem" ${ }^{\text {"113 }}$. Z recenzji S. Zahorskiej:

Ilnicki, który wystawiał w galerii Grabowskiego, jest świetnym malarzem. Już poprzednie jego wystawy wskazywały zarówno na doskonałą znajomość métier, na wyczucie wartości barwnych, na świetną fakturę. Mało kto jak Ilnicki potrafi różnicować płaszczyzny i nadawać im niesłychaną wyrazistość przez sposób kładzenia farb, przez gładzizny i szorstkość, wytarcia plam i układ tłustych płaszczyzn barwnych. W tym bogactwie stopniowań i kolorystycznych i fakturowych Ilnicki należy do najlepszych malarzy na emigracji; niewielu angielskich może się z nim mierzyć. [...] Nie rozumiem tylko po co Ilnicki przeskakuje w niektórych swoich obrazach do czystej niemal, pierwotnie kubistycznej, geometrycznej abstrakcji. Rozporządzając takim bogactwem ekspresji i umiejętności jej wydobycia, po co zaczyna szkółkę od nowa? Przecież stać go

${ }^{107}$ Odczyty i wystawy, TP 1959 nr 8, s. 15.

${ }^{108}$ Odczyty i wystawy, TP $1959 \mathrm{nr} 10$, s. 15.

${ }^{109}$ Odczyty i wystawy, DPDŻ 8.04.1959, s. 4.

${ }^{110}$ A. Drwęska, Miniatury w kamieniu i drzewie, DPDŻ 23.04.1959, s. 3.

${ }^{111}$ J. Baranowska, Rozmowa z... Sekretarzem Zrzeszenia Plastyków Polskich..., s. 11.

112 A. Drwęska, Poetyckie symbole, DPDŻ 20.04.1959, s. 3 - tam reprodukcja obrazu Wczoraj.

${ }^{113}$ (k.), Obrazy T. Ilnickiego w Galerii Grabowskiego, OT. Dodatek Ilustrowany $1959 \mathrm{nr} 29$, s. b. 
na rzeczy stokrotnie bardziej złożone, na subtelności w formie, kolorycie i fakturze bardziej interesujące niż zestaw kwadratów. [...] Oczywiście taka choroba przy zdrowym organizmie przechodzi szybko i - nie powraca ${ }^{114}$.

Kwiecień, Drian Gallery, 7 Porchester Place, Marble Arch, Londyn Wystawa malarstwa Cyrila Hamersmy ${ }^{115}$.

12 kwietnia, Polska YMCA, 46/47 Kensington Gdns Square, Londyn Wycieczka artystyczna Polskiej YMCA do Victoria \& Albert Museum z prelekcją Mariana Bohusza-Szyszko pt. „Akwarela angielska" ${ }^{\text {"116. }}$

Kwiecień, Polska YMCA, 46/47 Kensington Gdns Square, Londyn Indywidualna wystawa fotografii Maksymiliana Myszkowskiego z Poznania pt. „Tatry"117. Wystawę otworzył L. Stanton-Święcicki ${ }^{118}$.

W 75 kompozycjach, niekiedy bardzo dobrze wykonanych technicznie artysta-fotograf dał jakby sentymentalną wycieczkę od Zakopanego poprzez Kuźnice i drogą do Czarnego Stawu, wśród jakże charakterystycznych postaci góralskich i na jakże wspaniałym tle krajobrazów górskich ${ }^{119}$.

Kwiecień, Polish Programmes BBC, Londyn

Audycja Marka Żuławskiego pt. „Gruber, New American Painting at The Tate”. „Round the Galleries” $\mathrm{nr} 45^{120}$.

13 kwietnia, Grabowski Gallery, 84 Sloane Avenue, Chelsea, Londyn Zrzeszenie Plastyków Polskich w Wielkiej Brytanii wznowiło zwyczaj spotykania się co kilka tygodni dla wymiany poglądów na sztukę. Zebranie pn. „Problemy sztuki współczesnej” zorganizowane zostało przy pomocy Mateusza Grabowskiego, który zamierzał w nowopowstałej Galerii stworzyć ośrodek dyskusyjny na tematy współczesnej sztuki ${ }^{121}$. Spotkaniu przewodniczył Tadeusz Muszyński. Dyskusję rozpoczął Marian Bohusz-Szyszko, który „wspomniał m.in. o «bakcylach» naturalizmu, ekspresjonizmu i wreszcie formizmu w sztuce, dominujących w różnych epokach"122. W dyskusji wzięli udział ponadto: Stanisław Frenkiel i Marek Łączyński.

Ogólne zainteresowanie wzbudziły pod koniec wypowiedzi jednego z malarzy z Warszawy, z których wynikało, że sprzedaje się tam właśnie obrazy abstrakcyjne, że natomiast «Szmira nie popłaca», a plastycy pomimo ciężkiego życia są pomysłowi i weseli. [...] Spotkanie to przekonało chyba obecnych, że warto w przyszłości tego rodzaju zebrania powtarzać, zapraszając na nie również krytyków, dziennikarzy i tych wszystkich dla których polska twórczość w dziedzinie plastyki nie jest jedynie pojęciem historycznym ${ }^{123}$.

${ }^{114}$ S. Zahorska, Rozdroża malarstwa, W 1959 nr 21(686), s. 6.

115 AE, HN, Drian, Cyril Hamersma [zaproszenie na wystawę].

${ }^{116}$ Odczyty i wystawy, TP $1959 \mathrm{nr} 11$, s. 15.

${ }_{117}$ Biuletyn. Stowarzyszenie Fotografików Polskich — Polska YMCA, Londyn [1959] nr 1, s. 26.

${ }^{118}$ Notatki, Gazeta Niedzielna 1959 nr 16(517), s. 9 - tam reprodukcja: T. Ilnicki, Mrówka.

119 (n), Polskie życie kulturalne. Warsztaty malarskie i literackie, OB $1959 \mathrm{nr} 16, \mathrm{~s} .5$.

${ }^{120}$ AE, MŻ, M. Żuławski, „Gruber, New American Painting at The Tate”, mps, 5 k.

121 (k.), Plastycy dyskutuja, OT. Dodatek Ilustrowany 1959 nr 29, s. b.

122 (mc), Rozmowy plastyków, OB 1959 nr 17, s. 6.

${ }^{123}$ Tamże. 
19 kwietnia, Polska YMCA, 46/47 Kensington Gdns Square, Londyn Wycieczka artystyczna Polskiej YMCA do British Museum z wykładem Mariana Bohusza-Szyszko pt. „Syria”, ${ }^{24}$.

21 kwietnia - 5 maja, Drian Gallery, 7 Porchester Place, Marble Arch, Londyn Wystawa 30 prac kinetycznych żydowskiego malarza Yaacova Agama, zatytułowana Movable and Transformable Paintings. Paintings in Movement ${ }^{125}$. Wystawie towarzyszył folder z tekstem krytyka sztuki Michel Seuphor.

Pokazane przez Halimę Nałęcz prace Agama należały do wczesnej fazy twórczości artysty i zawierały ładunek doświadczeń i osiągnięć wszystkich dotychczasowych kierunków sztuki bezprzedmiotowej, z neoplastycyzmem, konstruktywizmem i suprematyzmem na czele ${ }^{126}$.

26 kwietnia - maj, Polska YMCA, 46/47 Kensington Gdns Square, Londyn Wystawa malarstwa ojca i syna: Mariana Bohusz-Szyszko oraz Andrzeja Bohusza-Szyszko ${ }^{127}$. Otwarcia wystawy dokonał amb. Edward Raczyński. Z recenzji:

Młodemu Bohuszowi nie brak na pewno talentu — brak natomiast jeszcze doświadczenia malarskiego i skrystalizowania zamierzeń twórczych ${ }^{128}$.

W „Obliczu Tygodnia” reprodukowano płótna M. Bohusza-Szyszko: Zdjęcie z Krzyża, Portret p. J. Chmurzyńskiej, Ukrzyżowanie I, bez tytułu, oraz dwa nienazwane obrazy A. Bohusza-Szyszko. Większą recenzję zamieścił „Tydzień Polski”. Zauważono, że Marian Bohusz-Szyszko prezentował wyłącznie portrety, a Bohusz-Szyszko jr, pokazał abstrakty.

Wcześniejsze z nich jak autoportret demonstrują styl z jakim opuścił Polskę: są modelowane kolorem, a nie światłocieniem, czerni nie ma na lekarstwo w tych obrazach, lecz również nie ma i deformacji. Jest w nich natomiast podobieństwo i charakter. [...] Prace z tego okresu Bohusza-Szyszki są może najbardziej szczęśliwie zrównoważone. Kolorystą Bohusz-Szyszko pozostał, lecz późniejsze portrety [...] wskazują, że program ten stał mu się z biegiem czasu za ciasny: farba kładziona coraz grubiej i brutalniej, coraz intensywniejsza w tonie, staje się elementem który mówi, ma wartość uczuciową i przemienia się w coś więcej niż środek budowy obrazu: dąży wręcz do rozbicia tej jego budowy ${ }^{129}$.

3 maja, Polska YMCA, 46/47 Kensington Gdns Square, Londyn Wycieczka artystyczna Polskiej YMCA do National Gallery z odczytem Mariana Bohusza-Szyszko o Velázquezie ${ }^{130}$.

6-27 maja, Grabowski Gallery, 84 Sloane Avenue, Chelsea, Londyn

\footnotetext{
${ }^{124}$ Odczyty i wystawy, TP 1959 nr 12, s. 15.

125 M. Wykes-Joyce, Drian Galleries, s. 15; J. W. Sienkiewicz, Polskie galerie sztuki w Londynie, s. 50.

${ }^{126}$ J. W. Sienkiewicz, Polskie galerie sztuki w Londynie, s. 51; Agam at The Drian Gallery, Apollo $1959 \mathrm{nr}$ 411, s. 149.

${ }^{127}$ Odczyty i wystawy, DPDŻ 24.05.1959, s. 4; J. W. Sienkiewicz, Marian Bohusz-Szyszko, s. 133.

${ }^{128}$ (L.), ...i w YMCA-e: ojciec...; ... i syn Andrzej, OT. Dodatek Ilustrowany $1959 \mathrm{nr}$ 32, s. d-e.

129 [S. Arvay] S. A., Marian Bohusz-Szyszko i syn, TP 1959 nr 18, s. 11 - tam reprodukcja jednego z obrazów M. Bohusza-Szyszko. Informacja o wystawie także: S. Zahorska, Wystawa Bohusza-Szyszko, W 1959 nr 25(690), s. 5.

${ }^{130}$ Odczyty i wystawy, TP $1959 \mathrm{nr} 14$, s. 15.
} 
Wystawa malarstwa religijnego Mariana Bohusza-Szyszko (odbywająca się w tym samym czasie, co wystawa w Polskiej YMCA) ${ }^{131}$. Malarz pokazał 29 obrazów, z czego 22 o charakterze religijnym (reszta: autoportret, dwie martwe natury, trzy portrety i akt). Przedmowę do katalogu napisała Marion Milner. Wystawę otworzył Sir William Coldstream z Slade School of Fine Art przy University College w Londynie ${ }^{132}$.

Świadom faktu, że sekret sztuki religijnej w ciągu ostatniego półtora stulecia zaginął, Bohusz-Szyszko mocą drastycznej redukcji wszystkiego co było konwencjonalnym balastem w tej, zdawałoby się, kompletnie wyeksploatowanej dziedzinie dał rzeczy przekonywujące i szczere, klimatem duchowym bliskie działaniu bizantyjskiej ikony. Formalnie obrazy te są niepokojące: jest w nich nie zawsze szczęśliwie rozwiązany konflikt dwu przeciwstawnych dążeń: do logicznej harmonijnej konstrukcji obrazu i z drugiej strony do maksimum siły wyrazu ${ }^{133}$.

Recenzja wystawy, pióra Erica Newtona ukazała się w „Manchester Guardian” —

Bohusz-Szyszko jest ekspresjonistą. Dominuje u niego pasja i impuls. Te dwie cechy, często nadużywane i pokrywające nieporządek wewnętrzny artysty, przez SzyszkoBohusza są stosowane nie tylko przekonywująco, ale ze szlachetnym gestem wielkiego artysty. [...] Niedostatki malarza są drobne i wybaczalne, osiągnięcia zaś godne podziwu, a w kilku wypadkach zadziwiające świetnością. Szyszko-Bohusz operuje gestem pełnym wyrazu, kolorem, który przyciąga wzrok będąc zawsze trafnie użyty i maluje pociągnięciami pędzla tak szerokimi na ile tylko pozwala technika malarska bez zamazania tematu. Jego prototypem jest Soutine, ale Soutine nigdy nie podejmował się takich wielkich tematów jak Nawrócenie św. Pawta albo Zestanie Ducha Świętego ${ }^{134}$.

W recenzji w „Time and Tide” z 23 maja, ten sam krytyk napisał:

Wśród współczesnych ekspresjonistów, znam tylko dwóch czy trzech — nie więcej którzy by potrafili łączyć wizję z techniką na tak poważny użytek i bez większych potknięć. Takie malarstwo wymaga czegoś bliskiego natchnieniu; a natchnienie nie da się odkręcać jak kurek $^{135}$.

Stefan Legeżyński napisał w „Gazecie Niedzielnej”:

Choć Bohusz używa środków całkowicie nowoczesnych, to treść religijna jego obrazów w całej mocy promieniuje z nich na widza. Siła, którą tchną te obrazy, powoduje że nasz podziw i zrozumienie sztuki Bohusza rośnie z wystawy na wystawę ${ }^{136}$.

Wystawa Bohusza-Szyszko okazała się nie tylko artystycznym, ale też finansowym sukcesem ${ }^{137}$. Najobszerniejsza recenzja ukazała się w „Wiadomościach”, a jej autorką była Stefania Zahorska:

Wystawa w Galerii Grabowskiego skupiła niemal cały życiowy dorobek Bohusza. Była to wystawa owoców ży c i a bohaterski e go, poświęconego jednej tylko idei (o dwóch twarzach), prawdziwej g wiazdy przewodniej; obrazy Bohusza są równocześnie religijnym wyznaniem wiary i wyznaniem wiary malarskiej. [...] Naj-

${ }^{131}$ J. W. Sienkiewicz, Marian Bohusz-Szyszko, s. 132.

132 (D.D.), Wystawa Bohusza-Szyski [sic!], DPDŻ 18.05.1959, s. 3.

133 [S. Arvay] S. A., Marian Bohusz-Szyszko i syn, s. 11.

${ }^{134}$ Wielki Artysta, DPDŻ 25.05.1959, s. 3; K. Kostynowicz, Marian Szyszko-Bohusz w Galerii Grabowskiego, OT. Dodatek Ilustrowany $1959 \mathrm{nr}$ 32, s. d-e.

${ }^{135}$ Collector, W oczach Zachodu: Sukces Bohusza-Szyszki, W $1959 \mathrm{nr}$ 24(689), s. 5.

136 S. L., Marian Bohusz-Szyszko w Galerii Grabowskiego, Gazeta Niedzielna $1959 \mathrm{nr}$ 16(517), s. 9.

${ }^{137}$ Notatki, Gazeta Niedzielna 1959 nr 26(527), s. 6. 
ogólniejszym mianownikiem religijnych obrazów Bohusza jest zachwyt nad Cudem. Cudem Zwiastowania i Narodzin, cudem Chrystusa chodzącego po ziemi wśród ludzi, nauczającego, zwiastującego, i nade wszystko cudem straszliwym i krwawym Ukrzyżowania. Przeniknąć naturę tego Cudu, znaczy przeżyć go mistycznie, znaleźć dla niego wyraz, znaczy niejako sprostać mu malarsko. Znaczy to - oderwać się całkowicie od racjonalistycznych przesądów: to jest możliwe a to jest niemożliwe, to mogło się stać a to nie mogło. [...] Ukrzyżowanie, to temat stale powtarzający się w twórczości Bohusza, jakby w nim widział r o z w i ą z a n i e całej boskiej tragedii. Jedna z pierwszych wersji, to ta, gdzie Chrystus jest niemal całkowicie bezcielesny, białe, czarne i brązowe linie podkreślają napięte żebra, ciało Ukrzyżowanego nie ciąży, unoszone jest jakby straszliwym dynamizmem cierpienia i stającego się Odkupienia. [...] Forma tworzy się u Bohusza przez kolor. Jest to forma płaska, z bardzo nieznacznymi stopniowaniami w występowaniu i wstępowaniu, tylko o tyle o ile symbol postaci wymaga nieco plastycznego ukształtowania i o ile kolor wybiega na przód lub w tył. Są jednak takie obrazy, głównie gwasze, częściowo obrysowane konturem liniowym, całkowicie płaskie, jednoplanowe. Mam wrażenie, że gubi się w nich kolorystyczne bogactwo Bohusza, ekspresja się upraszcza, symbol staje się bardziej tematyczny, mniej malarski. [...] Wydaje mi się że owo bezapelacyjne odrzucenie głębi w obrazie nie jest niczym uzasadnione. Obrazy płaskie idealnie, i to nie tylko w sensie dyscypliny kolorów, lecz w sensie unikania głębi, stają się przeładowane, zdradzają swą szczupłość, bo mieszczą tylko tyle ile da się zmieścić w czterech listwach ramy ${ }^{138}$.

Recenzję Zahorskiej ilustrują fotografie trzech prac Bohusza: Upadty aniot, Ukrzyżowanie, Portret p. $M$.

7-23 maja, Drian Gallery, 7 Porchester Place, Marble Arch, Londyn Wystawa malarstwa i witraży Niny Tryggvadittor z Islandii ${ }^{139}$.

Maj, Smithsonian Institution, Waszyngton

Przygotowana w Wielkiej Brytanii dla Smithsonian Institution wystawa „British Artist Craftmen” rozpoczęła podróż po Stanach Zjednoczonych. Wśród ponad 175 obiektów znalazły się prace Polaków:

Najbardziej imponującymi pracami na wystawie są rzeźby, spośród których wiele jest dla kościoła, w tym Majestras Sir Jacoba Epsteina [...] i pokaźne emaliowane drzwi arki dla Synagogi autorstwa Stefana Knappa ${ }^{140}$.

10 maja, Polska YMCA, 46/47 Kensington Gdns Square, Londyn Wycieczka artystyczna Polskiej YMCA do Muzeum Historii Naturalnej z prelekcją Mariana Bohusza-Szyszko ${ }^{141}$.

10-31 maja, Hause der Begegnung, Hamburg Wystawa ZPP w Wielkiej Brytanii pt. „Polnische Kunst in England”, wcześniej pokazywana w Grabowski Gallery i Monachium ${ }^{142}$.

17 maja, Polska YMCA, 46/47 Kensington Gdns Square, Londyn

\footnotetext{
${ }^{138}$ S. Zahorska, Wystawa Bohusz-Szyszki, W 1959 nr 25(690), s. 5 [podkr. - S. Z.]. stawe].

139 AE, HN, Drian, Tryggvadottir. Recent Paintings and Stained Glass [zaproszenie na wy-

${ }^{140}$ Bristish Artist Craftmen, The Studio 1969 (maj), s. 151 [tłum. — red].

${ }^{141}$ Odczyty i wystawy, TP $1959 \mathrm{nr} 15$, s. 15.

142 J. Baranowska, Rozmowa z... Sekretarzem Zrzeszenia Plastyków Polskich..., s. 11.
} 
Wycieczka artystyczna Polskiej YMCA do British Museum z prelekcją Mariana Bohusza-Szyszko pt. „Kultury archaicznej Europy”"143.

24 maja, Polska YMCA, 46/47 Kensington Gdns Square, Londyn Wycieczka artystyczna autokarem Polskiej YMCA do Windsoru, z przewodnikiem Marianem Bohuszem-Szyszko ${ }^{144}$.

24 maja, „Wiadomości”, Londyn

Ukazał się bogato ilustrowany artykuł Stefanii Zahorskiej — jednej z najważniejszych polskich krytyków sztuki — pt. Bezdroża malarstwa poświęcony współczesnej sztuce abstrakcyjnej oraz polskim wystawom w Wielkiej Brytanii ${ }^{145}$ :

Dzisiejszy abstrakcjonizm niewiele ma wspólnego z dawnym, kubistycznym. Kierunek rozrósł się, wytworzył wiele odmian, nie ogranicza się już do form geometrycznych; dążenie do równowagi i wyważonej kompozycji ukrył pod dowolnością przygodnych, często mechanistycznie osiąganych form, jest łatwy i szerzy się jak wietrzna ospa. Najzabawniejsze jest że publiczność, w zasadzie niechętna i nie rozumiejąca sensu i celu tego nowego wyrazu sztuki, przyzwyczaiła się do niego, zaczyna gardzić spokojnym burżuazyjnym realizmem i domaga się irytującego ją dodatku abstrakcjonizmu, jak musztardy w restauracji, jak ostrego sosu do mięsa. Szczególnie Anglicy. Niezrozumiałość obrazu staje się niejako poręką jego głębokich treści. Nikt nie umiałby ich nazwać, ale przyjemnie jest wiedzieć że są ${ }^{146}$.

25 maja[?], Grabowski Gallery, 84 Sloane Avenue, Chelsea, Londyn Wieczór dyskusyjny nad referatem przybyłego z Polski malarza Stanisława Kostynowicza, pt. ,Socrealizm i formalizm w Polsce", ${ }^{4}$.

25 maja - 6 czerwca, Drian Gallery, 7 Porchester Place, Marble Arch, Londyn Wystawa malarstwa Ulrico Schettini, Włocha mieszkającego w Londynie i Niemca Willy Tirra $^{148}$.

30 maja - 20 czerwca, Grabowski Gallery, 84 Sloane Avenue, Chelsea, Londyn Wystawa 40 obrazów (olejów, gwaszy, temper, pasteli i w technice mieszanej) oraz 60 ceramik i rzeźb w wosku, terakocie i laku chińskim Stanisława „Kuby” Kostynowicza, który przyjechał z Polski na zaproszenie brata Czesława, najbardziej znanego polskiego perkusisty w Londynie $^{149}$. Prace głównie o tematyce religijnej, w tym cykl Madonny ${ }^{150}$. Fotografie zamieściło „Oblicze Tygodnia”, tam też recenzja Marka Łatyńskiego:

${ }^{143}$ Odczyty i wystawy, TP 1959 nr 16, s. 15.

${ }^{144}$ Odczyty i wystawy, TP $1959 \mathrm{nr} 17$, s. 15.

${ }^{145}$ S. Zahorska, Bezdroża malarstwa, W 1959 nr 21(686), s. 6.

${ }^{146}$ Tamże.

${ }^{147}$ Ogłoszenie, DPDŻ 25.05.1959, s. 2.

148 AE, HN, Drian, Recent Paintings by Ulrico Schettini [folder wystawy], [London 1959]; Willy Tirr [zaproszenie na wystawę]; M. Wykes-Joyce, Drian Galleries, s. 24.

${ }^{149}$ (zkn), Malarz z Kraju w Galerii Grabowskiego, TP 1959 nr 17, s. 12; J. W. Sienkiewicz, Polskie galerie sztuki $w$ Londynie, s. 281.

${ }^{150}$ M. B. S., Obrazy St. Kostynowicza - malarza z Kraju w Galerii Grabowskiego, TP 1959 nr 32, s. 9 
Artysta nie robi nic aby przeciągnąć widza na swoją stronę — żadnych łatwizn — żadnego pochlebstwa dla zwiedzającego. Wprost przeciwnie, stawia on nas wobec faktu o którym mówi: „mój świat” ${ }^{\text {,151. }}$

\section{S. Legeżyński w „Gazecie Niedzielnej”:}

38 jego obrazów, niedużego formatu, zapełniło dwie sale wystawy. Są to abstrakcje o wybitnym piętnie indywidualnym i specjalnie świeże na tle londyńskim. Elementy polskie, a właściwie sztuki polskiej, która posiada piękne wiekowe tradycje, tkwią swymi korzeniami w kompozycjach Kostynowicza ${ }^{152}$.

W „Tygodniu Polskim” ukazał się apel Mariana Bohusza-Szyszko o kupowanie prac malarza, który zapadł na chorobę ${ }^{153}$.

Razem z obrazami Kostynowicza pokazano prace — oleje, rysunki i gwasze - Józefa (Josepha) Levina Surconsciencilism ${ }^{154}$.

\section{Wiosna, Polska}

Wystawa grafiki Marka Łączyńskiego w Zielonej Górze, Poznaniu, Chorzowie, Szczecinie i Wrocławiu. Z recenzji krajowych:

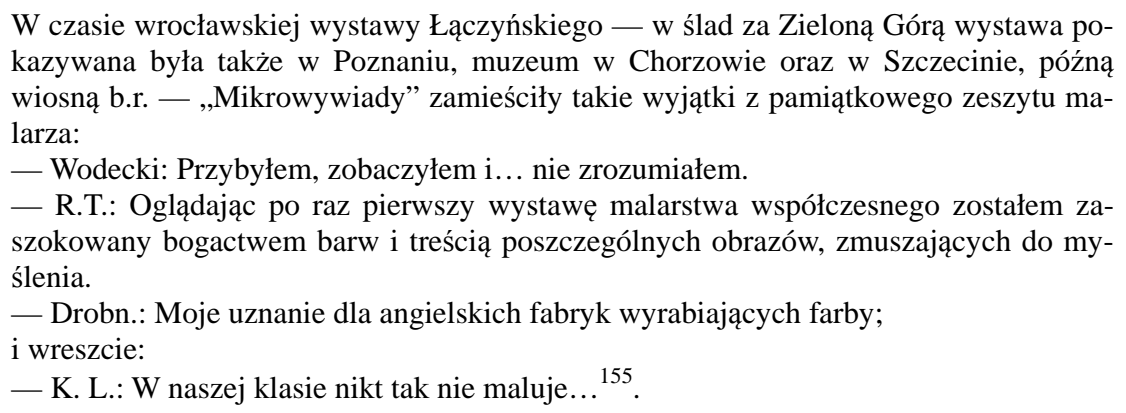
kazywana była także w Poznaniu, muzeum w Chorzowie oraz w Szczecinie, późną wiosną b.r. — „Mikrowywiady” zamieściły takie wyjątki z pamiątkowego zeszytu malarza:

— Wodecki: Przybyłem, zobaczyłem i... nie zrozumiałem.

— R.T.: Oglądając po raz pierwszy wystawę malarstwa współczesnego zostałem zaszokowany bogactwem barw i treścią poszczególnych obrazów, zmuszających do myślenia.

— Drobn.: Moje uznanie dla angielskich fabryk wyrabiających farby;

i wreszcie:

- K. L.: W naszej klasie nikt tak nie maluje... ${ }^{155}$.

31 maja, Polska YMCA, 46/47 Kensington Gdns Square, Londyn

Wycieczka artystyczna Polskiej YMCA i zwiedzanie Royal Academy of Arts — Piccadilly, z przewodnikiem, Marianem Bohuszem-Szyszko ${ }^{156}$.

31 maja - 28 czerwca, Polska YMCA, 46/47 Kensington Gdns Square, Londyn III Światowa Wystawa Fotografiki Polskiej na Obczyźnie. Pierwsze ogłoszenie o wystawie ukazało się $\mathrm{w}$ marcu w prasie emigracyjnej w wielu krajach ${ }^{157}$. Wystawę otworzył Adam M. Arvay ${ }^{158}$. Wystawiało 34 fotografów polskich mieszkających na emigracji. Pokazano 176 eksponatów, w tym 136 fotografii czarno-białych i 40 kolorowych prze-

${ }^{151}$ M. Łączyński, Od szczątkowego realizmu do abstrakcji. Wystawa „Kuby” Kostynowicza w Galerii Grabowskiego, OT. Dodatek Ilustrowany 1959 nr 35, s. d.

${ }^{152}$ S. L., Kuba Kostynowicz w Galerii Grabowskiego, Gazeta Niedzielna 1959 nr 24(525), s. 6; J. W. Sienkiewicz, Polskie galerie sztuki w Londynie, s. 281.

${ }_{153}$ M. B. S., Obrazy St. Kostynowicza..., s. 9 - tam zdjęcie malarza.

${ }^{154}$ Ogłoszenie, Gazeta Niedzielna 1959 nr 22(523), s. 12.

${ }^{155}$ J. L. Englert, Marek Łaczyński, DPDŻ 18.11.1959, s. 3.

${ }^{156}$ Odczyty i wystawy, TP $1959 \mathrm{nr} 18$, s. 15.

${ }^{157}$ Por.: Wystawa fotografiki polskiej na obczyźnie, Syrena (Paryż) 1959 nr 11, s. 11; Wystawa fotografiki polskiej na uchodźstwie, Kultura 1959 nr 4(138), s. 129-130; Odczyty i wykłady, DPDŻ 27.05.1959, s. 4.

${ }^{158}$ Odczyty i wystawy, TP $1959 \mathrm{nr} 18$, s. 15. 
źroczy. Przygotowanie wystawy trwało dziewięć miesięcy. W jury kwalifikacyjnym byli: E. Baziuk, T. M. Kupiec, L. S. Stanton-Święcicki, M. Wondraczek i L. Kinasz. Wystawę otworzyli: B. T. Lesiecki, dyr. Polskiej YMCA i Władysław Marynowicz, prezes Stowarzyszenia Polskich Fotografików oraz Adam M. Arvay, senior polskich fotografików na obczyźnie. Z Londynu wystawiali: H. Bartoszewicz, E. Baziuk, R. Berezowski, Z. Bohdanowicz, J. Delinikajtis, Z. W. Frank, P. Klausner, S. Kumoń, T. M. Kupiec, B. T. Lesiecki, J. S. Lewiński, [E. Wojtczak] Lucyfer, W. Marynowicz, S. J. Markiewicz, Ludwik Meller, M. Pohlman, W. Przeździecki, J. Schmidtke, W. Śledziewski, L. S. StantonŚwięcicki, Tomasz S. Stanton-Święcicki (junior), T. M. S. Sumorek, B. W. Trzeciecki, M. Wondraczek, L. Kinasz. Ludwik Meller pokazał portret z szalem, który w 1959 roku wygrał nagrodę „Model of the Year Competition” londyńskiego „Camera Club”,

Wystawa ostatnia porównana z wystawą zeszłoroczną wykazuje wyraźnie odsunięcie się od wzorów przedwojennych polskich, wyjście poza tradycje Bułhaka czy Wańskiego. Jeśli mało przypomina ona to - co się dzieje na kontynencie, to od angielskich wystaw różni się znacznie mniej. Usiłowanie aby skorzystać z angielskich doświadczeń jest jak najbardziej widoczne. [...] Im bliżej przyglądamy się tej wystawie - tym mniej ,emigracyjność” jej wydaje się określeniem słusznym. Odkrywamy w niej coraz więcej elementów, które się z Polski nie wywodzą ${ }^{160}$.

Przy okazji wystawy ukazał się w londyńskim piśmie „Amateur Photographer” artykuł S. J. Lewińskiego, ilustrowany siedmioma fotografiami ${ }^{161}$. W recenzji S. Legeżyńskiego:

Obecna wystawa posiadała oprócz fotografii artystycznych z Anglii — z czego większość od naszych naprawdę świetnych fotografików londyńskich - i Szkocji, również prace z Nowego Jorku, Lizbony, Monachium, Kopenhagi, Francji oraz Australii ${ }^{162}$.

Czerwiec, Atelier W. R. Szomańskiego, 73 Holland Road, Londyn Ostatnie spotkanie z cyklu „Czwartków Architektów, Artystów, Malarzy, Aktorów, Dziennikarzy, Grafików, Pisarzy, Poetów i Rzeźbiarzy”. Inicjatorem spotkań był Władysław Szomański, który początkowo (od 1952 r.) organizował nieregularne spotkania w kawiarni Dakowskiego lub „Kontiki”, a w końcu w swoim atelier przy 73 Holland Road. Z czasem przybrały one postać regularnych imprez i odbywały się przez siedem lat, aż do czerwca 1959 roku. Oprócz studia Szomańskiego, „Czwartki” gościły także w lokalach Jana Kępińskiego, Witka Szejbala, Halimy Nałęcz czy Tamary Karren. W roku 1983 znów za sprawą Szomańskiego idea spotkań odżyła — tym razem przeniesiono je do Sali w restauracji ,Łowiczanka” w POSK-u. W nowym miejscu zmieniła się nieco ich forma - spotkania wzbogacono prelekcjami, często ilustrowanymi slajdami (w marcu 1993 r. miał miejsce jubileuszowy „Setny Czwartek”) ${ }^{163}$.

7 czerwca, Polska YMCA, 46/47 Kensington Gdns Square, Londyn Wycieczka artystyczna Polskiej YMCA do National Gallery z prelekcją Mariana Bohusza-Szyszko, ,z uwzględnieniem poznania zbiorów dla przybyłych z Polski”, ${ }^{164}$.

${ }^{159}$ Biuletyn. Stowarzyszenie Fotografików Polskich — Polska YMCA, Londyn [1959] nr 1, s. 26; (M.P.), 34 fotografów w YMCA, DPDŻ 8.06.1959, s. 3.

${ }^{160}$ S. Arvay, Wystawa ,emigracyjna”...?, Biuletyn. Stowarzyszenie Fotografików Polskich — Polska YMCA, Londyn [1959] nr 1, s. 5.

${ }^{161}$ Notatki, Gazeta Niedzielna 1959 nr 24(525), s. 6.

${ }^{162}$ S. L., Światowa wystawa fotografiki polskiej, Gazeta Niedzielna 1959 nr 26(527), s. 6.

${ }^{163}$ J. Koźmiński, Bon vivant, DPDŻ — Relaks 1999 nr 70, s. I.

${ }^{164}$ Odczyty i wystawy, TP $1959 \mathrm{nr} 19$, s. 15. 
8/9-20 czerwca, Drian Gallery, 7 Porchester Place, Marble Arch, Londyn Wystawa malarska dwóch Anglików: Krome Barratta i Franka Fidlera ${ }^{165}$.

11 czerwca - 4 lipca, The Stone Gallery, Newcastle Wystawa malarstwa Marka Żuławskiego — „Recent Paintings by Marek Zulawski”, wcześniej pokazywana w Londynie ${ }^{166}$. Recenzja w „The Times”167.

13-14, 20-21 czerwca, Instytut Historyczny im. gen. Sikorskiego, 20 Princes Gate, Londyn

Druga w cyklu, doroczna wystawa prac dzieci i młodzieży ze szkół przedmiotów ojczystych w Wielkiej Brytanii oraz zakładów sióstr nazaretanek z Pitsford i ojców marianów z Fowley Court, pn. „Wystawa prac młodzieży szkolnej”" ${ }^{168}$. Prace konkursowe nadsyłane były do organizatorów, tj. czasopism dla dzieci: dodatek „Dziennik Polski dzieciom”, „Dziatwa”, „Gazeta Szkolna”" Zjednoczenia Polskiego S. Lis, a o roli i znaczeniu wystawy mówił przewodniczący Komitetu Wystawy — Marian Bulicz ${ }^{170}$.

14 czerwca, Polska YMCA, 46/47 Kensington Gdns Square, Londyn Wycieczka artystyczna Polskiej YMCA do National Gallery z prelekcją Mariana Bohusza-Szyszko ${ }^{171}$.

Czerwiec - lipiec, Gallery One, Londyn Wystawa malarstwa Franciszki Themerson.

Krytyka określiła obrazy Polki, Franciszki Themerson, wystawione w Gallery One, jako abstrakcje o dużym ładunku satyrycznym ${ }^{172}$.

Z recenzji Marka Żuławskiego dla BBC:

Istnieje pewne techniczne podobieństwo pomiędzy obrazami Fautriera a pracami Franciszki Themerson, która ma teraz wystawę w Gallery One. Oboje malują grubo białą farbą, którą później laserują przezroczystym kolorem. Ale Themerson traktuje farbę jak żywą materię rzeźbiarską, w której żłobi rysunek. Jest to jak gdyby nowoczesne malarstwo jaskiniowe pełne ludzkich postaci w niezrozumiałych sytuacjach. Ogromne głowy rysowane na pozór jak gdyby przez pięcioletnie dziecko mają jednak potężny wyraz jakiejś enigmatycznej tragikomedii ludzkiego istnienia. Tak Ionesco w teatrze, Franciszka Themerson w malarstwie stwarza fantastyczny mikrokosmos życia, który jest na pozór irracjonalny, ale przy bliższym zastanowieniu staje się przerażająco realny. Można powiedzieć, że Franciszka Themerson znalazła własny język do wyrażania niepokojących stanów i konfliktów ludzkiej duszy, ale w przeciwieństwie do Fautriera są to nastroje smutku, nostalgii i udręki, a nie radości. Kolor tych obrazów jest bogaty i świetlisty, ale

165 AE, HN, Drian, Paintings by Krome Barratt [zaproszenie na wystawę]; Fidler [folder wystawy], [London 1959]; M. Wykes-Joyce, Drian Galleries, s. 29.

${ }^{166}$ Recent Paintings by Marek Zulawski, [informator wystawy], 11 VI - 4 VII, Newcastle: The Stone Gallery, 1959

${ }^{167}$ [Correspondent], Derby Day as Frith Saw It, The Times, 28.06.1959.

${ }^{168}$ Wystawa prac młodzieży szkolnej, OB-S $1959 \mathrm{nr} 23, \mathrm{~s} .8$.

${ }^{169}$ L. B., Wystawa prac dzieci, DPDŻ 10.06.1959, s. 3; Będziem Polakami. Wystawa w Instytucie im. gen. Sikorskiego, DPDŻ 19.06.1959, s. 3.

${ }^{170}$ (p.h.), Wystawa prac młodzieży szkolnej, OB-S $1959 \mathrm{nr}$ 25, s. 5.

${ }^{171}$ Odczyty i wystawy, TP $1959 \mathrm{nr} 20$, s. 15.

${ }^{172}$ Notatki, Gazeta Niedzielna 1959 nr 24(525), s. 6. 
ma na celu wywołanie nastroju, a nie budowanie formy, która jest zupełnie dwuwymiarowa $^{173}$.

Lato, Royal Academy of Art — Piccadilly, Londyn Letnia wystawa - „Summer Exhibition”, na której wśród ponad 1500 eksponatów pokazano prace Polaków. Z recenzji Alicji Drwęskiej:

[...] dobre obrazy są rzadkością — na szczęście jednak można je od czasu do czasu wyłowić i do nich też należą na ogół prace Polaków. Wymienię przede wszystkim Rynek w Antibes (sprzedany) i Dwie hiszpańskie dziewczyny Ruszkowskiego piękne w kolorze, mieniące się zielonkawą tonacją — w pejzażu skontrastowaną z plamami fioletu, $\mathrm{w}$ drugim obrazie zharmonizowaną $\mathrm{z}$ ciepłymi brązami. Forma jest jasno określona abstrakcyjna prawie - tak samo zresztą jak kolor — mimo to jednak związana jeszcze z naturą, tak, jak poetycka metafora odbiegająca od przedmiotu, a przecież podkreślająca jego istotę. [...] W tej samej sali zwrócił mą uwagę niewielki pejzażyk z białymi plamami śniegu, pełen wdzięku, delikatny w kolorze i namalowany z dużą kulturą nazwisko malarza: Augustus Pack, okazało się pseudonimem Polaka, Pacewicza. Wielki obraz, a raczej panneau, Marka Żuławskiego przenosi nas w atmosferę szarości nie tylko kolorytu lecz i codzienności życia — jakkolwiek tematem jest morze i kochankowie. Konstrukcja obrazu jest jasna, oszczędna, pełna rytmu, a szarości subtelne i wyszukane. Martwą naturę Wawrzkiewiczowej z wazonami i gruszkami, chyba widziałam już na jakiejś wystawie zeszłorocznej. [...] Natomiast pejzaż Pilawskiego, malowany swobodnie, interesujący zestawieniami głębokich błękitów i swą poetycką interpretacją rzeczywistości, wykazuje ogromny skok naprzód w rozwoju artysty, który dotychczas, można powiedzieć, nie wykraczał poza poprawną przeciętność. Ładne w kolorze i swej abstrakcyjnej kompozycji są Kwiaty (litografia) i Staw (akwatinta i sztych) Anny Dubieńskiej. Dwie ceramiki Stanisława Reychana mają wdzięk i prostotę autentycznych świątków, lecz widać w nich połączenie polskiej tradycji ludowej z wiedzą i kulturą plastyczną. Malutka rzeźba w drzewie (dąb) Witolda Kawalca ${ }^{174}$ jest nie tylko doskonałym osiągnięciem technicznym, lecz również ciekawym poszukiwaniem ekspresji abstrakcyjnej formy. [...] Projekty 2 witrażów Aleksandra Kleckiego do kościoła katolickiego w Uckfield (Sussex) nie wydają mi się zbyt interesujące — raczej sztywne w kompozycji ${ }^{175}$.

21 czerwca, Polska YMCA, 46/47 Kensington Gdns Square, Londyn Wycieczka artystyczna Polskiej YMCA do Hampton Court w celu zwiedzania pałacu i obejrzenia zbiorów. Przewodnikiem był Marian Bohusz-Szyszko ${ }^{176}$.

21 czerwca, „Wiadomości”, Londyn

W „Wiadomościach” ukazał się szkic — wspomnienie Rosy Bailly z pobytu na polskich Kresach w latach międzywojennych, pt. Klasztor $w$ Podkamieniu, z rysunkami Mariana Kratochwila: W kościele, Chtop, Wieś Podkamień, Droga i Kupno konia. We wspomnieniu jest mowa o autorze rysunków ${ }^{177}$.

${ }^{173}$ AE, MŻ, M. Żuławski, ,Round the Galleries No 46”, mps, k. 3.

${ }^{174}$ Por. też: M. Bohusz-Szyszko, Witold Kawalec, Tadeusz Wąs i dwaj Anglicy, TP $1964 \mathrm{nr}$ 34, s. 8 .

${ }^{175}$ A. Drwęska, Udziat plastyków polskich w „Summer Exhibition”, DPDŻ 20.07.1959, s. 3. O udziale A. Kleckiego - T. Zieliński, 7 rzeźb MADONNY. Rozmowa z rzeźbiarzem, TP 1959 nr 22, s. 12 .

${ }^{176}$ Odczyty i wystawy, TP $1959 \mathrm{nr} 21$, s. 15.

${ }^{177}$ R. Bailly, Klasztor w Podkamieniu, przeł. T. Terlecki, W 1959 nr 25(690), s. 2. 
22 czerwca - 2 lipca, Grabowski Gallery, 84 Sloane Avenue, Chelsea, Londyn Szósta z kolei wystawa w Galerii Grabowskiego. Zorganizowana w porozumieniu ze Związkiem Plastyków Polskich w Warszawie. Pokazano ok. 100 prac prawie 45 grafików z Polski ${ }^{178}$. Swoje prace zaprezentowali: St. Chludzińska, Mieczysław Majewski, Ludwik Maciąg, Zdzisław Adamski, Wanda Zdun-Zalewska, Ryszard Lech, Jadwiga Harbik-Wiśniewska, Kazimierz Podsiadecki, Jan Kucharski, Stefan Damski, Eugeniusz Stec, Stefan Rassalski, Danuta Kreon, Bronisław Kopczyński, Jerzy Burbo, Barbara Boratynowa, Aleksander Sołtan, Jadwiga Cybulska, Magdalena Gomulicka, Tadeusz Balcerzak, Bogumiła Rapelska, M. Hiszpańska-Neumann, Jadwiga Okońska, Krystyna Bieniek, Maria Liliszowska, Juchni Koroska, Bogusław Brandt, Jerzy Miller, Jan Kober, Hanna Jung, Halina Makorska, Wanda Ficowska, Janina Kondracka, Stefan Łukaszewski, Hanna Kohlmann, E. Nożka Paprocka, Waldemar Zaczek, A. Włodarz, Ż. Mróz-Pełczyńska, Bronisław Tomecki, Leon Śliwiński, Steller, Barbara Wesołowska, T. Tuszewski, K. Wasilewska-Burzyńska, K. Niedzielski, Fronk, W. Gackowska-Woźniak, J. Kulesza, H. Szczypińska, B. Łada, M. Puchalski, B. Maziarska-Wołonko, Wąsowicz Dar, S. Łuckiewicz, Mikołaj Sasykin, E. Skoczynoska-Sobocińska, M. Rajewski, D. Grzywaczewska-Siekierska, T. Żaczek ${ }^{179}$. Część prac można było obejrzeć w teczkach wyłożonych w sali Galerii. W „Obliczu Tygodnia” ukazała się szczegółowa ocena poszczególnych prac z wystawy ${ }^{180}$ oraz reprodukcje kilku grafik ${ }^{181}$. W entuzjastycznej recenzji w „Gazecie Niedzielnej”:

Spośród wielkiego wyboru drzeworytów, linorytów i litografii tematycznie pierwsze miejsce zajmuje Warszawa w interpretacji B. Brandta, J. Kobera, J. Millera, H. Ming, D. Kern, H. Makarskiej i innych ${ }^{182}$.

23 czerwca - 11 lipca, Drian Gallery, 7 Porchester Place, Marble Arch, Londyn Wystawa malarstwa Manuela Benaima i Johna Ratcliffa ${ }^{183}$.

Lato, Royal Society of British Artists Galleries, 66 Suffolk St., Londyn Summer Exhibition of the London Group z udziałem m.in. Haliny Korn:

Halina Korn, której rzeźba zachwyca formą, wystawiła obraz Łaźnia Turecka, przedstawiający dziewięć aktów kobiecych potraktowanych z humorem, a wręcz niełaskawie ${ }^{184}$.

27 czerwca, „Tydzień Polski”, Londyn

„Tydzień Polski” wydrukował rozmowę Zygmunta Kona z rzeźbiarzem Tadeuszem Zielińskim, z okazji ukończenia przez niego rzeźby w drewnie lipowym Matki Boskiej Apokaliptycznej dla kościoła w Uckfield koło Eastbourne w Sussex.

Oto, co artysta opowiada o swojej pracy. - Kościół z Uckfield jest nowy i nowoczesny. [...] Zrobiłem dla tego kościoła Rękę Boska z krzyżem i symbolami, długości

${ }^{178}$ M. C., Wystawa grafików z nad Wisty, OB-S 1959 nr 25, s. 4.

179 A. Drwęska, Wystawa Grafików Polskich, DPDŻ 29.06.1959, s. 3; D. Step, Leon Śliwiński, Merkuriusz Polski - Życie Akademickie 1960 nr 7-8(122-123), s. 23-24.

${ }^{180}$ K. Kostynowicz, Ocena prac grafików krajowych. (Z. Galerii Grabowskiego), OT 1959 nr 40(90), s. 5.

${ }^{181}$ (k.), Graficy krajowi u Grabowskiego, OT. Dodatek Ilustrowany 1959 nr 37, s. b-c.

${ }^{182}$ Nowa sensacja w Galerii Grabowskiego, Gazeta Niedzielna 1959 nr 15(526), s. 5.

${ }^{183}$ AE, HN, Drian, Manuel Benaim [folder wystawy], [London 1959], Ratcliff: paintings [zaproszenie na wystawę].

${ }^{184}$ G. S. Whitter, London Commentary, The Studio 1959 (lipiec), s. 28-31 [tłum. — red.]. 
3 i pół stopy. W drzewie lipowym. Jest malowana i złocona, wisi w prezbiterium nad głównym ołtarzem.

- A gdzie jest Madonna?

- Na prawej ścianie głównej nawy. Cała ściana jest z drzewa, z otworem i sztucznym światłem niebieskim dla Madonny. Po bokach są 2 okna z witrażami, projektowane przez architekta Aleksandra Kleckiego. Witraże są bardzo nowoczesne. Ze szkieł różnych kolorów wycięto poszczególne figury i obciągnięto ołowiem. Linia ołowiu tworzy rysunek. Szkło nie było malowane. [...] Ks. proboszcz Plummer zamówił u nas jeszcze 12 podobnych witraży dla 12 pozostałych okien. [...]

- Ile Pan ogótem zrobit Madonn?

- Siedem poczynając od Kozielskiej, w r. 1941. Drugą z kolei wykonałem dla kaplicy obozowej w Palestynie, w r. 1943, w drzewie orzechowym. Trzecią, wielkości naturalnej, wyrzeźbiłem w drzewie brzoskowym [wiązowym] (Elm Wood) dla klasztoru Urszulanek Our Lady of Light w Upton Park w r. 1948. - W r. 1957 zrobiłem dwie Madonny, dla Fatimy i dla kościoła Our Lady of Lourdes, w Kent. Ta ostatnia jest z drzewa lipowego, malowana, ma przeszło 5 stóp. Stoi w grocie z kamienia w ogrodzie kościoła w Kent. Szóstą zrobiłem w r. 1958 dla kaplicy kościoła katolickiego w Newcastle-on-Tyne. Jest to Matka Boska Różańcowa z drzewa jaworowego. [...]

- Czy Pan rzeźbi tylko w drzewie?

- Pracuję także w kamieniu. Z pomocą mistrza kamieniarskiego Hermana Hauge, Norwega. Zrobiłem w Londynie 8 nagrobków, w granicie czarnym i szarym. Trzy są na cmentarzu Brompton: gen. Nikodema Sulika, Tomasza Arciszewskiego i St. Gorzeńskiego-Ostroroga. Dalsze trzy są na Streatham Park Cemetery: Jana Aleksego Wilczyńskiego, Małgorzaty Godowskiej i ostatni - Aliny Fall. Na Fulham Cemetery, w North Sheen, jest pomnik Konstantego Misiaka, a na Acton — prof. Tadeusza Brzeskiego.

- Nad czym Pan teraz pracuje?

— Robię popiersie Chopina, z rękami i klawiaturą, w drzewie gruszkowym. Uprzednio zrobiłem w tym samym drzewie głowę Chopina. [...]

- Uprawia Pan też malarstwo?

- Oczywiście. Zrobiłem ostatnio portret Miss Daphne Warrington, bardzo pięknej rudej Angielki. Pokażę go na swej najbliższej wystawie w Galerii Grabowskiego.

Wywiad ilustrowany jest fotografią rzeźbiarza, witrażem A. Kleckiego Our Lady of Good Councel oraz rzeźbą Matka Boska Apokaliptyczna ${ }^{185}$.

28 czerwca, Polska YMCA, 46/47 Kensington Gdns Square, Londyn Wycieczka artystyczna Polskiej YMCA do Victoria \& Albert Museum z prelekcją Mariana Bohusza-Szyszko. Wycieczka ,ze szczególnym uwzględnieniem przybyłych z Polski",186.

1 lipca, Polish Programmes BBC, Londyn

Audycja Marka Żuławskiego poświęcona wystawom Ivona Hitchensa, Jeana Fautriera, Franciszki Themerson, Barnabé. „Round the Galleries” nr $46^{187}$.

4 lipca - 5 sierpnia, Grabowski Gallery, 84 Sloane Avenue, Chelsea, Londyn Tzw. Summer Collection - Wystawa Letnia. Prezentowała prace 34 plastyków: Anglików, Francuzów, Włochów, Hiszpanów, Amerykanów, Węgrów i Polaków, wśród nich: Halina Sukiennicka, W. Wereszczyńska, Marek Łączyński, Tadeusz Znicz-Muszyński. W „Obliczu Tygodnia” krytyczna recenzja: „Dziwne, że cała wystawa w obecnym

\footnotetext{
${ }^{185}$ T. Zieliński, 7 rzeźb MADONNY. Rozmowa z rzeźbiarzem, TP 1959 nr 22, s. 12.

186 Odczyty i wystawy, TP 1959 nr 22, s. 15.

${ }^{187}$ AE, MŻ, M. Żuławski, „Round the Galleries No 46”, mps, 4 k.
} 
salonie Grabowskiego, pomimo drakońskiej selekcji zastosowanej przez jury przy 75 proc. odrzuconych prac jest zaledwie dobra" ${ }^{188}$ oraz reprodukcje prac Wereszczyńskiej Martwa natura, Sukiennickiej Martwa natura, Znicza (bez tytułu) ${ }^{189}$. Równocześnie wystawa obrazów olejnych, akwareli i tkanin Lea (Lea Aspling) ${ }^{190}$.

5 lipca, Polish Programmes BBC, Londyn

Audycja Marka Żuławskiego pt. „Francis Bacon, American Painters, Michael Ayrton, Adolf Gottlieb, Ben Nicholson”. ,Round the Galleries” $\mathrm{nr} 47^{191}$.

11 lipca - 1 sierpnia, Midland Group Gallery, Nottingham Wystawa malarstwa Marka Żuławskiego przeniesiona z Newcastle, a wcześniej z Zwemmer Gallery — „Marek Zulawski. Exhibition of Paintings and Litographs”192.

14 lipca, Paryż

Zmarł w Paryżu Franciszek Ksawery Black, ur. 3 XII 1881 w Warszawie, malarz w latach powojennych pracujący w Wielkiej Brytanii, przed I wojną światową był jednym $\mathrm{z}$ autorów pomnika grunwaldzkiego w Krakowie i przyjacielem I. Paderewskiego. Zostawił dwie córki: pianistkę Mayę Black i Jeannette Barbara ${ }^{193}$.

14 lipca - 1 sierpnia, Drian Gallery, 7 Porchester Place, Marble Arch, Londyn Wystawa „Three Brazilian Artists”: Joao Luis Chaves — Frans Krajcberg — Artur Luis Piza $^{194}$.

Lipiec, Zrzeszenie Plastyków Polskich, Polska YMCA, Londyn

Kuba Kostynowicz wygłosił odczyt pt. „Światła i cienie sztuki i kultury plastycznej”. Fragmenty drukowane były w „Obliczu Tygodnia”"

19 lipca, Polska YMCA, 46/47 Kensington Gdns Square, Londyn Wycieczka artystyczna Polskiej YMCA do British Museum z prelekcją Mariana Bohusza-Szyszko o nowościach w British Museum ${ }^{196}$.

\footnotetext{
${ }^{188}$ K. Kostynowicz, Wystawa Letnia w Galerii Grabowskiego, OT 1959 nr 41(91), s. 7.

${ }^{189}$ Wystawa Letnia w Galerii Grabowskiego, OT. Dodatek Ilustrowany 1959 nr 41, s. d.

${ }^{190}$ J. W. Sienkiewicz, Polskie galerie sztuki w Londynie, s. 281.

${ }^{191}$ AE, MŻ, M. Żuławski, „Francis Bacon, American Painters, Michael Ayrton, Adolf Gottlieb, Ben Nicholson", mps, 4 k.

${ }^{192}$ Marek Zulawski. Exhibition of Paintings and Litograps [katalog wystawy], 11 VII 1 VIII, Nottingham: Midland Group Gallery, 1959.

${ }^{193}$ H. Bartnicka-Górska, J. Szczepińska-Tramer, W poszukiwaniu światta, kształtu i barw. Artyści polscy wystawiający $w$ Salonach paryskich w latach 1884-1960, Warszawa 2005, s. 292; Rocznik Polonii Zagranicznej na rok 1948, Londyn 1947, s. 219; Nekrolog, DPDŻ 29.07.1959, s. 4; Biblioteka Polska w Londynie, Kartoteka B. Jeżewskiego, „Wspomnienie Maryi Kasterskiej" [b.d.].

${ }_{194}$ AE, HN, Drian, Three Brazilian Artists: Chaves, Krajcberg, Piza [folder wystawy], [London 1959]; M. Wykes-Joyce, Drian Galleries, s. 13; J. W. Sienkiewicz, Polskie galerie sztuki w Londynie, s. 273; Notatki, Gazeta Niedzielna 1959 nr 35(536), s. 6 - informacja o polskości Krajcberga.

${ }^{195}$ [K. Kostynowicz], Światta i cienie sztuki i kultury plastycznej (wyjątki z referatu Kuby Kostynowicza, wygłoszonego w Zwiąku Plastyków Polskich w Londynie), OT 1959 nr 41(91), s. 4.

${ }^{196}$ Odczyty i wystawy, TP $1959 \mathrm{nr} 25(171)$, s. 15.
} 
Lato, kościół St. Mary, Swansea, Walia

W jednej z niszy kościoła stanęła rzeźba św. Edeyerna, wykonana na zamówienie przez polskiego rzeźbiarza Kostkę Wojnarowskiego ${ }^{197}$.

26 lipca, Polska YMCA, 46/47 Kensington Gdns Square, Londyn Wycieczka artystyczna do St. Albans, zorganizowana przez Polską YMCA i poprowadzona przez Mariana Bohusza-Szyszko ${ }^{198}$.

Sierpień, Tate Gallery, Londyn

Wystawa sztuki romantycznej pt. „The Romantic Mouvement” zorganizowana staraniem Rady Europy ze Strasburga oraz brytyjskiej Rady Sztuki. Ogółem zgromadzono na wystawie blisko 1000 obrazów, rzeźb, rysunków i prac graficznych. Wśród obrazów pokazano dwa małe obrazy Piotra Michałowskiego z Muzeum Narodowego z Warszawy: Samosierra i Kawaleria Napoleońska ${ }^{199}$.

1-9 sierpnia, Instytut Historyczny im. gen. Sikorskiego, 20 Princes Gate, Londyn Wystawa obrazująca pracę i dorobek Brygadowe Koło Młodych „Pogoń” za okres dziesięciu lat działalności. Na wystawie pokazano m.in. dokumentację fotograficzną i literacką dotyczącą Wilna ${ }^{200}$.

2 sierpnia, Osiedle Polskie w Penrhos, k. Pwllheli, hr. Caenarvon, Walia Otwarcie wystawy malarskiej Ireny Valdi-Gołębiowskiej (Tesco).

Źródłem natchnienia malarki jest przyroda widziana w swej pierwotnej prawdzie, a nie przez pryzmat współczesnych modnych kierunków ${ }^{201}$.

4-21 sierpnia[?], Drian Gallery, 7 Porchester Place, Marble Arch, Londyn Wystawa malarstwa Douglasa Portwaya ${ }^{202}$.

9 sierpnia, Polska YMCA, 46/47 Kensington Gdns Square, Londyn Wycieczka artystyczna zorganizowana przez Polską YMCA do Wallace Collection z odczytem Mariana Bohusza-Szyszko pt. „Odrębność Szkoły Brytyjskiej”,203.

12-29 sierpnia, Grabowski Gallery, 84 Sloane Avenue, Chelsea, Londyn Wystawa 40 płócien 37 malarzy angielskich, studentów sześciu szkół artystycznych, pt. „Tomorrow's Artists Exhibition"204. Wśród pokazywanych prac dzieła Toni Clarke, Gwena Evansa, J. G. Bevana, Jannet Harris i Johna Epsteina. Jury zebrane w galerii przyznało sześć nagród dla najzdolniejszych studentów, ufundowanych przez M. Grabowskiego.

${ }^{197}$ Rzeźbiarz wizjoner, DPDŻ 23.06.1959, s. 3.

${ }^{198}$ Odczyty i wystawy, TP 1959 nr 26, s. 15.

199 AE, MŻ, M. Żuławski, ,,The Romantic Mouvement, Ken Armitage”, mps, k. 3.

${ }^{200}$ Odczyty i wystawy, TP 1959 nr 26, s. 15; Z. Kon, Święto 10-lecia „Pogoni”, DPDŻ 12.08.1959, s. 3 .

${ }^{201}$ T. W. S., Malarka z Penrhos, DPDŻ 13.08.1959, s. 3.

${ }^{202}$ M. Wykes-Joyce, Drian Galleries, s. 18.

${ }^{203}$ Odczyty i wystawy, TP $1959 \mathrm{nr} 28$, s. 15.

${ }^{204}$ G. S. Whittet, London commentary, The Studio 1959 (listopad), s. 125. 
Reprodukcje nagrodzonych prac zamieściło „Oblicze Tygodnia”205 oraz „Tydzień Polski”, który zanotował uwagi prasy brytyjskiej. W „Daily Telegraph” napisano:

Zapoczątkowanie nowego rodzaju mecenatu nad sztuką, który powinien był być domeną brytyjskiego przemysłu, przypadło w udziale polskiemu emigrantowi, aptekarzowi z Londynu ${ }^{206}$.

Równocześnie z wystawą studentów Galeria pokazała siedem pejzaży wschodnio-afrykańskiej dżungli M. Czyżniewicza z Kenii. Czyżniewicz — członek „East Africa Art and Craft Society" wielokrotnie wystawiał w Nairobi ${ }^{207}$.

13 sierpnia, Royal College of Art, 13 Kensington Gate, Londyn Wystawa obrazów Astrid Balińskiej-Jundziłł i jej dwóch kolegów-malarzy. Wszyscy absolwenci Royal College of Art.

Balińska idzie ciągle w tym samym kierunku: coraz bardziej swobodnej interpretacji natury i właściwie jej obrazy są prawie abstrakcyjne. Transpozycja rzeczywistości jest już bardzo daleka od realnego przedmiotu, lecz, jakkolwiek luźne, pewne związki istnieją i już one właśnie pobudzają oraz skierowują wyobraźnię widza w odpowiednim kierunku, zmuszając go niejako do odtworzenia atmosfery i zrozumienia samego procesu twórczego przekształcenia świata rzeczywistego w świat rzeczywistości plastycznej, której wymową są barwy, formy, oraz materia malarska. [...] Jej konstrukcja jest na ogół jasna, materia malarska sensualna i bogata - lecz mam pewne zastrzeżenia co do kolorytu. Jej wcześniejsze płótno zwróciło uwagę barwą głęboką i szlachetną, obecne jej prace są mniej dźwięczne, tony są bardziej złamane, lecz mniej wyszukane, brak często mocniejszego kontrastu. Duże plamy mglistej bieli nie zawsze są dobrze zbalansowane i czasami robią wrażenie dziury niezamalowanego płótna ${ }^{208}$.

16 sierpnia, Polska YMCA, 46/47 Kensington Gdns Square, Londyn Wycieczka artystyczna Polaków do Greenwich, połączona ze zwiedzaniem pałacu i oglądaniem zbiorów, zorganizowana przez Polską YMCA i poprowadzona przez Mariana Bohusza-Szyszko ${ }^{209}$.

19 sierpnia, Londyn

Zmarł wybitny brytyjski rzeźbiarz i malarz Jacob Epstein. Urodził się w 1880 roku w Nowym Jorku w rodzinie polskich Żydów, którzy wyemigrowali w okresie pogromów z Rosji carskiej. Epstein jest autorem m.in. pomnika Oskara Wilde'a na paryskim cmentarzu (1912), rzeźby Josepha Conrada (1924). Pod koniec XIX wieku wyjechał z Nowego Jorku i osiadł w Paryżu, wkrótce jednak przeniósł się do Londynu i pozostał w nim aż do śmierci. W recenzji autobiografii rzeźbiarza, Mieczysław Grydzewski zanotował wspomnienia Epsteina, który miał napisać, że „ghetto nowojorskie przypominało podówczas żydowskie miasteczka w Polsce. Służące w domu Epsteinów były polskimi chłopkami, nie mówiły po angielsku, chodziły w chustkach na głowie i boso"210.

${ }^{205}$ K. Kostynowicz, Z Galerii Grabowskiego. „Tomorrow's artists”, OT. Dodatek Ilustrowany $1959 \mathrm{nr} 45$, s. d.

206 (St. G.), Laureaci Galerii Grabowskiego, TP 1959 nr 31, s. 15

207 Tamże.

${ }^{208}$ A. Drwęska, Wystawa pod znakiem trzynastki, DPDŻ 31.08.1959, s. 3.

${ }^{209}$ Odczyty i wystawy, TP $1959 \mathrm{nr} 29$, s. 15.

${ }^{210}$ [M. Grydzewski] Scrutator, Epstein rzeźbi Conrada, DPDŻ 3.09.1959, s. 2; (ad), Rzeźbiarz którego oceni potomność, TP 1959 nr 31, s. 5 — tam rzeźba J. Epsteina Joseph Conrad. 
Sierpień, Polish Programmes BBC, Londyn

Audycja Marka Żuławskiego pt. „The Romantic Mouvement, Kenneth Armitage”. „Round the Galleries” nr $48^{211}$.

23 sierpnia, Polska YMCA, 46/47 Kensington Gdns Square, Londyn Wycieczka artystyczna do Tate Gallery z przewodnikiem - Marianem BohuszemSzyszko ${ }^{212}$.

24 sierpnia - 12 września, Drian Gallery, 7 Porchester Place, Marble Arch, Londyn Wystawa malarstwa Belga Maurice'a Jadota, Niemca Klausa Jürgen-Fischera, Ruoffa i Niemkę Gudrun Krüger ${ }^{213}$.

30 sierpnia, Polska YMCA, 46/47 Kensington Gdns Square, Londyn Wycieczka artystyczna do Southwark Cathedral pod przewodnictwem Mariana Bohusza-Szyszko, zorganizowana przez Polską YMCA ${ }^{214}$.

Wrzesień, Klub Stowarzyszenia Polskich Kombatantów, Koło 334, Swindon Wystawa młodego malarza polskiego Józefa Burnasa, wychowanka Heatherley’s School of Art w Londynie i Studium Malarstwa Stalugowego Mariana Bohusza-Szyszko. Malarz pokazał dorobek dziesięciu lat twórczości.

Poza olejami ten młody plastyk polski pokazał szereg rysunków i skeczy czarnobiałych. Cechuje je dobrze opanowana technika. [...] Niestety, według pana Burnasa większość z publiczności swindońskiej zwiedzającej wystawę nie uległa czarowi piękna jakie na nich tryskało z płócien na ścianach Klubu $\mathrm{SPK}^{215}$.

Wrzesień, Londyn

Międzynarodowa wystawa „Hobby and Craft” z udziałem Polski. Pokazano na niej przeważnie eksponaty wykonane przez amatorów - hobbystów. W dziale polskim głównie zabawki i rzemiosło artystyczne.

Atrakcją stoiska ma być oryginalna Kurpianka, która na poczekaniu wycinać będzie ludowe wycinanki. Projektodawcą polskiego stoiska był grafik Jerzy Srokowski ${ }^{216}$.

1 września - 4 października ${ }^{217}$, Grabowski Gallery, 84 Sloane Avenue, Chelsea, Londyn Wystawa grafiki polskiej z kraju — „Polish Graphic Art”. Wzięło w niej udział kilkunastu (różne źródła podają 14 lub 16) absolwentów krakowskiej, wrocławskiej, warszawskiej i katowickiej ASP. Pokazano ponad sto prac, z przewagą drzeworytów. W tym prace: Haliny Chrostowskiej, Tadeusza Dominika, Marii Hiszpańskiej-Neuman, Mariana Maliny, Stefana Damskiego, Stanisława Dawskiego, Hanny Dąbkowskiej,

${ }^{211}$ AE, MŻ, M. Żuławski, ,The Romantic Mouvement, Ken Armitage”, mps, 5 k.

${ }^{212}$ Odczyty i wystawy, TP 1959 nr 30, s. 15.

${ }^{213}$ AE, HN, Drian, Maurice Jadot [folder wystawy], [London 1959]; Klaus Jürgen-Fischer [folder wystawy], [London 1959]; Ruoff [folder wystawy], [London 1959]; M. Wykes-Joyce, Drian Galleries, s. 24-27; J. W. Sienkiewicz, Polskie galerie sztuki w Londynie, s. 273.

${ }^{214}$ Odczyty i wystawy, TP $1959 \mathrm{nr} 31$, s. 15.

215 [E. Wojtczak] Lucyfer, Wystawa Józefa Burnasa, DPDŻ 9.09.1959, s. 3.

${ }^{216}$ ESTEB, Rozmaitości (sztuka i życie), DPDŻ 27.08.1959, s. 3.

217 Ogłoszenia informują, że wystawa miała trwać do 3 października, ale w końcu września ukazała się w „Dzienniku Polskim i Dzienniku Żołnierza” informacja, że zamknięcie wystawy nastąpi 4 października; por.: DPDŻ 30.09.1959, s. 3. 
Tadeusza Łapińskiego, Józefa Pakulskiego, Jerzego Panka, Edmunda Piotrowicza, Andrzeja Rudzińskiego, Ewy Śliwińskiej, Mieczysława Weismana, Mieczysława Jurgielewicza, Stefana Suberlaka ${ }^{218}$. Z recenzji Mariana Bohusza-Szyszko:

Graficy tutaj reprezentowani należą wiekiem do pokolenia w pełni rozwoju twórczego. Najmłodsi są urodzeni w roku 1928, a więc rozwijali się w okresie wojny i bezpośrednio po niej, najstarsi (Jurgielewicz, Pakulski, Dawski) są mniej więcej moimi rówieśnikami. Co do tych ostatnich warto zaznaczyć, że charakterem swej twórczości należą do nowej wizji ${ }^{219}$.

6 września, Polska YMCA, 46/47 Kensington Gdns Square, Londyn Wycieczka artystyczna Polskiej YMCA do British Museum z prelekcją Mariana Bohusza-Szyszko na temat „Nowych rysunków w British Museum”,220.

6-27 września, Dom Parafialny, 6 Mount Ave, Ealing, Londyn Wystawa gwaszów Heleny Eborowicz-Zaleskiej ${ }^{221}$. Otwarcia wystawy dokonał ks. T. Urbański. Dochód z wystawy (sprzedaż części prac i loteria) przeznaczony został na odbudowę kościoła katolickiego na Ealingu. H. Eborowicz, absolwentka petersburskiej Akademii Sztuk Pięknych (1913), znalazła się na początku wojny w Szkocji, gdzie wystawiła swoje obrazy dwukrotnie: w National Gallery i na wystawie British Council, która krążyła po Szkocji. Jej obraz przedstawiający św. Andrzeja Bobolę znajduje się w kościele katolickim w Kirkcaldy w Szkocji — dar wojska polskiego. Była też autorką trzech ołtarzy polowych. Tematyka prac H. Eborowicz to martwa natura, kwiaty, pejzaże i przede wszystkim portrety. Jeden z obrazów kupił gen. Józef Haller ${ }^{222}$.

12 września, ,Tydzień Polski”, Londyn

„Tydzień Polski” wydrukował rozmowę Zygmunta Kona z Feliksem Fabianem, ,portrecistą pięknych kobiet w Londynie", który dostał zamówienie na namalowanie portretu olejnego księcia Bedford.

Książę widział uprzednio serię Fabiana Porgy and Bess i jego 2 portrety p. Irmy Kowalskiej [...]

- Dtugo trwat seans?

- Półtorej godziny. Do portretu potrzeba mi 3 takich seansów. Książę opowiadał w czasie pozowania o swych wakacjach we Francji i Włoszech. Po seansie, gdy zdjął togę i odpoczywał, zrobiłem od niechcenia w kwadrans jego portret akwarelowy. Władysław Bednarski [fotograf z Londynu], w czasie pozowania, zrobił kilka zdjęć.

Rozmowa została dopełniona fotografią malarza szkicującego portret księcia Bedford ${ }^{223}$.

${ }^{218}$ M. Łączyński, Wystawa grafiki krajowej, DPDŻ 29.09.1959, s. 3. Ogłoszenie, OT 1959 $\mathrm{nr}$ 46(96), s. 4; Kel, Z Galerii Grabowskiego. Grafika polska, OT. Dodatek Ilustrowany $1959 \mathrm{nr}$ 47, s. d; J. C., Grafika z Polski w Galerii Grabowskiego, Gazeta Niedzielna 1959 nr 36(537), s. 6; Gazeta Niedzielna 1959 nr 38(539), s. 11.

${ }^{219}$ M. Bohusz-Szyszko, Grafika polska w Galerii Grabowskiego, TP 1959 nr 32, s. 11 tam dwie reprodukcje: M. Jurgielewicz Ta karczma Rzym się nazywa (1953), T. Dominik Macierzyństwo (1955).

${ }^{220}$ Odczyty i wystawy, TP 1959 nr 32, s. 15.

${ }^{221}$ Odczyty i wystawy, TP $1959 \mathrm{nr} 31$, s. 15.

${ }^{222}$ Lucy, Wystawa malarska na Ealingu. Helena Eborowicz-Zaleska, DPDŻ 22.09.1959, s. 3.

${ }^{223}$ F. Fabian, Polski malarz maluje portret księcia Bedford, rozmawiał Zygmunt Kon, TP 1959 nr 37, s. 11 . 
13 września, Polska YMCA, 46/47 Kensington Gdns Square, Londyn Wycieczka artystyczna organizowana przez Polską YMCA i zwiedzanie Wellington Collection z przewodnikiem, którym był Marian Bohusz-Szyszko ${ }^{224}$.

15 września, Drian Gallery, 7 Porchester Place, Marble Arch, Londyn Wernisaż wystawy holenderskiego malarza H. Jochemsa (12 płócien) ${ }^{225}$.

Wrzesień, Royal Society of British Sculptors, Londyn Polska rzeźbiarka Maja Boelke z Allfarthing Lane, Wandsworth, otrzymała pierwszą nagrodę na dorocznym konkursie dla rzeźbiarzy, zorganizowanym przez Królewskie Stowarzyszenie Rzeźbiarzy Brytyjskich ${ }^{226}$.

Wrzesień, Polish Programmes BBC, Londyn

Audycja Marka Żuławskiego poświęcona twórczości rzeźbiarzy: Jakóba Epsteina i Ettore Colla. ,Round the Galleries” nr $49^{227}$.

20 września, Polska YMCA, 46/47 Kensington Gdns Square, Londyn Wycieczka artystyczna Polskiej YMCA do National Gallery z prelekcją Mariana Bohusza-Szyszko i oprowadzaniem po wystawie rysunków ${ }^{228}$.

Jesień, Woburn Abbey, Bick's, 45 mil od Londynu

Feliks Fabian, portrecista, dostał zamówienie namalowania portretu olejnego Johna Russella, trzynastego Duke of Bedford ${ }^{229}$.

27 września, Polska YMCA, 46/47 Kensington Gdns Square, Londyn Wycieczka artystyczna, zorganizowana przez Polską YMCA, do Victoria \& Albert Museum, w czasie której Marian Bohusz-Szyszko opowiadał o nowych nabytkach ${ }^{230}$.

4 października, Polska YMCA, 46/47 Kensington Gdns Square, Londyn Wycieczka artystyczna zorganizowana przez Polską YMCA do British Museum z prelekcją Mariana Bohusza-Szyszko „Kultury południowo-amerykańskie”231.

Październik, Dom Kombatanta SPK, 11 Drumond Pl., Edynburg Marian Bohusz-Szyszko wystąpił na spotkaniu zorganizowanym przez Koło SPK z odczytem „Malarstwo polskie”: „Odczyt zgromadził nieliczne, ale dobrane grono osób, które słuchało odczytu z wielkim zainteresowaniem",232.

Październik, Polish Programmes BBC, Londyn

${ }^{224}$ Odczyty i wystawy, TP 1959 nr 33, s. 15.

${ }^{225}$ J. Ch., Z Drian Gallery, Gazeta Niedzielna 1959 nr 39(540), s. 6.

${ }^{226}$ Sukces polskiej rzeźbiarki, DPDŻ 14.09.1959, s. 1.

${ }^{227}$ AE, MŻ, M. Żuławski, ,,Round the Galleries No 49”, mps, 5 k.

${ }^{228}$ Odczyty i wystawy, TP 1959 nr 34, s. 15; Notatki, Gazeta Niedzielna 1959 nr 39(540), s. 6.

${ }^{229}$ F. Fabian, Polski malarz maluje portret księcia Bedford, z... rozmawiał Zygmunt Kon, TP 1959 nr 37, s. 11.

${ }^{230}$ Odczyty i wystawy, TP $1959 \mathrm{nr} 35$, s. 15.
${ }^{231}$ Odczyty i wystawy, TP $1959 \mathrm{nr} 36, \mathrm{~s} .15$.
${ }^{232}$ (B), Z Edynburga, DPDŻ 9.10 .1959$, s. 3. 
Audycja Marka Żuławskiego poświęcona wystawom Kazimierza Malewicza, Pierre’a Sculagesa, Paula Feilera, Juliana Trevelyana i Jeana Tinguely. „Round the Galleries” $\operatorname{nr} 50^{233}$.

Październik, „Encounter”, Londyn

W październikowym zeszycie miesięcznika „Encounter” (nr 73) wydrukowana została wkładka z rysunkami Feliksa Topolskiego.

Październik[?], Galeria przy Bond St., Londyn

Wystawa 22 olejów Feliksa Fabiana z cyklu Pergy and Bess, zorganizowana przez Columbia Pictures przy okazji brytyjskiej premiery filmu o tym samym tytule ${ }^{234}$.

Październik, Domus Libertatis, Kopenhaga

Ekspozycja III Światowej Wystawy Fotografiki Polskiej na Obczyźnie, która wcześniej pokazywana była w Ognisku Polskiej YMCA ${ }^{235}$. Pokazano 148 powiększeńn ${ }^{236}$.

Październik - listopad, Stowarzyszenie Fotografików Polskich - Polska YMCA, 46/47 Kensington Gdns Square, Londyn

W drugą rocznicę istnienia Stowarzyszenia Fotografików Polskich ukazał się pierwszy zeszyt [za rok 1959] „Biuletynu SFP”. Czasopismo ukazywało się nieregularnie do lat 80. pod redakcją Alojzego M. Repuchy (później także B. T. Lesieckiego). Wydrukowano pięć obszernych numerów (niektóre nawet 50-stronicowe) w formie maszynopisu powielanego, do których dołaczano oryginalne fotografie najwybitniejszych polskich fotografików tworzących na obczyźnie. Numer 1 zawierał: W. Marynowicz Stowarzyszenie Fotografików Polskich i jego cele, S. Arvay Wystawa „emigracyjna”...?, E. Baziuk Moje zdjęcia wystawowe..., S. Arvay Wystawa z Wroctawia, A. S. Ksiązki przeglad, Z. S. Frank W Studio..., S. A. Wrażenia $z$ „Royal” $i$ „International”, B. T. Lesiecki Od kolebki..., M.A.R. Lata 1958-1959..., Wystawy. Klub Fotograficzny Polskiej YMCA, Londyn, Stowarzyszenie Fotografików Polskich. Polska YMCA - Londyn, Goście z Kraju bioracy udziat w wystawach w latach 1958-1959, Z kartoteki... Alfabetyczna lista osób zwiazanych z życiem - bytego Klubu Fotograficznego Polskiej YMCA (1950-1957) - Stowarzyszenia Fotografików Polskich — Londyn (1957-1959).

Oraz oryginalne fotografie: M. Wondraczek Koniki, E. Baziuk Dokad idziemy, Z. W. Frank W Studio. Z tekstu W. Marynowicza:

Parę lat temu zebrało się kilku ludzi dobrej woli, zwolenników fotografii i powstał Klub Fotograficzny Polskiej YMCA. Napłynęło dużo nowych zgłoszeń, wyłoniły się nowe potrzeby, zamiary i cele; ramy Klubu stały się ciasne. Klub przeobraził się w Stowarzyszenie Fotografików Polskich i jako taki istnieje dwa lata. [...] Celem Stowarzyszenia Fotografików Polskich jest zrzeszenie Polaków, którzy są poważnie zainteresowani fotografiką, dla poszerzenia technicznej wiedzy i artystycznego podejścia w tej dziedzinie — tak głosi pierwszy punkt naszego regulaminu. Zamiarem naszym jest zrzeszyć się

${ }^{233}$ AE, MŻ, M. Żuławski, „Round the Galleries No 50”, mps, 5 k.

234 (St. G.), Piękne Polki i opera murzyńska, TP 1959 nr 20, s. 14. Nie wiadomo, czy doszło do wystawy, w artykule jest jej zapowiedź ustami F. Fabiana. W artykule reprodukcja obrazu Fabiana.

${ }^{235}$ Biuletyn. Stowarzyszenie Fotografików Polskich — Polska YMCA, Londyn [1959] nr 1, s. 26.

${ }^{236}$ O. T. Z., Polscy fotograficy w Danii, DPDŻ 5.10.1959, s. 3. 
przez prelekcje, kursy, pogadanki, wystawy, dyskusje, krytyki, podpatrywanie metod Kolegów w dobrym tego słowa znaczeniu ${ }^{237}$.

Październik, Galeria kina „Everyman”, Hampstead, Londyn W malutkim hallu kina wystawiono 15 litografii Marka Żuławskiego.

Żuławski jest, niewątpliwie, pod wpływem Picassa — lecz pod tym względem bynajmniej nie stanowi wyjątku, a jego nieco kanciaste i wydłużone formy, zgeometryzowane i jednocześnie podkreślające [...]. Kompozycje Żuławskiego są figuralne, skomponowane jasno i przejrzyście. Najczęściej postacie umieszczone są na jednolitym tle oszczędny kolor tworzy pewną przestrzenność, tak samo jak i linia podkreślająca rytm, który jest w tych kompozycjach bardzo ważnym elementem ${ }^{238}$.

4 października, „Wiadomości”, Londyn

W tygodniku Mieczysława Grydzewskiego ukazał się szkic Stanisława Frenkla na temat sztuki pt. Malarstwo romantyczne $w$ Tate Gallery ${ }^{239}$. Tekst ten był pierwszym artykułem S. Frenkla na temat sztuki za mieszczonym w tym czasopiśmie. Z czasem Frenkiel będzie jednym z najczęściej drukowanych w „Wiadomościach” polskich krytyków sztuki.

4 października, Polska YMCA, 46/47 Kensington Gdns Square, Londyn Odczyt Stefana A. Arvaya nt. „Problemy fotografiki kolorowej”240.

7-24 października, New Vision Centre Gallery, 4 Seymour Place, Marble Arch, Londyn Wystawa malarstwa i rysunku — „Paintings and Drawings” - Halimy Nałęcz, w galerii, którą w 1956 roku założyła wspólnie z dwoma malarzami angielskimi: Denisem Bowenem i Frankiem Avray'em Wilsonem. Na wystawie malarka zaprezentowała siedemnaście prac olejnych, w większości dużych, oraz dwanaście rysunków. Tytuły prac inspirowane były muzyką, np.: Tropical Symphony, Overture after Stravinsky, Blue Symphony, For Milhaud - poezją, np.: Homage to Poetry, Lyrical Sonnet - lub wydarzeniami z czasów wojny: Compulsion, Combat of Stars, In the Air ${ }^{241}$. Z recenzji Alicji Drwęskiej:

Farba położona szpachlą długimi, grubymi pociągnięciami, układa się jakby w wachlarze barwistych, mieniących się piór, na tle jednolitego tonu, malowanego gładko, prawie przeźroczyście. Kolor jest przebogaty, radosny, sensualny. Ma światło i przestrzenność. Tłuste warstwy farby wibrują, falują, stwarzają rytm i jednocześnie podkreślają konstrukcję kompozycji - dynamiczną, przeważnie zcentralizowaną i mocno związaną. Te płótna, o nazwach poetyckich, są też poetycznymi impresjami przetłumaczonymi na język malarski, piękny i dźwięczny. [...] Żywość i świeżość kolorytu przywodzi asocjacje z polskim malarstwem ludowym, pierzastość form przypomina mi wycinanki łowickie ${ }^{242}$.

${ }^{237}$ W. Marynowicz, Stowarzyszenie Fotografików Polskich i jego cele, Biuletyn. Stowarzyszenie Fotografików Polskich — Polska YMCA, Londyn [1959] nr 1, s. 3-4.

${ }^{238}$ A. Drwęska, Litografia Marka Żuławskiego, DPDŻ 27.10.1959, s. 3.

${ }^{239}$ S. Frenkiel, Malarstwo romantyczne w Tate Gallery, W $1959 \mathrm{nr} 40(705)$, s. 5.

${ }^{240}$ Kronika S.F.P. 1959-1963, Biuletyn. Stowarzyszenie Fotografików Polskich - Polska YMCA, Londyn [1963] nr 2, s. 25.

${ }^{241}$ M. Wykes-Joyce, Drian Galleries, s. 85; (n), Polskie życie kulturalne. Rozpoczecie Roku Akademickiego, OB-S $1959 \mathrm{nr}$ 42, s. 3.

${ }^{242}$ A. Drwęska, Obrazy Halimy Natęcz, DPDŻ 12.10.1959, s. 3. 
Malarka pokazała 17 wielkich płócien olejnych i 12 rysunków. Wystawie towarzyszył $\operatorname{katalog}^{243}$. Z recenzji w „Gazecie Niedzielnej”:

[...] malarstwo Halimy Nałęcz to burza, bujność i zmysłowość koloru. Siedemnaście płócien zastanawia siłą wizji malarskiej i czystością rozwiązania technicznego ${ }^{244}$.

7-24 października, Drian Gallery, 7 Porchester Place, Marble Arch, Londyn Wystawa prac amerykańskiego malarza A. L. Alcopleya, specjalizującego się w obrazach długich i wąskich, na wzór drapaczy chmur, który nazwał swoje abstrakcyjne prace Skyscraper Paintings ${ }^{245}$.

9-22 października[?], Polska YMCA, 46/47 Kensington Gdns Square, Londyn Ogólnopolska Wystawa Fotografii Abstrakcyjnej z Polski, przygotowana przez Polskie Towarzystwo Fotograficzne z Wrocławia ${ }^{246}$. Organizatorem i pomysłodawcą ekspozycji w Londynie był B. T. Lesiecki. Wprowadzenie do wystawy wygłosił na wernisażu Stefan Arvay. Pokazano prace m.in.: Tadeusza Knausa, Stanisława Kozłowskiego, Eugeniusza Łowiagina, Kazimierza Sadowego, Józefa Sapy, Edwarda Witeckiego, Władysława Zaleskiego i Jerzego Wiklendta ${ }^{247}$.

9 października - 4 listopada, Grabowski Gallery, 84 Sloane Avenue, Chelsea, Londyn Wernisaż wystawy trzech plastyków. Obok drzeworytów Marka Łączyńskiego ${ }^{248}$ w Galerii pokazano gwasze młodego angielskiego malarza Roy'a Turner Durrant'a oraz akwarele Edmone Adès, Egipcjanki mieszkającej we Francji. Wystawa drzeworytów Łączyńskiego dopełniona została katalogiem. Z recenzji Alicji Drwęskiej:

Łączyński w swych odbitkach podkolorowanych bloków drewnianych na papierze wyczarował pełne uroku i poezji kompozycje. Abstrakcyjne, lecz jakże sugestywne. Malarskie, a jednocześnie o wyraźnym charakterze drzeworytu. Słoje drzewne, cięcia dłutem są fakturą malarską, którą Łączyński operuje z niezwykłym wyczuciem i subtelnością. Posługując się dwoma, lub najwyżej trzema blokami, osiąga piękne tonacje barwne, bogate, pełne delikatnych niuansów. [...] Techniką przypomina Łączyński nieco drzeworyty japońskie - lecz w swej wizji malarskiej, jest przede wszystkim sobą ${ }^{249}$.

Recenzent w „Gazecie Niedzielnej”:

Grafika Marka Łączyńskiego to impresje abstrakcyjne z dużym zapleczem kultury koloru o sporej dozie graficzno-dekoracyjnego odczucia — w najlepszym tego słowa znaczeniu.

${ }^{243}$ Z. Kon, Dwie wystawy Halimy Natęcz, DPDŻ 31.10.1959, s. 3; Halima Nalecz. Paintings and Drawings, 7th-24th October 1959 [katalog wystawy], London: New Vision Centre Gallery, 1959.

${ }^{244}$ J. Ch., Obrazy Halimy Natęcz, Gazeta Niedzielna 1959 nr 42(543), s. 6.

${ }^{245}$ Z. Kon, Dwie wystawy Halimy Natecz, DPDŻ 31.10.1959, s. 3.

${ }^{246}$ Odczyty i wystawy, DPDŻ 9.10.1959, s. 4; (n), Polskie życie kulturalne. Rozpoczęcie Roku Akademickiego, OB-S 1959 nr 42, s. 3.

${ }^{247}$ S. Arvay, Wystawa z Wrocławia, Biuletyn. Stowarzyszenie Fotografików Polskich — Polska YMCA, Londyn [1959] nr 1, s. 10-11; Biuletyn. Stowarzyszenie Fotografików Polskich Polska YMCA, Londyn [1959] nr 1, s. 26; LES, Fotografie abstrakcyjne, DPDŻ 19.10.1959, s. 3.

${ }^{248}$ J. W. Sienkiewicz, Polskie galerie sztuki w Londynie, s. 281.

${ }^{249}$ A. Drwęska, Drzeworyty Marka Łączyńskiego, DPDŻ 22.10.1959, s. 3; J. L. Englert, Marek Łączyński, DPDŻ 18.12.1959, s. 3; Ogłoszenie, OT 1959 nr 51(101), s. 8; Międzynarodowa wystawa w Galerii Grabowskiego, OT. Dodatek Ilustrowany 1959 nr 54, s. d. 
[...] bardzo ciekawy eksperyment zestawienia trójki plastyków, wywodzących się z odmiennej tradycji i wypowiadających się odmienną techniką w różnorodny sposób ${ }^{250}$.

Juliusz L. Englert, recenzując wystawę drzeworytów Łączyńskiego, odnotował także wystawy krajowe z 1959 roku. Napisał:

Słucham z zainteresowaniem, jak Łączyński mówi o swych drukach, które w pierwszych dniach poszły w świat, między ludzi. ,Jestem im już niepotrzebny — nadałem im tryb życia..." Brzmi to prawie jak egzaltacja ${ }^{251}$.

Z recenzji w „Orle Białym”:

Znawcy sztuki abstrakcyjnej znajdą zapewne w tych drzeworytach jakieś wpływy Dalekiego Wschodu, dochodzące do Europy przez Amerykę [...]. Dla zwykłego „kibica” grafika Łączyńskiego przemówi przede wszystkim oryginalnością niezwykłych, bardzo szlachetnych harmonii ${ }^{252}$.

10 października - 4 listopada, Grabowski Gallery, 84 Sloane Avenue, Chelsea, Londyn Wystawa nowych akwarel Edmone Ades ${ }^{253}$.

11 października, Polska YMCA, 46/47 Kensington Gdns Square, Londyn Wycieczka artystyczna Polskiej YMCA do Tate Gallery z prelekcją Mariana Bohusza-Szyszko „Nowości w Tate Gallery”,254.

25 października, Polska YMCA, 46/47 Kensington Gdns Square, Londyn Inauguracja Roku Akademickiego 1959/1960 Społeczności Akademickiej USB w Ognisku Polskiej YMCA, z udziałem Aleksandry Piłsudskiej i b. marszałka Senatu Bohdana Podoskiego oraz W. Wielhorskiego. Wykład inauguracyjny pt. „Problem postępu w sztuce” wygłosił Marian Bohusz-Szyszko, poprzedzony „,wspomnieniem osobistym sprzed 40 lat, gdy jako maturzysta żegnał się ze szkołą, której dyrektorem był prof. St. Kościałkowski” - rektor SA USB ${ }^{25}$. Inauguracja stała się okazją do wręczenia dyplomów ukończenia szkoły czworgu studentów Szkoły Malarstwa Sztalugowego Mariana Bohusza-Szyszko oraz zaprezentowania ich prac dyplomowych. Swoje obrazy pokazali: Eugenia Lenczycka, Cecil Epril, Henryk Janiszowski i Franciszek Wysłouch. Wystawę otworzył M. Bohusz-Szyszko, który wygłosił prelekcję „O nauczaniu w malarstwie, ${ }^{, 256}$.

27 października - 14 listopada, Drian Gallery, 7 Porchester Place, Marble Arch, Londyn Wystawa malarstwa - oleje, gwasze i kolaże - Ruth Francken, Czeszki mieszkającej w Londynie. Pokazano wyłącznie prace powstałe w 1958 roku $^{257}$.

Listopad, Royal Photographic Society, Londyn

\footnotetext{
${ }^{250}$ Międzynarodowa trójka w Galerii Grabowskiego, Gazeta Niedzielna 1959 nr 43(544), s. 6.

${ }^{251}$ J. L. Englert, Marek Łaczyński, DPDŻ 18.11.1959, s. 3.

${ }^{252}$ M. Cybulski, Drzeworyty Marka Łaczyńskiego, OB-S 1959 nr 42, s. 3.

${ }^{253}$ J. W. Sienkiewicz, Polskie galerie sztuki w Londynie, s. 281.

${ }^{254}$ Odczyty i wystawy, TP $1959 \mathrm{nr} 37$, s. 15.

255 (n), Polskie życie kulturalne. Rozpoczęcie Roku Akademickiego, OB-S 1959 nr 42, s. 3.

256 (m.b.), Spoteczność Akademicka USB, DPDŻ 26.10.1959, s. 3.

257 AE, HN, Drian, Francken [zaproszenie na wystawę].
} 
Wystawa Royal Photographic Society: ponad 100 prac najwybitniejszych fotografików z całego świata. Z Polaków: L. Kinasz, J. Lewiński, W. Marynowicz, P. Mystkowski ${ }^{258}$.

Listopad, The Ben Uri Gallery, The London Jewish Museum of Art, Londyn Pośmiertna wystawa rzeźby Sir Jakoba Epsteina, z udziałem wdowy ${ }^{259}$.

3-21 listopada, Drian Gallery, 7 Porchester Place, Marble Arch, Londyn Wystawa malarstwa Nye Pharra ${ }^{260}$.

Listopad, Hanover Gallery, Londyn Wystawa obrazów Stefana Knappa.

Plamy i kształty są miękkie, swobodne, niemożliwe do określenia. Gdzieś z wewnątrz przebija smutek, jest dramatyczne napięcie, a w liniach modelujących tkwi ukryta siła biologiczna i żywiołowa. Obrazy Knappa przemawiają ogólnoludzkim językiem sztuki chociażby dzięki swym czysto malarskim walorom artystycznym, tak różne bodźce artystyczne przetworzył w oryginalny swoisty styl, ale równocześnie ten sposób malowania stwarza, przy finezyjnej grze niespokojnie poruszających linii, obrazy bardzo dekoracyjne i pełne ekspresji, podkreślenia wyrazu formą i kolorem, który nie traci subtelnej przejrzystości nawet przy użyciu jaskrawych i silnych barw ${ }^{261}$.

8 listopada, Polska YMCA, 46/47 Kensington Gdns Square, Londyn Wycieczka artystyczna Polskiej YMCA do National Gallery z odczytem Mariana Bohusza-Szyszko pt. „Malarstwo hiszpańskie”262.

10 listopada - 5 grudnia, Grabowski Gallery, 84 Sloane Avenue, Chelsea, Londyn Wystawa prac Józefa Czapskiego z Paryża i Zygmunta Turkiewicza ${ }^{263}$. Czapski wystawił 33 płótna olejne oraz 58 akwarel i rysunków piórkiem i ołówkiem; Turkiewicz pokazał 27 olejów na drzewie i płótnie oraz wiele rysunków. Wernisaż wystawy przyciągnął około 150 osób, wśród nich: Edwarda Raczyńskiego, Mariana Kukiela, gen. Kazimierza Wiśniowskiego, Erikę Lubomirską, Auberona Herberta oraz malarzy ze Zrzeszenia Plastyków Polskich w Wielkiej Brytanii: Stanisława Frenkla, Zygmunta Kowalewskiego, Tadeusza Znicz-Muszyńskiego, Marka Żuławskiego i Halinę Korn.

\footnotetext{
${ }^{258}$ S. L., Polska fotografia u siebie i wśród obcych, Gazeta Niedzielna 1959 nr 44(545), s. 6.

${ }^{259}$ The Ben Uri Story form Art Society to Museum and the influence of Anglo-Jewish Artists on the Modern British Movement, London 2001, s. 69, 94.

${ }^{260}$ AE, HN Drian, Paintings by Nye Pharr [folder wystawy], [London 1959].

${ }^{261}$ D. Step, Czy obrazy Knappa szokuja tylko barwa, forma, wielkościa??, Merkuriusz Polski — Życie Akademickie - Młoda Sztuka, 1960 nr 1(116), s. 7; N. Wallis, Northern Lights, The Observer 29.11.1959.

${ }^{262}$ Odczyty i wystawy, DPDŻ 7.11.1959, s. 4

${ }^{263}$ M. Cybulski, Sztuka jest zawsze abstrakcyjna. (Rozmowa z Józefem Czapskim przy wieszaniu), OB-S $1959 \mathrm{nr}$ 46, s. 4-5 - tam reprodukcja obrazu Metro Pasteur; M. Cybulski, O przekazywaniu zachwytu i o szczęściu malarskim. (Rozmowa z Zygmuntem Turkiewiczem), OB-S 1959 nr 48, s. 4-5; (k), Czapski w Galerii Grabowskiego, DPDŻ 9.11.1959, s. 3 - tam rysunek z wystawy „Autoportret”; J. C., J. Czapski i Z. Turkiewicz w Galerii Grabowskiego, Horyzonty $1960 \mathrm{nr}$ 44, s. 68-70; F. Laws, Art for the adventurous, The Guardian 12.11.1959; Enigmatic Studies in White, The Times 13.11.1959.
} 
Wiele rysunków Czapskiego i Turkiewicza sprzedano pierwszego dnia. P. Halina Frankowska, gość z Kanady, zdefiniowała otwarcie wystawy: „Wernisaż, jak przed wojną w warszawskim IPS'ie",264.

Reprodukcje obrazów zamieściło „Oblicze Tygodnia”: J. Czapski W oknie, Rodzina w kawiarni, Pusty teatr, Z. Turkiewicz Picture inspired by block of flats, Picture inspired by timber in docks, Nude ${ }^{265}$ oraz „Wiadomości”: J. Czapski - Kobieta $w$ oknie wagonu, Marek Hłasko, Z. Turkiewicz - Monotypia, Niewidomy ${ }^{266}$. Z recenzji w „Gazecie Niedzielnej”:

Turkiewicz [...] jest przedstawicielem szkoły nowoczesnej. Spojrzenie ma wyłącznie wizualne (plastyczne), technikę czysto osobistą, mieszaną: olej i tempera na gipsowych podkładach, dającą efekt fresku o matowej i sugestywnej emanacji koloru. [...] Malarstwo Czapskiego [...] wywodzi się z tradycji szkoły francuskiej, a głównie z postimpresjonizmu. Mimo niewątpliwych zalet kolorystycznych i dbałości o poszczególne płótna, nie daje nam w pełni wrażenia jednolitości i zdecydowanej osobowości artysty $^{267}$.

Wystawa, co zaznaczyli recenzenci, była sukcesem finansowym. Sprzedano wiele prac obu artystów ${ }^{268}$. Z recenzji Marka Żuławskiego dla BBC:

[...] Czapski wypracował sobie własną formę ekspresjonistyczną. Jest to jak gdyby Bonnard w połączeniu z Soutinem. Krytyka angielska przyjęła bardzo życzliwie prace Czapskiego, zwracając uwagę na jego dojrzały kolor i dobry rysunek. Czapski maluje ludzi we wnętrzach lub martwe natury, upraszczając nieco formę i szukając wyrazu poprzez złamane tonacje kolorów, przeciwstawione czasem partiom o dużej intensywności. W malarstwie Czapskiego jednak na pierwszy plan wybija się jego humanizm i wielka kultura ogólna. [...] Wpływ Wschodu z jego dekoracyjnie pojętym kolorem, dotąd widać w malarstwie Turkiewicza. Obecnie Turkiewicz znalazł się na pograniczu abstrakcji, ale o ile jego wcześniejsze, bardziej realistyczne prace miały dużo atmosfery i dojrzałości, ostatnie wydają się trochę przypadkowe. Z rozrzuconych prostokątów światła i koloru, buduje on mozaikowe kompozycje, które przypominają czasem drapacze chmur z oświetlonymi oknami, narysowane przez dziecko. Ale ta naiwność ma dużo poezji, a kolor Turkiewicza dowodzi niewątpliwie malarskiego widzenia ${ }^{269}$.

Z recenzji w paryskiej „Kulturze”:

Turkiewicz biorący udział w tej wystawie podobny jest do Czapskiego jedynie chyba w tym, że też nie przeszedł przez kubizm. [...] Obecnie, szokuje kolegów wystawiając gwasze zdradzające, że Matisse był dla jego rozwoju osobistością ważną i obok tych prawie klasycznych prac wieszając oleje, określane, w braku lepszej nazwy, jako semiabstrakcyjne. $\mathrm{Z}$ jednej strony jest on przekonany, że $\mathrm{z}$ ostatnią wojną skończyła się pewna epoka bezpowrotnie, a wraz z nią formy, które ją wyrażały, a z drugiej jest mimo wszystko świadom ciągłości swego malarstwa. Objętość i przestrzeń jego dawnych obrazów, przestrzeń pocézannowska wprawdzie, w której geometryczna ścisłość perspek-

${ }^{264}$ (A.M.), Wernisaż w Galerii Grabowskiego, DPDŻ 16.11.1959, s. 3. Ogłoszenie, OT 1959 nr 58(108), s. 5 .

265 (k.), Czapski $i$ Turkiewicz w Galerii Grabowskiego, OT. Dodatek Ilustrowany 1959 nr 58, s. b-c.

${ }^{266}$ Kronika: Wystawa Czapskiego i Turkiewicza, W 1959 nr 46(711), s. 6.

${ }^{267}$ J. Ch., J. Czapski i Z. Turkiewicz, w Galerii Grabowskiego, Gazeta Niedzielna $1959 \mathrm{nr}$ 47(548), s. 6 .

${ }^{268}$ Notatki, Gazeta Niedzielna 1959 nr 49(550), s. 6.

${ }^{269}$ AE, MŻ, M. Żuławski, „Round the Galleries No 51”, mps, k. 3-4. 
tywy renesansowej przestała obowiązywać, lecz mimo to wyraźna jak w malowidłach pompejańskich, znikła z jego ostatnich obrazów. Są one obecnie dwuwymiarowe, to co było przedtem w głębi, obecnie pojawia się obok, na płaszczyźnie, jak nieoczekiwane skojarzenie. [...] Dzięki temu Turkiewicz może więcej mówić o ciągłości swego malarstwa niż o zmianie, która w nim zaszła. A zmiana ta jest radykalna, mimo że ten sam cel dążenia do jasnej, logicznej konstrukcji, przyświeca mu, przy zmienionych środkach, nadal. Malarz ten prawie nie wystawiający dotąd wcale i żyjący w izolacji większej, niż to jest dla artysty zdrowe, może pokazać w przyszłości jeszcze wiele, bo widoczne jest, że znajduje się bliżej początku aniżeli końca swego rozwoju ${ }^{270}$.

\section{Z bardzo późnej recenzji Stefanii Zahorskiej:}

Nie jest rzeczą sprawozdawcy plastycznego wskazywanie malarzom drogi lub krytykowanie obranego przez nich kierunku. W stosunku do Turkiewicza chcę tylko zaznaczyć że obecne jego eksperymenty robią wrażenie zbyt uproszczonych wobec możliwości jego talentu i dotychczasowego dorobku. Może wiodą do czegoś co się potem okaże pełne znaczenia: dziś wydają się etapem przejściowym, chwilami interesującym w prostocie i świeżości ujęcia, chwilami jednak zbytnio rozbitym na drobne części składowe ${ }^{271}$.

Ukazał się także artykuł wspomnieniowy W. A. Zbyszewskiego o J. Czapskim, w którym omówione zostały niektóre obrazy ${ }^{272}$. Na zakończenie wystawy Józef Czapski wygłosił wykład „Abstrakt: za i przeciw, czyli zemsta Matejki”273.

Listopad, Polish Programmes BBC, Londyn Audycja Marka Żuławskiego poświęcona wystawom w londyńskiej Leicester Gallery: Johna Pipera i Ben Shana, a także ekspozycjom Louisa Le Brocquy i rzeźby afrykańskiej oraz wystawie Józefa Czapskiego i Zygmunta Turkiewicza. „Round the Galleries” nr $51^{274}$.

15 listopada, Polska YMCA, 46/47 Kensington Gdns Square, Londyn Wycieczka artystyczna Polskiej YMCA do National Gallery z wykładem Mariana Bohusza-Szyszko „Szkoła Wenecka”275.

15 listopada, Polska YMCA, 46/47 Kensington Gdns Square, Londyn Otwarcie wystawy Władysława Wołkowskiego - prace w wiklinie, sznurze i drewnie. Otwarcia dokonał Marian Bohusz-Szyszko ${ }^{276}$. Pokazano 50 eksponatów. W recenzji znalazła się informacja, że wystawa ta po prezentacji w Polskiej YMCA zostanie zaprezentowana w firmie meblarskiej Heal w Londynie ${ }^{277}$.

Jesień, „Daily Telegraph”, Londyn Laureatem dorocznej nagrody „Daily Telegraph” został Zbigniew Raczek, papieroplastyk, dekorator, kierownik pracowni dekoracyjnej w domu towarowym na High Street Kensington Derry \& Toms ${ }^{278}$.

${ }^{270}$ S. Arvay, Wystawa Czapski-Turkiewicz, Kultura 1959 nr 1-2(147-148), s. 195-196.

${ }^{271}$ S. Zahorska, Wystawy, W 1959 nr 51/52(716/717), s. 25.

${ }^{272}$ W. A. Zbyszewski, Zjedzona martwa natura. O malarstwie Józefa Czapskiego, TP 1959 nr 41, s. 4.

${ }^{273}$ (A.M.), Zemsta Matejki, DPDŻ 10.12.1959, s. 3.

${ }^{274}$ AE, MŻ, M. Żuławski, ,„Round the Galleries No 51”, mps, 4 k.

275 Odczyty i wystawy, TP $1959 \mathrm{nr}$ 40, s. 7.

276 Tamże.

277 (k), Wyroby artystyczne z polskiej wikliny, DPDŻ 10.12.1959, s. 3.

${ }^{278}$ E. Wojtczak, Polskie pejzaże w południowym Londynie, DPDŻ 16.11.1959, s. 3. 
18 listopada - 5 grudnia, Drian Gallery, 7 Porchester Place, Marble Arch, Londyn Wystawa malarstwa Belga Josepha Lacasse'a, do której Halima Nałęcz wydała duży katalog ze wstępem Rogera Bordiera ${ }^{279}$.

22 listopada - 16 grudnia, Polska YMCA, 46/47 Kensington Gdns Square, Londyn II Doroczna (jesienna) Wystawa Stowarzyszenia Fotografików Polskich — Polska YMCA, z udziałem 21 fotografików, którzy wystawili 88 fotogramów czarno-białych oraz 53 przezrocza w kolorze ${ }^{280}$. Były to portrety, studia, pejzaże wiejskie i miejskie, martwe natury, kwiaty i kompozycje. Swoje prace pokazali: J. Barucki, E. Baziuk, Z. W. Frank, P. Klausner, T. Kupiec, J. S. Lewiński, B. T. Lesiecki, J. R. Nowak (pejzaże z Hiszpanii), W. Pohlman (pejzaże z Włoch), J. Schmidtke, L. S. Stanton-Święcicki (pejzaże z Polski), T. M. S. Sumorok, M. Wandraczek oraz S. Arvay, W. Marynowicz i L. Meller (m.in. profil W. Andersa). Przezrocza zaprezentowali: A. Helak, L. Kinasz, S. Kumoń i S. Kurzyna ${ }^{281}$.

Listopad, Camera-Club, Londyn Wystawa prac fotograficznych Władysława Marynowicza, wykładowcy zaawansowanej fotografii w Ealing Technical College. Inicjatorem wystawy był członek zarządu Camera-Club i sekretarz sekcji portretowej — Ludwik Meller. Pokazano portrety, martwe natury, krajobrazy, zwierzęta, kwiaty, akty kobiece, sport, impresjonistyczne kompozycje. „Wszystkie prace Marynowicza cechuje nieskazitelna technika i śmiałość wizji przy zaskakującej, nowatorskiej prostocie środków”. Camera-Club zaprosił W. Marynowicza również do wygłoszenia odczytu w klubie pt. „More about Lighting, Composition and Posting". Wcześniej Marynowicz mówił w Camera-Club o sztuce portretowej $^{282}$.

29 listopada, „Wiadomości”, Londyn

Ukazał się szkic Stanisława Frenkla Malarstwo Malewicza, będący recenzją wystawy w Whitechapel Gallery ${ }^{283}$.

29 listopada, Polska YMCA, 46/47 Kensington Gdns Square, Londyn Wycieczka artystyczna Polskiej YMCA do National Gallery z prelekcją Mariana Bohusza-Szyszko „,Szkoła Umbryjska"284.

29 listopada - 18 grudnia, South London Art Gallery, Londyn Wystawa „The Religious Theme” z udziałem Marka Żuławskiego ${ }^{285}$.

Zima, Camberwell College of Art, Londyn

${ }^{279}$ Lacasse. [Katalog], London: Drian Gallery, 1959; M. Wykes-Joyce, Drian Galleries, s. 17, 19; J. W. Sienkiewicz, Polskie galerie sztuki w Londynie, s. 273; Apollo 1959 nr 10, okł.

${ }^{280}$ Wystawy, imprezy, Biuletyn. Stowarzyszenie Fotografików Polskich — Polska YMCA, Londyn [1963] nr 2, s. 27.

${ }^{281}$ Wystawa fotografii, DPDŻ 14.12.1959, s. 8.

282 (g.), Wystawa fotografii Marynowicza, DPDŻ 23.11.1959, s. 3.

${ }^{283}$ S. Frenkiel, Malarstwo Malewicza, W 1959 nr 48(713), s. 5.

${ }^{284}$ Odczyty i wystawy, TP 1959 nr 42, s. 7.

${ }^{285}$ AE, MŻ, Wystawy 1951-1959, The Religious Theme [zaproszenie na wystawę]. 
Praca papieroplastyczna Okręt, wykonana w display studio domu towarowego Jones \& Higgins w Peckham na południu Londynu, przez Jerzego Nowiaka, została przejęta do stałej ekspozycji w zbiorach Camberwell College of $\mathrm{Art}^{286}$.

Listopad 1959 - styczeń 1960, Walker Art Gallery, Liverpool

Second John Moores Liverpool Exhibition z udziałem Zdzisława Ruszkowskiego ${ }^{287}$.

Grudzień, Polska YMCA, 46/47 Kensington Gdns Square, Londyn

Ósma doroczna wystawa Studium Malarstwa Sztalugowego Społeczności Akademickiej USB. Na wystawie pokazano prace uczniów Mariana Bohusza-Szyszko. Byli wśród nich Ukraińcy: Hala i Alek Baykow, oraz pięciu Brytyjczyków: Gillian Bradshaw-Smith, Sybil Keaptland, Marian Pickard, Vivienne Thornton i Alfred Craven, a także Polacy: Krystyna Berens, Karolina Borchardt, Tadeusz Dobrański, Stanisław Dubiel, Bogusław Gorgolewski, Irena Kaczmarek, Wanda Lekis, Bogusław Madey (muzyk z Kraju), Irena Paluch, Stefan Stachowicz, Andrzej Bohusz-Szyszko, Helena Śliwińska, Stanisława Witorzeniec, Alba Tavlor. Wernisaż otworzyła Halina Sukiennicka, która

mówiła o malarstwie i jego roli w życiu, o nurtach polskiej kultury i twórczości malarskiej w Kraju i na emigracji, o szkole malarstwa sztalugowego, która istnieje bez protokołu, regulaminu, funduszów, pomocy ani presji opinii publicznej i o jej potrzebie. Ilustrowała swe przemówienie cytatami z poematu Bronisława Przyłuskiego o malarstwie.

Wernisaż, na który przyszło przeszło 50 osób, został nagrany na taśmie dźwiękowej przez dyrektora YMCA B. T. Lesieckiego ${ }^{288}$. Z recenzji Stefanii Zahorskiej:

Ostatnia wystawa absolwentów Szkoły świadczy bardzo dobrze o metodzie nauczania, a co znaczy malowanie charakteru, nie wyglądu, i 'ekspresyjne przeinaczanie natury', stwierdziłam tak naocznie, że posłużę się tym jako przykładem. Na wystawie znajduje się portret własny jednego z kończących uczniów. Mr. Cecil Epril, Anglik, architekt, prezentujący się doskonale. Od chwili kiedy w sztuce europejskiej zjawiły się zindywidualizowane portrety, były one zawsze mniej lub więcej schlebiające. Najczęściej, np. w odrodzeniu a w szczególności $\mathrm{w}$ baroku, portret podnosił stanowisko portretowanego, zmieniał proporcje przez ubiór i gromadził efekty barwne dla podkreślenia wspaniałości, siły, władzy. Potem tematem schlebiającej idealizacji było podkreślenie wartości moralnych (malarstwo romantyczne), uduchowienie, dobroć. W impresjonizmie skala się odwróciła: brzydota, charakterystyczna i bierna, była częstym motywem artystów, człowiek był ujmowany przede wszystkim jako twór natury. Mr. Epril stojąc przed lustrem by namalować siebie dokonał przewartościowania - à rebours. Zobaczył siebie jako podstarzałego, trochę skurczonego już, zbiedzonego, nawet nieogolonego, bezradnego jegomościa. Powiedział o sobie: taki jestem naprawdę. Z kończących szkołę być może najwybitniejsza jest Eugenia Lenczycka; ekspresja łączy się u niej z dekoracyjnością układu, kolory są przytłumione i subtelne. Dobre są obrazy Henryka Janiszewskiego i Franciszka Wysłoucha. Z uczniów tegorocznego kursu na pierwszy plan wybija się Andrzej Bohusz-Szyszko, syn Mariana, pełen nieokiełznanego temperamentu, żywiołowej siły, niesamowitej w kolorze i w ekspresji. Jego dwa portrety własne są wstrząsające. Stefan Stachiewicz ima przyrodzoną delikatność w przygaszonych kompozycjach kolorystycznych. Bardzo interesująca jest Karolina Borchardtowa. Także Alfred Craven, Stanisława Witorzeniec, Helena Śliwińska. Nie ma zupełnie malarstwa

${ }^{286}$ E. Wojtczak, Polskie pejzaże w południowym Londynie, DPDŻ 16.11.1959, s. 3 - tam zdjęcie przedstawiające artystę oraz jego dzieło.

287 J. P. Hodin, Ruszkowski. Life and Work, London 1966, s. 11.

288 (A. M.), Malarstwo sztalugowe, DPDŻ 29.12.1959, s. 3. 
abstrakcyjnego. Uczniowie zaczynają od natury. To właśnie uważam za mądre podejście pedagogiczne. Hasłem jest „,kolor i ekspresja”,289.

5 grudnia, Grabowski Gallery, 84 Sloane Avenue, Chelsea, Londyn Na zakończenie wystawy w Galerii Grabowskiego Józef Czapski wygłosił wykład „Abstrakt: za i przeciw, czyli zemsta Matejki”. Zagajenie wygłosił Mateusz Grabowski oraz Stanisław Frenkiel z ramienia Zrzeszenia Polskich Plastyków, które było organizatorem wykładu ${ }^{290}$.

6 grudnia, Polska YMCA, 46/47 Kensington Gdns Square, Londyn

Wycieczka artystyczna Polskiej YMCA do Royal Academy of Arts, Piccadily w celu zwiedzenia wystawy zimowej. Oprowadzał Marian Bohusz-Szyszko ${ }^{291}$.

7-31 grudnia, Drian Gallery, 7 Porchester Place, Marble Arch, Londyn Wystawa „Recent Paintings” Włocha Ulrico Schettini ${ }^{292}$.

10 grudnia 1959 - 9 stycznia 1960, Grabowski Gallery, 84 Sloane Avenue, Chelsea, Londyn

Wystawa Group 49 (10th Anniversary) z okazji dziesiątej rocznicy powstania „Grupy 49"293. 42 prace pokazało 14 artystów: Janina Baranowska, Tadeusz Beutlich, Andrzej Bobrowski, Marian Bohusz-Szyszko, Mieczysław Chojko, Ryszard (Richard) Demel, Antoni Dobrowolski, Kazimierz Dźwig, Marian, Piotr Mleczko, Tadeusz ZniczMuszyński, Leon Piesowocki, Stefan Starzyński, Aleksander Werner. W prasie ukazały się reprodukcje kilku prac: A. Werner - Composition 3, T. Znicz-Muszyński - Summer lights, S. Starzyński - Fantasia, T. Beutlich — Man with bird ${ }^{294}$. Z okazji wystawy wydany został katalog pn. Group forty-nine. Tenth Anniversary, London 1959, w którym znalazły się krótkie biogramy 14 artystów oraz po dwie czarnobiałe reprodukcje ich prac ${ }^{295}$. Autorem zdjęć w katalogu był Adam Arway. Z recenzji Stefanii Zahorskiej:

Grupa 49 przeniosła się niemal cała w dziedzinę abstrakcji. Pamiętam, jej wystawę kilka lat temu: wiele kompozycji figuralnych, pejzaży, martwych natur — rzeczy, a był to już okres pełnego rozbujania abstrakcji. Dziś czas abstrakcji zdaje się mijać i oto z czternastu wystawiających artystów Grupy może tylko trzech (zresztą bardzo dobrych: Leon Piesowocki, Antoni Dobrowolski, Kazimierz Dźwig) wykazuje ślady obrazowania przedmiotów. Widocznie działa tu mus wewnętrzny, potrzeba wyeksploatowania nowych możliwości. Bo abstrakcja abstrakcji nierówna. Abstrakcja w ujęciu Grupy jest pełna sensu i właściwie tłumaczy abstrakcję — w ogóle. [...] Co mogę napisać o tych obrazach może być łatwo nazwane moją osobistą fantasmagorią. Cudowne zestawienie tępego żółtego złota z brązem, białością i ciemnym niemal czarnym brązem w obrazie

${ }^{289}$ S. Zahorska, Wystawy londyńskie, W $1960 \mathrm{nr}$ 8(725), s. 3 - tam reprodukcja pracy C. Eprila Portret wtasny.

${ }^{290}$ (A. M.), Zemsta Matejki, DPDŻ 10.12.1959, s. 3.

${ }^{291}$ Odczyty i wystawy, TP $1959 \mathrm{nr} 43$, s. 7.

${ }^{292}$ AE, HN, Drian, Paintings by Ulrico Schettini [zaproszenie na wystawę].

${ }^{293}$ Ogłoszenie, OT 1959 nr 61(111), s. 8; (A. M.), „Grupa 49” w Galerii Grabowskiego, DPDŻ 23.12.1959, s. 7 - tam zdjęcie M. Grabowskiego z artystami; 10-lecie „Grupy 49” w Galerii Grabowskiego, Horyzonty 1960 nr 44, s. 67-68; J. W. Sienkiewicz, Polskie galerie sztuki w Londynie, s. 281.

${ }^{294}$ Galeria Grabowskiego. Grupa 49, OT. Dodatek Ilustrowany $1960 \mathrm{nr} 62$, s. d.

${ }^{295}$ Group forty-nine. Tenth Anniversary, London 1959, London 1959. 
Aleksandra Wernera, zestawienie bloków jakby wyciosanych z kamienia na tle żółtozłotego nieograniczonego tła, to dla mnie niesłychanie sugestywna propozycja pustynno-parna, tajemniczo ciężka, jakby ciężarna w fantastyczne możliwości; Marian Kościałkowski nie daje nawet pola do takich ,rzeczowych” marzeń. Buduje wizje czarno-brązowe, czerwonobrązowe, tak systematycznie i dokładnie odważone, że działają jak matematyczna wizja nieznanych światów, są pięknem samym w sobie nawet jeśli nigdzie nie istnieją i istnieć nie mogą. Marian Bohusz-Szyszko jest bardziej ,ludzki”, symbolizuje „Ekstazę” w przepływie złoto-białych i jakże bogatych kolorów i tonów, lub „Troskę” ciemnoniebieską i żółtą, albo przeskakuje do martwej natury uderzającej siłą życia i radości. Janina Baranowska po prostu czaruje i porywa: taka lekkość i puszystość kolorów białych, różowych, szarych (gdzieniegdzie czarny akcent), jakby wspomnienia wszystkich nieb skupiły się miłośnie na jednym płótnie. Niemal wszyscy coś mówią, coś dają — galeria, w której nie ma ani jednego wizerunku, portretu, w której niewiele tylko jest „,rzeczy”, jest pełna życia, gwaru, wspomnień, przewalają się pory roku, światła, mosty, dachy, rybacy, żagle w odcieleśnionych skondensowanych symbolach. Na straży stoi (niewielki) projekt hieratycznego portalu Andrzeja Bobrowskiego. Jeśli nie wszyscy abstrakcjoniści polscy, a nawet jeśli nie wszyscy członkowie Grupy 49 wniknęli w tajemne źródła abstrakcyjnej twórczości, to i tak zdumiewające jest, że polskie malarstwo abstrakcyjne emigracji wnika głębiej od innych w jedyny sens, który się w abstrakcji kryje i umie go wyrazić ${ }^{296}$.

\section{$Z$ recenzji Stanisława Kowalskiego:}

Wystawa, aczkolwiek — jak już zaznaczyliśmy na wstępie — daje tylko skromne wycinki twórczości biorących w niej udział artystów, świadczy o dużej aktywności artystycznej Grupy 49 i o współbrzmieniu jej z głównym nurtem współczesnej sztuki. Widoczne tu i ówdzie potknięcia i pomyłki w niczym tego faktu nie podważają. W dziesięciolecie działalności życzymy Grupie 49 dalszych dziesiątek lat najwyższych osiągnięć w jej twórczym wysiłku ${ }^{297}$.

Zima, Tate Gallery, Londyn

Wystawa rzeźby Jacquesa Lipschitza, pochodzącego z Wileńszczyzny rzeźbiarza polsko-żydowskiego, mieszkającego w Ameryce.

Wydaje się, że w stopniowym procesie poznawania człowieka, Lipschitz zbliżył się do Boga. A człowiek u niego przedstawiony jest zawsze w ciężkim zmaganiu z przeznaczeniem; gotujący się do skoku, czy też mozolnie prący pod wiatr. [...] A wszystko pełne spętanej energii; kontur gniewnie pofałdowany, kształty skręcone niecierpliwością, jak zrywające się nawałnice. Nawet puste przestrzenie - pozostałość strukturalnej ekonomii kubizmu - czynią wrażenie wirów spowodowanych odśrodkową siłą rozpędzonych form. Lipschitz wyszedł daleko poza świat swej generacji i dzisiaj z perspektywy blisko 50 lat twórczości sztuka jego stanowi nieprzerwany łańcuch pogłębień odkrywczych, którego każde ogniwo jest okrzykiem wykutym z bronzie. Styl jego rozwijał się zwolna, bez nagłych skrętów i niebezpiecznych wiraży, aż osiągnął przekonywującą świadomość pewności plastycznej prawdy ${ }^{298}$.

Grudzień, Stowarzyszenie Fotografików Polskich - Polska YMCA, 46/47 Kensington Gdns Square, Londyn

${ }^{296}$ S. Zahorska, Wystawy londyńskie, W 1960 nr 8(725), s. 3.

${ }^{297}$ S. Kowalski, Jubileusz Grupy 49, Kontynenty-Nowy Merkuriusz 1960 nr 13, s. 22.

${ }^{298}$ S. Frenkiel, Prometeusz Rozkuty, Merkuriusz Polski - Życie Akademickie — Młoda Sztuka, 1960 nr 1(116), s. 10. 
SFP wydało pierwszy nr „Biuletynu” - 32 strony dużego formatu, 3 fotografie (Baziuka, Wondraczka i Franka) ${ }^{299}$.

Grudzień[?], Szkoła Polskiej Macierzy Szkolnej, Devonia Rd., Londyn Wystawa rysunków uczniów Zasadniczej Szkoły Kolejowej z Pruszkowa, zorganizowana przez Ośrodek Metodyczny Kształcenia Zawodowego w Warszawie i przywieziona do Wielkiej Brytanii z inicjatywy Polskiej Sekcji Ministry of Education. W październiku wystawa pokazywana była w dwóch szkołach angielskich: St. Bernard's Stepney Sec. School oraz Manorside Finchley Sec. Girls' School. Na koniec pokazano wystawę nauczycielom polskich szkół sobotnich w czasie dorocznej konferencji w szkole PMS na Devonia ${ }^{300}$.

13 grudnia, Polska YMCA, 46/47 Kensington Gdns Square, Londyn Wycieczka artystyczna Polskiej YMCA do Tate Gallery z prelekcją Mariana Bohusza-Szyszko na temat nowości w zbiorach Tate ${ }^{301}$.

20 grudnia, Polska YMCA, 46/47 Kensington Gdns Square, Londyn Otwarcie wystawy Szkoły Malarstwa Sztalugowego Społeczności Akademickiej $\mathrm{USB}^{302}$

20-27 grudnia, „Wiadomości”, Londyn

W świątecznym numerze „Wiadomości” ukazało się wiele, bogato ilustrowanych, tekstów o sztuce. Wśród nich esej Stanisława Frenkla pt. Poczatki baroku ${ }^{303}$, recenzja Stefanii Niekraszowej Tematy muzyczne w sztuce polskiej ${ }^{304}$, szkic Zofii Kozarynowej Modigliani i Zborowski ${ }^{305}$ i zbiorowa recenzja londyńskich ekspozycji pióra Stefanii Zahorskiej pt. Wystawy ${ }^{306}$.

27 grudnia, Polska YMCA, 46/47 Kensington Gdns Square, Londyn Wycieczka artystyczna Polskiej YMCA do British Museum z prelekcją Mariana Bohusza-Szyszko „Najważniejsze kultury plastyczne” ${ }^{307}$.

30 grudnia, Polska YMCA, 46/47 Kensington Gdns Square, Londyn

Odczyt Jana Ostrowskiego, redaktora „Dziennika Polskiego i Dziennika Żołnierza”, pt. „Polskie życie kulturalne Londynu w 1959 roku”,308.

B.d., Kościół St. Mary, Swansea

W jednej z nisz odnowionego po zbombardowaniu w czasie II wojny światowej kościoła St Mary, umieszczono figurę kamienną Sw. Edeyrna, wykonaną przez polskiego

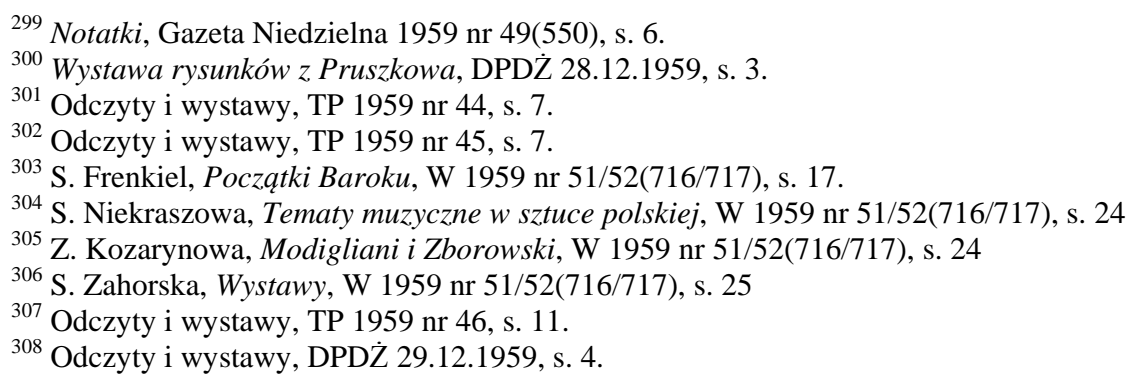


rzeźbiarza Konstantego Woynarowskiego (Wojnarowskiego). Woynarowski, lotnik, ekonomista, zajął się rzeźbą na początku lat 50. i osiadł w Cornwalii ${ }^{309}$.

B.d., Fulham Rd., Londyn

Jan Kępiński otworzył własne studio projektowe, w którym aż do połowy lat 80. jako asystent pracować będzie Mieczysław Malski. W nowym studio Kępiński zmienia materiał, w którym pracuje. Miejsce czystej papieroplastyki zastąpił w realizacjach studia cienką blachą aluminiową, a związek z brytyjskim Central Office of Information zapewnił firmie zamówienia na wykonywane $\mathrm{z}$ metalu herby i heraldyczne elementy zdobiące pawilony międzynarodowych targów od Lagos i Akry po Hongkong, Bogotę, Filadelfię, Mediolan i Poznań ${ }^{310}$.

B.d., Szkocja

British Arts Council Traveling Exhibition in Scotland, z udziałem Halimy Nałęcz ${ }^{311}$.

B.d., Galerie Creuze, Paryż

Wystawa zorganizowana przez Free Painters Group pt. 24 Young British Painters z udziałem Halimy Nałęcz ${ }^{312}$.

\footnotetext{
${ }^{309}$ Rzeźbiarz wizjoner, DPDŻ 23.06.1959, s. 8 .

${ }^{310}$ A. Borkowski, O papieroplastyce polskiej, [w:] Sztuka polska w Wielkiej Brytanii 1940_ 2000 , s. 53.

${ }^{311}$ Halima Nalecz. Paintings and Drawings, 7th-24th October 1959 [katalog wystawy], London: New Vision Centre Gallery, 1959, s. [3]; , The Four Seasons” recent paintings by Halima Nalecz [katalog wystawy] Drian Galleries, February 24th to March 14th, 1970, London 1970, s. [3].

${ }^{312}$ Halima Nalecz. Paintings and Drawings, 7th-24th October 1959, s. [3]; „,The Four Seasons"..., s. [4].
} 